Gracie Luiza da Silva

\title{
ESTUDO DA AÇÃO INIBITÓRIA DA QUITOSANA SOBRE OS ENTEROPATÓGENOS: Salmonella enterica, Shigella sonnei e Escherichia coli EPEC
}

\begin{abstract}
Dissertação apresentada ao Programa de Pós-graduação Interunidades em Bioengenharia - Escola de Engenharia de São Carlos/ Faculdade de Medicina de Ribeirão Preto/ Instituto de Química de São Carlos - da Universidade de São Paulo para obtenção do título de Mestre em Bioengenharia.
\end{abstract}

Orientadora: Profa. Dr. Ana Maria de Guzzi Plepis

SÃO CARLOS

2005 


\section{DEDICATÓRIA}

A DEUS sempre presente, pela graça da vida, por me fazer aprendiz para lutar pelos meus ideais e acreditar na vida.

Aos meus pais, Leonino e Lázara, pela formação, amor, dedicação, por todas as oportunidades e exemplo de vida.

Ao meu namorado Alfredo, pela compreensão, paciência, carinho e amor.

Ao meu amigo André pela dedicação, companheirismo, incentivo, carinho e ajuda. 



\section{AGRADECIMENTOS}

À Profa. Dr. Ana Maria de Guzzi Plepis, pela confiança, orientação, dedicação, paciência, compreensão e amizade.

Ao Prof. Dr. José Carlos Pereira, por toda ajuda, dedicação, pelo exemplo marcante de profissional e ser humano.

Ao Centro universitário Barão de Mauá pelo espaço cedido para a realização deste trabalho.

Aos amigos e técnicos de laboratório do Centro Universitário Barão de Mauá de Ribeirão Preto, Aristeu Costa e Márcio Rodrigues, pela dedicação, amizade e pelo auxílio no preparo e na esterilização do material utilizado.

Aos Profs. Drs. Orivaldo Lopes Silva, Parê pela amizade e ajuda.

Aos funcionários da Bioengenharia de São Carlos, em especial à Janete Ferreira Rodrigues dos Santos, secretária do Programa pela atenção, dedicação e carinho.

Á Dra. Virgínia C.A. Martins, técnica do laboratório de Bioquímica e Biomateriais do Instituto de Química de São Carlos, por toda ajuda e carinho.

Ao amigo Doutorando André Pitondo da Silva pela doação das amostras dos enteropatógenos e todo carinho e dedicação.

Ao Doutorando José Fernando Dagnone Figueiredo pela caracterização da solução de quitosana derivada de lula.

À Rafaela Basso Montoro pela caracterização da solução de quitosana derivada de camarão.

Aos Profs. César Augusto Terçariol e Roberto Luís Barini por toda ajuda, preciosos ensinamentos, paciência, dedicação, carinho e amizade.

À amiga Andrezza Furquim da Cruz carinhosamente sempre presente e dedicada a ajudar.

Às irmãs Rosemary e Luciana de Oliveira por toda dedicação.

Ao Prof. Dr. Antônio Manuel Rodrigues Coelho pela ajuda com o abstract, amizade e incentivo.

A todos que de alguma forma colaboraram para a realização deste trabalho, Obrigada!!! 
"Nada neste mundo ultrapassa a grandeza ou a dignidade da pessoa humana.

A vida é uma realidade concreta de um ser que tem a capacidade de amar e de servir a humanidade."

João Paulo II 


\section{RESUMO}

SILVA, G.L. (2006). Estudo da ação inibitória da quitosana sobre os enteropatógenos: Salmonella enterica, Shigella sonnei e Escherichia coli EPEC. Dissertação (Mestrado) - Escola de Engenharia de São Carlos, Faculdade de Medicina de Ribeirão Preto e Instituto de Química de São Carlos, Universidade de São Paulo, São Carlos, 2005.

Este estudo teve por objetivo avaliar a ação inibitória de duas soluções de quitosana através da determinação da Concentração Inibitória Mínima (CIM) e Concentração Bactericida Mínima (CBM) de duas soluções de quitosana de diferentes procedências. A primeira solução de quitosana derivada de camarão, do tipo comercial Fluka, de PM $600.000 \mathrm{~g} / \mathrm{mol}$, G.A. $76 \%$ e a segunda solução de quitosana derivada de lula, de PM: $10^{7} \mathrm{~g} / \mathrm{mol}$ e G.A.: $83 \%$. As duas soluções foram ajustadas ao $\mathrm{pH} 5,0$ e na concentração de $0,5 \%$ em solução acética a $1 \%$. A melhor atividade antimicrobiana da quitosana ocorre em $\mathrm{pH}$ igual ou menor que cinco e ela sofre precipitação em pH superiores a 6,5. Estas duas características foram determinantes na escolha do $\mathrm{pH}$ utilizado no teste da CIM. Para confirmar que a inibição do crescimento dos enteropatógenos ocorreu pela ação da quitosana e não pelo $\mathrm{pH}$ ácido dos meios, vários testes foram realizados. A Avaliação do crescimento dos enteropatógenos em ágar MacConkey, pH 5,0 (ótimo para quitosana) e 7,4(ótimo para o cultivo das bactérias utilizadas), o inóculo de cada bactéria foi preparado segundo o tubo 0,5 de Mc Farland (controle positivo), e a avaliação foi repetida utilizando o inóculo diluído 1:1000 para contagem do número de colônias, e não apresentaram diferenças significativas. Para confirmar estes dados foram realizados os controles negativos das duas soluções de quitosana e do meio de cultura MacConkey em pH 5,0 e 7,4, incubados a $37^{\circ} \mathrm{C}$ e lidos por 72 horas, sem qualquer alteração. A Avaliação da reação de precipitação foi feita em caldo Müeller Hinton em pH 4,0; 5,0; 6,0; 7,0 e 8,0 para as duas soluções de quitosana $(\mathrm{v} / \mathrm{v})$, incubados a $37^{\circ} \mathrm{C}$ e lidos por 72 horas. A Avaliação da CIM das duas soluções de quitosana para os enteropatógenos foi realizada por diluição seriada e os inóculos comparados ao tubo 0,5 de Mc Farland, sendo $10 \mu \mathrm{L}$ da suspensão bacteriana acrescida a cada tubo, incubados a $37^{\circ} \mathrm{C}$ por 24 horas. $\mathrm{A}$ leitura da ausência de turvação visível caracterizou a CIM. Todos os tubos que não apresentaram turvação visível foram plaqueados em ágar MacConkey, em pH 7,4 e incubados a $37^{\circ} \mathrm{C}$ por 24horas para determinação da CBM, a qual foi determinada pela menor concentração capaz de causar morte total da população dos enteropatógenos. Todas as técnicas foram realizadas em triplicata para confirmação dos resultados.

Palavras chaves: Quitosana, Enteropatógenos e Ação inibitória. 


\section{ABSTRACT}

SILVA, G.L. (2006). Inhibitory Action of chitosan in enteropathogens Salmonella enterica, Shigella sonnei and Escherichia coli EPEC. Dissertation (Master Degree) - Escola de Engenharia de São Carlos, Faculdade de Medicina de Ribeirão Preto and Instituto de Química de São Carlos, Universidade de São Paulo, São Carlos, 2005.

The aim of this study was to evaluate the inhibitory action of chitosan solutions derived from shrimp (Fluka commercial type, MW $600.000 \mathrm{~g} / \mathrm{mol}$, Acetylation degree of $76 \%$ ) and squid (MW $10^{7} \mathrm{~g} / \mathrm{mol}$, Acetylation degree of 83\%) through determination of Minimum Inhibitory Concentration (MIC) and Minimum Bactericidal Concentration (MBC) against enteropathogens: Salmonella enterica, Shigella sonnei and Escherichia coli EPEC. Those solutions were set to $\mathrm{pH} 5,0$ and a $0,5 \%$ concentration in a $1 \%$ acetic acid solution. The best antimicrobial activity of chitosan occurs in $\mathrm{pH}$ less than or equal to 5,0 and it shows precipitation in $\mathrm{pH}$ greater than 6,5. Those features were decisive to choose the $\mathrm{pH}$ used in the MIC test. In order to confirm that the growth inhibition of enteropathogens occurred by the action of chitosan and not for the acid $\mathrm{pH}$ of the environments, growth evaluation tests of enteropathogens were accomplished in MacConkey agar, $\mathrm{pH}$ 5,0 (excellent for chitosan) and $\mathrm{pH}$ 7,4 (excellent for culture of used bacteria). The inoculum of each bacterium was prepared comparing with the 0,5 tube of McFarland (positive control) and the evaluation was repeated using the inoculum diluted in a salt solution 1:1000 to count the number of colonies, which did not show significant differences. The reaction evaluation of precipitation of chitosan was done in Müeller Hinton broth with $\mathrm{pH}$ ranging 4,0 -8,0 for both solutions of chitosan $(\mathrm{v} / \mathrm{v})$, which were incubated at $37^{\circ} \mathrm{C}$ and read for 72 hours. The MIC evaluation for both solutions of chitosan for the enteropathogens was done by serial dilution and the inocula were compared to the 0,5 tube of McFarland, adding $10 \mu \mathrm{L}$ of bacterial suspension to each tube, which were incubated at $37^{\circ} \mathrm{C}$ for 24 hours. The MIC was distinguished by the absence of visible turbidity. Each tube that did not

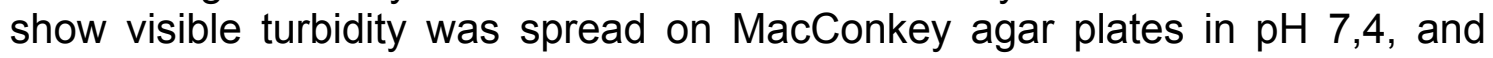
incubated at $37^{\circ} \mathrm{C}$ for 24 hours to find the MBC, which was determined by the smallest concentration able to cause total death to the enteropathogen population. In both cases, the solutions of chitosan presented a high antimicrobial activity against the enteropathogens Salmonella enterica and Escherichia coli EPEC. However, the higher antimicrobial activity was observed in the enteropathogen Shigella sonnei.

Key words: Chitosan, Enteropathogenesis and Inhibitory action. 


\section{LISTAS DE FIGURAS}

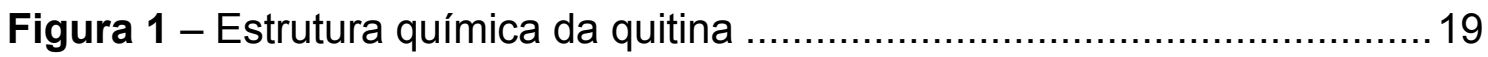

Figura 2 - Estrutura química da quitosana ............................................ 19

Figura 3 - Representação da estrutura química da quitosana, onde $x$ representa o grau de acetilação................................................. 19

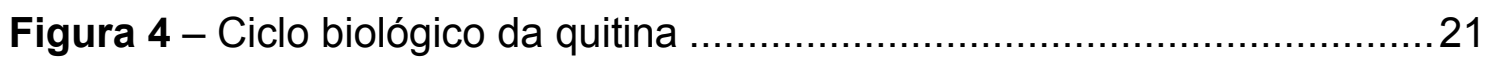

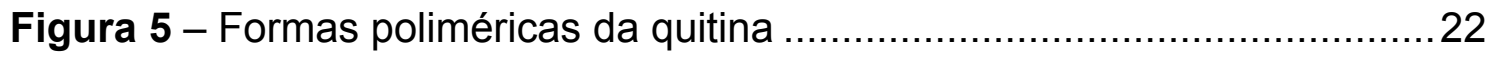

Figura 6 - Esquema do processo de obtenção de quitina e quitosana ..............23

Figura 7 - Representação esquemática de uma enterobacteriácea .................31

Figura 8 - Composição da microbiota do aparelho digestivo do homem..........33

Figura 9 - Microscopia de transmissão, amostra de EPEC com adesão em forma de pedestais e conseqüente destruição das microvilosidades

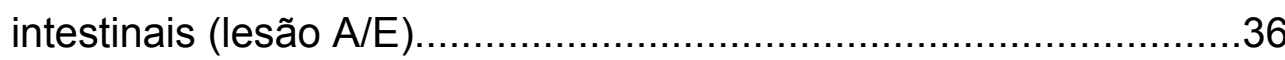

Figura 10 - Mecanismo de patogenicidade da Shigella sp .............................39

Figura 11 - Mecanismo de patogenicidade da Salmonella sp .......................42

Figura 12 - Cultura de 24horas de S.enterica em ágar SS .............................50

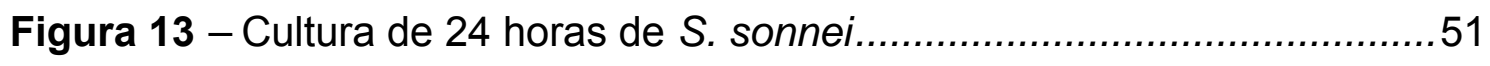

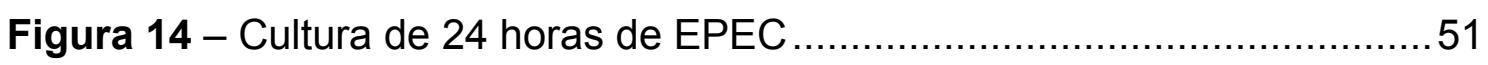

Figura 15 - Recuperação metabólica e obtenção de cultura de 24 horas das amostras dos enteropatógenos provenientes do Banco de Amostras (USP - Ribeirão Preto).

Figura 16 - Avaliação do crescimento dos enteropatógenos em meio MC em pH 5,0 e 7,4.

Figura 17 - Esquema da reação de precipitação da quitosana em pH acima de 6,5 .

Figura 18 - Distribuição do meio MHB nos tubos de ensaio para a avaliação de CIM 56

Figura 19 - Acréscimo da solução de quitosana pH 5,0 seriada 57

Figura 20 - Preparo e acréscimo da suspensão bacteriana 58

Figura 21 - Esquema da técnica para avaliação da Concentração bactericida mímina (CBM) das soluções de quitosana sobre os enteropatógenos

Figura 22.A - Salmonella enterica em ágar SS 
Figura 22.B - Shigella sonnei em ágar SS 62

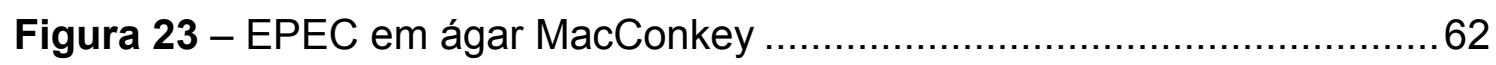

Figura 24.A - Controle negativo do meio ágar MC em pH 5,0 .......................64

Figura 24.B - Controle do meio ágar $\mathrm{MC}$ em pH 7,4 ..................................64

Figura 25.A - Controle negativo da solução de quitosana derivada de camarão em pH 5,0

Figura 25.B - Controle negativo da solução de quitosana derivada de camarão em $\mathrm{pH} 7,4$ 64

Figura 26.A - Controle negativo da solução de quitosana derivada de lula em $\mathrm{pH} 5,0$ 65

Figura 26.B - Controle negativo da solução de quitosana derivada de lula em $\mathrm{pH} 7,4$ 65

Figura 27.A - Controle positivo de S. enterica em ágar $\mathrm{MC}$ em pH 5,0. 66

Figura 27.B - Controle positivo de S.enterica enterica em ágar MC em $\mathrm{pH} 7,4$ 66

Figura 28.A - Controle positivo de $S$. sonnei em ágar $\mathrm{MC}$ em pH 5,0 66

Figura 28.B - Controle positivo de $S$. sonnei em ágar $\mathrm{MC}$ em pH 7,4 ............66

Figura 29.A - Controle positivo de EPEC em ágar MC em pH 5,0 ….............67

Figura 29.B - Controle positivo de EPEC em ágar $\mathrm{MC}$ em pH 7,4 . 67

Figura 30.A - Contagem do número de colônias de S.enterica em ágar MC, $\mathrm{pH} 5,0$ 68

Figura 30.B - Contagem do número de colônias de S.enterica em ágar MC, $\mathrm{pH} 7,4$ 68

Figura 31.A - Contagem do número de colônias de S.sonnei em ágar MC, $\mathrm{pH} 5,0$

Figura 31.B - Contagem do número de colônias de S.sonnei em ágar MC, $\mathrm{pH} 7,4$

Figura 32.A - Contagem do número de colônias de EPEC em ágar MC, $\mathrm{pH} 5,0$ 69

Figura 32.B - Contagem do número de colônias de EPEC em ágar MC, $\mathrm{pH} 7,4$ 69

Figura 33.A - Série de quitosana derivada de camarão em meio $\mathrm{MHB}$ em pH 4,$0 ; 5,0 ; 6,0 ; 7,0$ e 8,0 
Figura 33.B Série de quitosana derivada de lula em meio $\mathrm{MHB}$ em $\mathrm{pH}$

4,$0 ; 5,0 ; 6,0 ; 7,0$ e 8,0

Figura 34.A - Série de quitosana derivada de camarão em meio $\mathrm{MHB}$ em pH

4,$0 ; 5,0 ; 6,0 ; 7,0$ e 8,0, após $24 \mathrm{~h}$ de incubação/ $37^{\circ} \mathrm{C}$

Figura 34.B - Série de quitosana derivada de lula em meio $\mathrm{MHB}$ em $\mathrm{pH}$

4,$0 ; 5,0 ; 6,0 ; 7,0$ e 8,0, após $24 \mathrm{~h}$ de incubação/ $37^{\circ} \mathrm{C}$ 72

Figura 35 - Concentração Inibitória Mínima (CIM) de quitosana derivada de camarão para S. enterica 73

Figura 36 - Concentração Inibitória Mínima (CIM) de quitosana derivada de lula para S. enterica

Figura 37 - Concentração Inibitória Mínima (CIM) de quitosana derivada de camarão para S. sonnei

Figura 38 - Concentração Inibitória Mínima (CIM) de quitosana derivada de lula para S. sonnei 76

Figura 39 - Concentração Inibitória Mínima (CIM) de quitosana derivada de camarão para EPEC

Figura 40 - Concentração Inibitória Mínima (CIM) de quitosana derivada de lula para EPEC

Figura 41 - Concentração Bactericida Mínima (CBM) das soluções de quitosana derivadas de camarão e de lula para S. enterica 79

Figura 42 - Concentração Bactericida Mínima (CBM) de quitosana derivada de camarão para S.sonnei 80

Figura 43 - Concentração Bactericida Mínima (CBM) de quitosana derivada de lula para S.sonnei

Figura 44 - Concentração Bactericida Mínima (CBM) das soluções de quitosana derivadas de camarão e de lula para EPEC. 82

Figura 45 - Gráfico das CIM e CBM das soluções de quitosana derivadas de camarão e de lula para os enteropatógenos estudados .84 


\section{LISTAS DE TABELAS}

TABELA 1. Porcentagem de quitina em alguns organismos

TABELA 2. Diferentes aplicações da quitosana nas áreas: Industrial e Saúde/ Nutricional ........................................................ 25

TABELA 3. Esquema Abreviado de Kauffman \& White .............................. 41

TABELA 4. Composição do ágar MacConkey .......................................... 47

TABELA 5. Composição do ágar SS ................................................... 48

TABELA 6. Composição do Brain Heart Infusion (BHI) ...........................48

TABELA 7. Composição do meio Müeller Hinton.....................................49

TABELA 8. Tubo 0,5 da escala McFarland ......................................49

TABELA 9. Diluições e concentrações aproximadas das soluções de quitosana 59

TABELA 10. Número de unidades formadoras de colônias (UFC) dos enteropatógenos em ágar MacConkey em pH 5,0 e 7,4 70

TABELA 11. CIM e CBM das soluções de quitosana derivadas de camarão e de lula para os enteropatógenos 
A/E Destruição de microvilosidades (Lesão attaching-and-effacing)

AMPc Adenosina monofosfato cíclica

BFP Fímbria Bundle-forming-pilus

BHI Brain Heart Infusion

CBM Concentração Bactericida Mínima

CIM Concentração Inibitória Mínima

CFA Fator antigênico de colonização

$\mathrm{Da}$ dalton

DAEC Escherichia coli com padrão de adesão difusa

DNA Ácido desoxinucleíco

DSC calorimetria exploratória diferencial

DTG termogravimetria diferencial

EAEC Escherichia coli Enteroagregativa

EAF Plasmídio - EPEC Adherence Factor

EHEC Escherichia coli Enterohemorrágica

EIEC Escherichia coli Enteroinvasora

EPEC Escherichia coli Enteropatogênica

ETEC Escherichia coli Enterotoxigênica

FATOR R Fator de resistência

FTIR Espectrometria de absorção no infravermelho

GD Grau de desacetilação

GMP c Guanosina monofosfato cíclica

$H^{1} R M N$ ressonância magnética nuclear próton

SHU Síndrome hemolítica urêmica

IgA Imunoglobulina A

IV Infra vermelho

Kda Kilodalton

LA Adesão localizada

LAL Adesão localizada-like

LPS Lipopolissacarídeo

LT heat labile (termolábil) 


\begin{tabular}{|c|c|}
\hline MBC & concentração bactericida mínima \\
\hline MC & ágar MacConkey \\
\hline MEV & microscopia eletrônica de varredura \\
\hline MIC & concentração inibitória mínima \\
\hline MHB & caldo Müeller Hinton \\
\hline mL.min ${ }^{-1}$ & milílitro por minuto \\
\hline mRNA & Ácido ribonucléico ( mensageiro) \\
\hline NAG & $\mathrm{N}$-acetil- glicosamina \\
\hline NAM & Ácido N-acetil murâmico \\
\hline $\mathrm{NHCOCH}_{3}$ & grupamento acetoamido \\
\hline PILLI & Pêlos \\
\hline PMN & polimorfonuclear \\
\hline PPM & parte por milhão \\
\hline PVC & policloreto de vinila \\
\hline Qc & quitosana derivada de camarão \\
\hline QI & quitosana derivada de lula \\
\hline RNA & Ácido ribonucléico \\
\hline ss & ágar SS para Salmonella e Shigella \\
\hline ST & heat stable (termoestável) \\
\hline $\mathrm{v} / \mathbf{v}$ & volume por volume \\
\hline
\end{tabular}




\section{SUMÁRIO}

DEDICATÓRIA

AGRADECIMENTOS

LISTA DE ABREVIATURAS E SIGLAS

LISTA DE FIGURAS

LISTA DE TABELAS

RESUMO

ABSTRACT

1 - INTRODUÇÃO

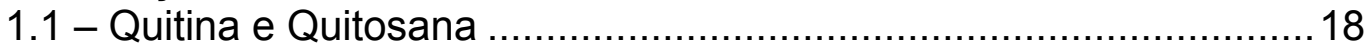

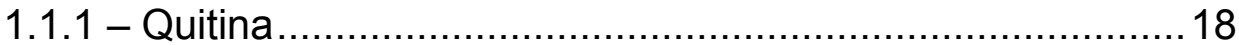

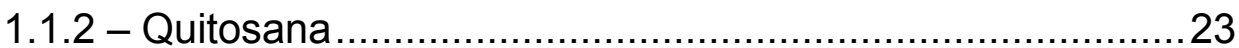

1.1.2.1 - Efeito Antimicrobiano da Quitosana .................26

1.2 - Enteropatógenos .................................................................. 30

1.2.1 - Estruturas da célula bacteriana Gram negativa ...............31

1.2.2 - Ação dos enteropatógenos nas infecções intestinais........32

1.2.3 - Mecanismos de patogenicidade dos enteropatógenos ....34

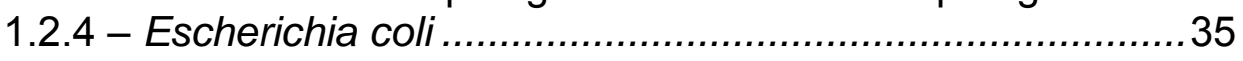

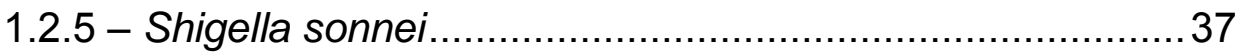

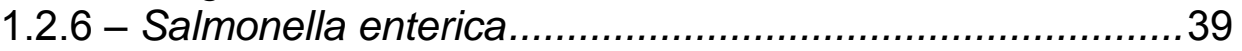

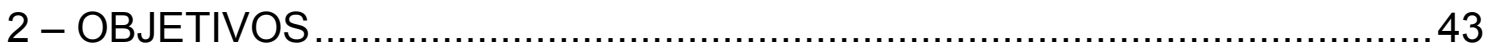

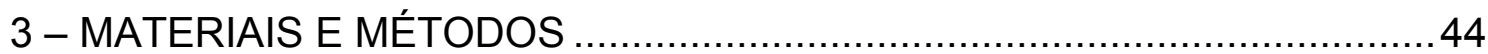

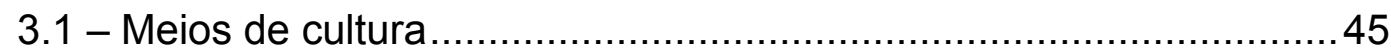

3.1.1 - Meios de cultura utilizados ........................................46

3.1.1.1 - Ágar MacConkey .............................................. 46

3.1.1.2 - Ágar SS para Salmonella e Shigella ...................46 46

3.1.1.3 - B.H.I. (Brain Heart Infusion) ……………......... 47

3.1.1.4 - Ágar Müeller Hinton......................................... 48

3.1.1.5 - Tubo 0,5 da escala de Mc Farland ....................48 48

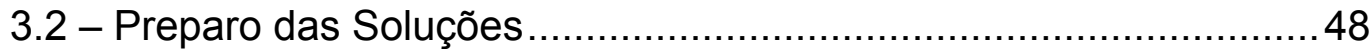

3.3 - Obtenção dos Enteropatógenos ...............................................49

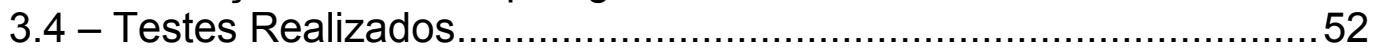

3.4.1 - Avaliação do crescimento dos Enteropatógenos em estudo em meio M C em pH 5,0 e 7,4 ..........................52

3.4.2 - Avaliação da Reação de Precipitação das Soluções de Quitosana derivada de camarão e de lula em pH superiores a 6,5

3.4.3 - Avaliação da Concentração Inibitória Mínima de Quitosana derivada de camarão e de lula pelo método da diluição para os Enteropatógenos .............................................56

3.4.4 - Avaliação da Concentração Bactericida Mínima de Quitosana derivada de camarão e de lula pelo método qualitativo

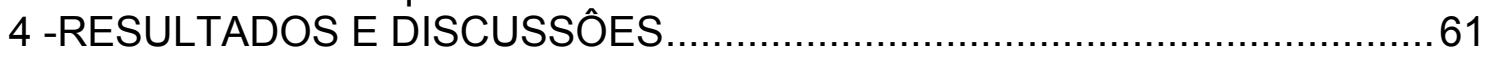

4.1 - Preparo das Soluções de Quitosana............................................61

4.2 - Obtenção dos patógenos ..........................................................61

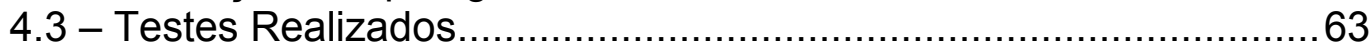

4.3.1 - Avaliação do crescimento dos Enteropatógenos em estudo 
4.3.1.1 - Avaliação do controle negativo do meio de cultura MC e das soluções de Quitosana derivadas de camarão e de lula nas faixas de pH 5,0 e 7,4 ...63

4.3.1.2 - Avaliação do controle positivo do crescimento dos Enteropatógenos em estudo meio $\mathrm{MC}$ em $\mathrm{pH} 5,0$ e 7,4

4.3.2 - Avaliação de UFC dos Enteropatógenos em MC em $\mathrm{pH} 5,0$ e 7,4 .

4.3.3 - Observação da reação de precipitação da Quitosana em $\mathrm{pH}$ superior a 6,5 .

4.3.4 - Avaliação da Concentração Inibitória Mínima de Quitosana derivada de camarão lula pelo Método Quantitativo pelos Enteropatógenos em estudo

4.3.4.1 - Concentração Inibitória Mínima da Solução de Quitosana derivada de camarão para S enterica 72

4.3.4.2 - Concentração Inibitória Mínima da Solução de Quitosana derivada de lula para S. enterica ........ 73

4.3.4.3 - Concentração Inibitória Mínima da Solução de Quitosana derivada de camarão para S sonnei ... 74

4.3.4.4 - Concentração Inibitória Mínima da Solução de Quitosana derivada de lula para S. sonnei...........76

4.3.4.5 - Concentração Inibitória Mínima da Solução de Quitosana derivada de camarão para EPEC …...77

4.3.4.6 - Concentração Inibitória Mínima da Solução de Quitosana derivada de lula para EPEC.

4.3.5 - Avaliação da Concentração Bactericida Mínima de derivada de camarão e lula através do plaqueamento ou subcultura Quitosana dos tubos que não apresentaram turvação visível

4.3.5.1 - Concentração Bactericida Mínima das Soluções de Quitosana derivadas de camarão e de lula para Salmonella enterica

4.3.5.2 - Concentração Bactericida Mínima das soluções de Quitosana derivada de camarão para S. sonnei .. 80

4.3.5.3 - Concentração Bactericida Mínima das soluções de Quitosana derivada de lula para S. sonnei. 80

4.3.5.4 - Concentração Bactericida Mínima das Soluções de Quitosana derivadas de camarão e de lula para EPEC

4.4 - Tabela dos resultados da CIM e da CBM das Soluções de Quitosana derivada de camarão e de lula para os enteropatógenos em estudo

4.5 - Gráfico ilustrativo da CIM e da CBM das Soluções de Quitosana derivada de camarão e de lula para os enteropatógenos em estudo 


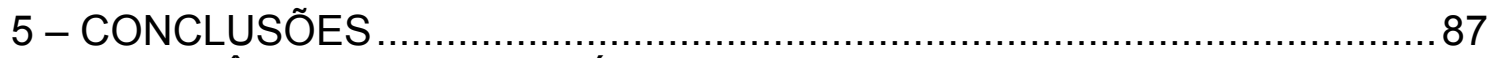

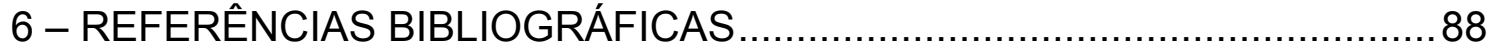

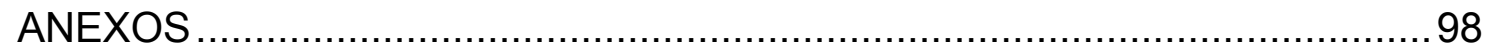




\section{INTRODUÇÃO}

O organismo humano é acometido por várias infecções e doenças causadas por microrganismos e dentre elas, a maior prevalência é dada pelas infecções intestinais (BERN, C. et al., 1992; GUERRANT, R.L. et al., 1990). Aproximadamente 3,3 milhões de crianças menores de cinco anos, acometidas por estas infecções chegam a óbito todo ano (BERN, C. et al., 1992).

Os agentes patogênicos responsáveis pelas infecções intestinais, em grande parte são representados por bactérias, pertencentes à família Enterobacteriaceae, a qual tem merecido destaque especial nos últimos tempos por apresentar a maior freqüência de patógenos isolados em Microbiologia Clínica, seja nas infecções gastrointestinais, ou ainda, em outras patologias como meningites, intoxicações alimentares, infecções do trato urinário, infecções nosocomiais. (SILVA, C.H.P.M., 1999). As infecções localizadas mais freqüentes são as das vias urinárias, dos pulmões, do sistema nervoso central, da pele e do tecido subcutâneo (feridas), podendo ficar localizadas ou ainda sofrer bacteremias. (TRABULSI, L.R. et al., 2004).

É importante ressaltar que um grupo desta família faz parte da microbiota intestinal do homem e de outros animais, entretanto tem sido responsável por grandes problemas de saúde em todo o mundo. Este fato se deve a algumas mudanças, por exemplo, a utilização desmedida de antibióticos, responsáveis pela seleção de bactérias multiresistentes (fator $R$ ), conferido principalmente por plasmídios. Temos ainda, a implantação de procedimentos cirúrgicos e regimes terapêuticos que comprometem as defesas do hospedeiro fornecendo novas portas de entrada a tais agentes (SILVA, C.H.P.M., 1999).

Os gêneros de maior expressão desta família de bactérias na região intestinal na população são: Salmonella, Escherichia e Shigella (GOMES, T.A.T. et al., 1996). 
Alguns dados são valiosos, no que tange à patogenicidade desses agentes, podendo variar segundo o período do ano, a localização geográfica, o nível sócio - econômico e a idade dos pacientes (GOMES, T.A.T. et al, 1991).

O processo de transmissão dos enteropatógenos é dado através da via oral-fecal; alimentos mal cozidos, contaminados por água ou pelo solo de cultivo que entrou em contato com fezes; alimentos manuseados por portadores assintomáticos de microrganismos patógenos, pela autocontaminação pelo toque das mãos em materiais contaminados. Isto leva à necessidade de maior rigor no desenvolvimento e execução de medidas de higiene de ordem pessoal e geral, assim como a implantação de medidas de saneamento básico adequado, principalmente nos países subdesenvolvidos [BENEBSON, A.S. (Ed.). (1995)...]

Considerando-se à necessidade da busca de novos recursos terapêuticos, utilizamos a quitosana como agente antimicrobiano, polímero encontrado em abundância na natureza. Composto atóxico, podendo ser aplicado em diferentes formas, há décadas vem despertando interesse industrial, principalmente na área farmacêutica (CAMPANA-FILHO \& DESDBRIĖRES, 2000).

\subsection{QUITINA E QUITOSANA}

\subsubsection{QUITINA}

Quitina é um polissacarídeo de cadeia linear formado por unidades de 2-acetamida-2-deoxi-D-glicopiranose unidas por ligações do tipo $\beta(1 \rightarrow 4)$.

A quitina foi descrita pela primeira vez em 1811, como fungina, pelo professor francês Henri Branconnet. Em 1823 recebeu o nome de quitina, pelo pesquisador Odier, Khitin, do grego que significa carapaça ou caixa protetora.

A quitina apresenta estrutura química muito semelhante à da celulose, fibra vegetal, polímero mais abundante encontrado na natureza, como indicado nas figuras 1 e 2 (SIGNINI, R., 2002). A desacetilação da quitina é dada pela substituição do grupo hidroxila do carbono na posição dois do anel glicopiranosídico pelo grupo acetamida, como apresentado na figura 3 . 


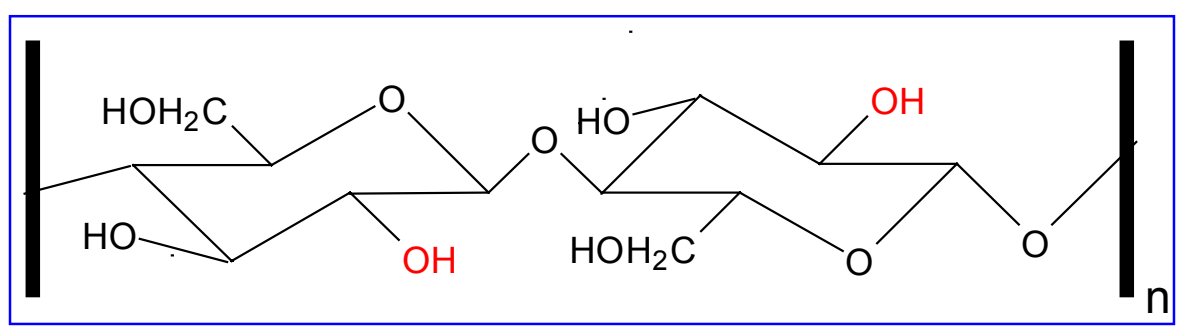

Figura 1 - Estrutura química da Celulose

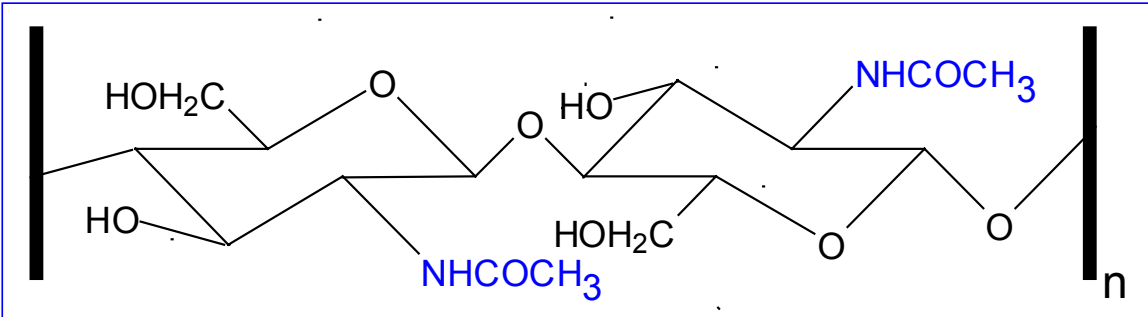

Figura 2 - Estrutura química da Quitina

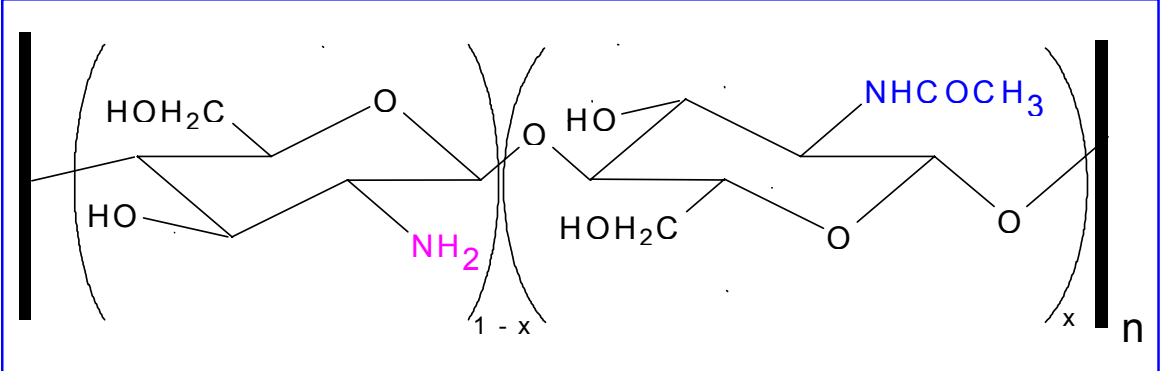

Figura 3 - Representação da estrutura química da quitosana, onde $X$ representa

A quitina é obtida de fontes naturais como crustáceos (caranguejo, camarão, lagosta, siri, lula, krill), insetos (besouros, borboletas, percevejos, formiga, etc.), aracnídeos (escorpião, aranha), fungos e algas (tabela 1). Os laboratórios utilizam os exoesqueletos de crustáceos como a principal fonte fornecedora de quitina.

É realizado tratamento químico para promover a remoção das impurezas presentes nos exoesqueletos. Mesmo não havendo preconização do processamento, três etapas são realizadas, desproteinização, desmineralização e despigmentação (ROBERTS, G.A.F., 1992).

A quitina é praticamente insolúvel em água, ácidos diluídos, álcalis concentrados, assim como na maioria dos solventes orgânicos. Enquanto que 
a quitosana é insolúvel em água, ácidos concentrados, álcalis, álcool e acetona e completamente solúvel em soluções de ácidos orgânicos (ácido acético, ácido fórmico e cítrico), além de ácidos inorgânicos diluídos (ácido clorídrico, ácido nítrico, ácido perclórico ou fosfórico) em pH menor que 6,0 (MATHUR, N.K., NARANG, K.C. 1990).

A quitina e a quitosana são biodegradáveis, sofrem a ação de enzimas hidrolíticas (lisoenzima, quitanase, quitina desacetilase e quitosanase) largamente distribuídas nos tecidos e fluidos corporais de animais e plantas, e também no solo.

\section{Tabela 1 - PORCENTAGEM DE QUITINA EM ALGUNS ORGANISMOS}

\section{Crustáceos:}

Câncer ( carangueijo)..... $72,1 \%$

Callinectes(carangueijo azul). $14,0 \%$

Paralithodes ( carangueijo rei). $10,6 \%$

Pleoroncodes( carangueijo vermelho) $1,8-35,0 \%$

Camarão do Alaska $28,0 \%$

Crangnon(camarão)

Homarus( lagosta) $5,8-69,1 \%$ $60,8-77,0 \%$

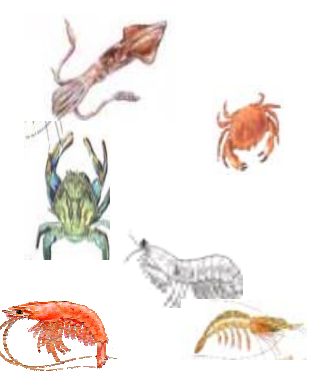

Insetos:

Blattleta (barata). $10,0-35,0 \%$

Coleóptera (besouro) $5,0-15,0 \%$

Díptera ( mosca verdadeira). $.54,8 \%$ Besouro de maio. $16,0 \%$ Pieris( borboleta). $64,0 \%$

Moluscos:

Concha de molusco $6,1 \%$ Krill (Zooplanctum de mares frios).....40,2- 42,0\% Concha de ostra. $3,6 \%$

Fungos:

Mucor roxii. $44,5 \%$

Aspergillus niger. $42,0 \%$

Penicillium chrysogenum. $20,1 \%$
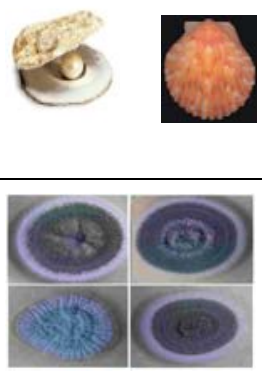

Fonte: CRAVIEIRO, A.A. et al.1999. 
O "ciclo da quitina" impede naturalmente o excesso destes polímeros, assegurando a conservação do ecossistema e meio ambiente.

O processo de degradação biológica da quitina está representado na figura 4 .

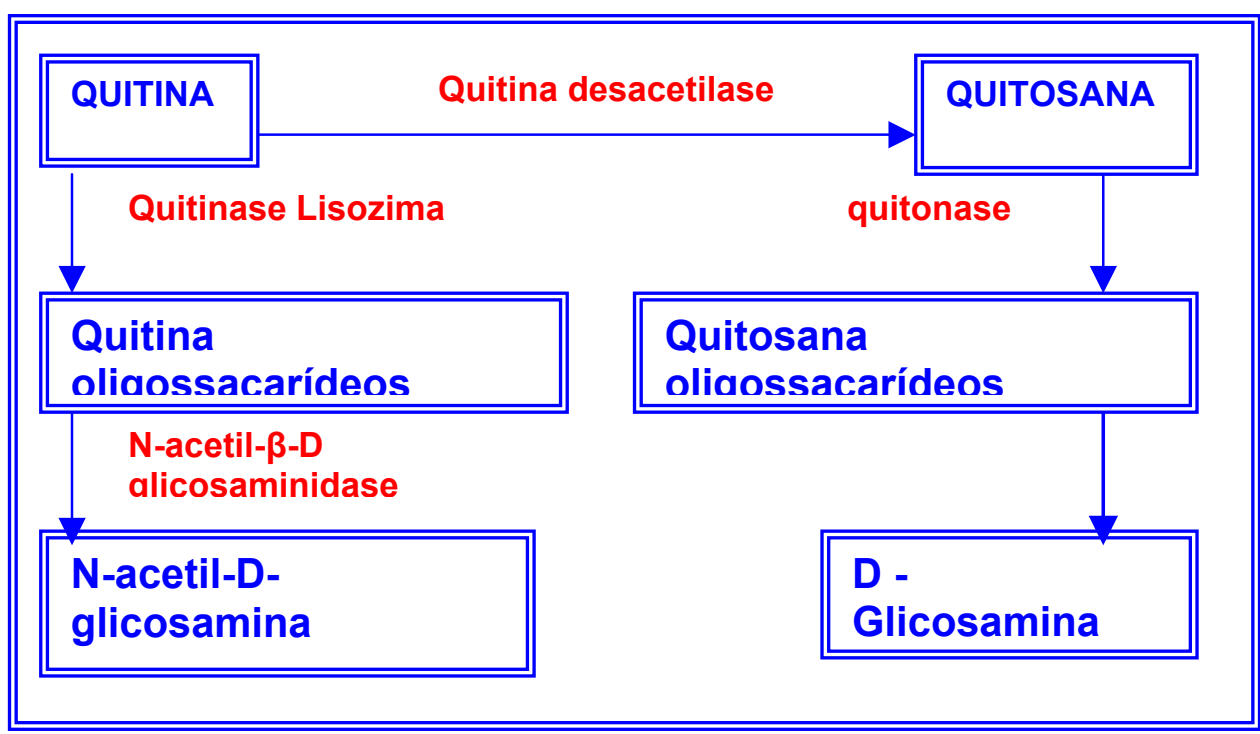

Figura 4 - Ciclo biológico da Quitina Fonte: CRAVIEIRO, A.A. et al. 1999.

A quitina apresenta-se em três formas poliméricas diferenciadas quanto ao arranjo de suas cadeias nas regiões cristalinas, como mostra a figura 5 .

As formas são denominadas como $\alpha, \beta$ e $\gamma$, as quais podem ser evidenciadas através do estudo de difração de raios- $X$.

A forma polimérica a é dominante sobre as demais, além de ser a mais estável e a mais resistente. Esta forma é encontrada em crustáceos, cutícula de artrópodes, parede celular de fungos e em insetos. Geralmente está associada às proteínas e materiais inorgânicos. Apresenta uma disposição alternada de cadeias paralelas e antiparalelas.

As formas poliméricas $\beta$ e $\gamma$ estão relacionadas à flexibilidade e dureza, podem ser convertidas à forma $\alpha$, através de tratamento químico adequado (SIGNINI, R.\& CAMPANA, F., 1998). A forma $\beta$ é encontrada em lula e algas, e apresenta uma disposição de cadeias paralelas, enquanto que a forma $y$ não tem uma caracterização ainda bem definida, embora haja 
sugestões de que tenha duas cadeias paralelas e uma antiparalela (ROBERTS, G.A.F., 1992).

\section{FORMAS POLIMÉRICAS DA QUITINA}

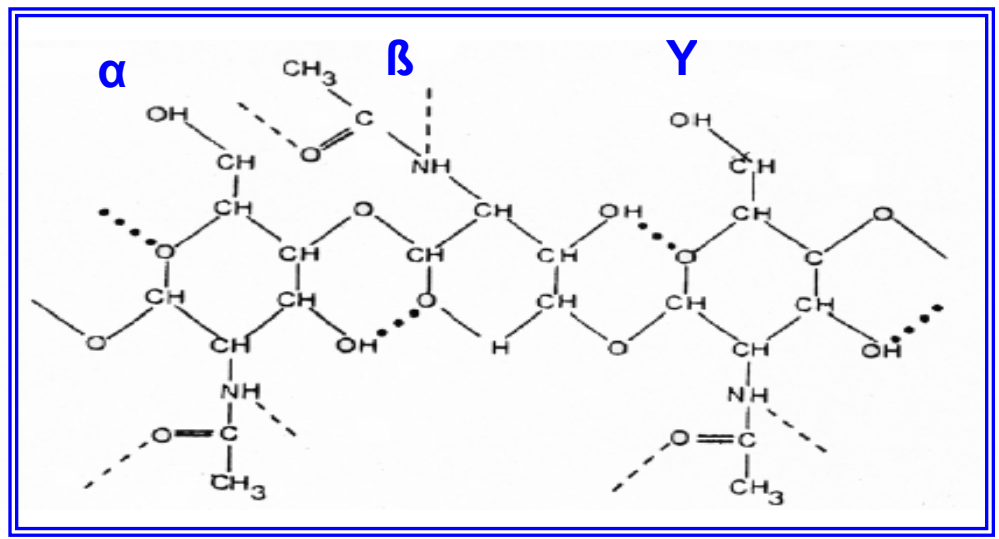

Figura 5 - Estruturas poliméricas da quitina Fonte: Fonte: SPINDLE - BAR, 2002.

O processo de obtenção de quitosana é realizado em várias etapas a partir da moagem dos exoesqueletos de camarão como indicado na figura 6 . A partir da moagem é dado início ao tratamento químico para promover a desproteinização, para isso podem ser utilizadas soluções alcalinas como $\mathrm{NaOH}, \mathrm{Na}_{2} \mathrm{CO}_{3}, \mathrm{KOH}, \mathrm{K}_{2} \mathrm{CO}_{3}, \mathrm{Ca}(\mathrm{OH})_{3}$, entre outras, sendo a de $\mathrm{NaOH}$ a mais utilizada. A segunda etapa ou desmineralização é feita através de tratamento ácido com $\mathrm{HCl}, \mathrm{HNO}_{3}, \mathrm{H}_{2} \mathrm{SO}_{4}$, entre outros, sendo o $\mathrm{HCl}$ o mais utilizado e em concentrações diferentes. Os pigmentos presentes nos exoesqueletos são removidos na terceira etapa do tratamento através do etanol ou acetona, ou ainda por processo de branqueamento através de $\mathrm{KMNO}_{4}, \mathrm{NaOCl}, \mathrm{SO}_{2}$, $\mathrm{NaHSO}_{3}, \mathrm{Na}_{2} \mathrm{~S}_{2} \mathrm{O}_{4}$ ou $\mathrm{H}_{2} \mathrm{O}_{2}$ (MUZZARELLI, R.A.A., 1985).

A reação de desacetilação da quitina pode chegar atingir de 70 a 90\%, sendo que ao atingir $30 \%$ a quitina passa a ser denominada de quitosana. $\mathrm{Na}$ reação de desacetilação os grupamentos acetamido $\left(\mathrm{NHCOCH}_{3}\right)$ da quitina são transformados em grupos amino $\left(\mathrm{NH}_{2}\right)$, como esquematizado na figura 3 (KIMURA, I.Y., 2001). 


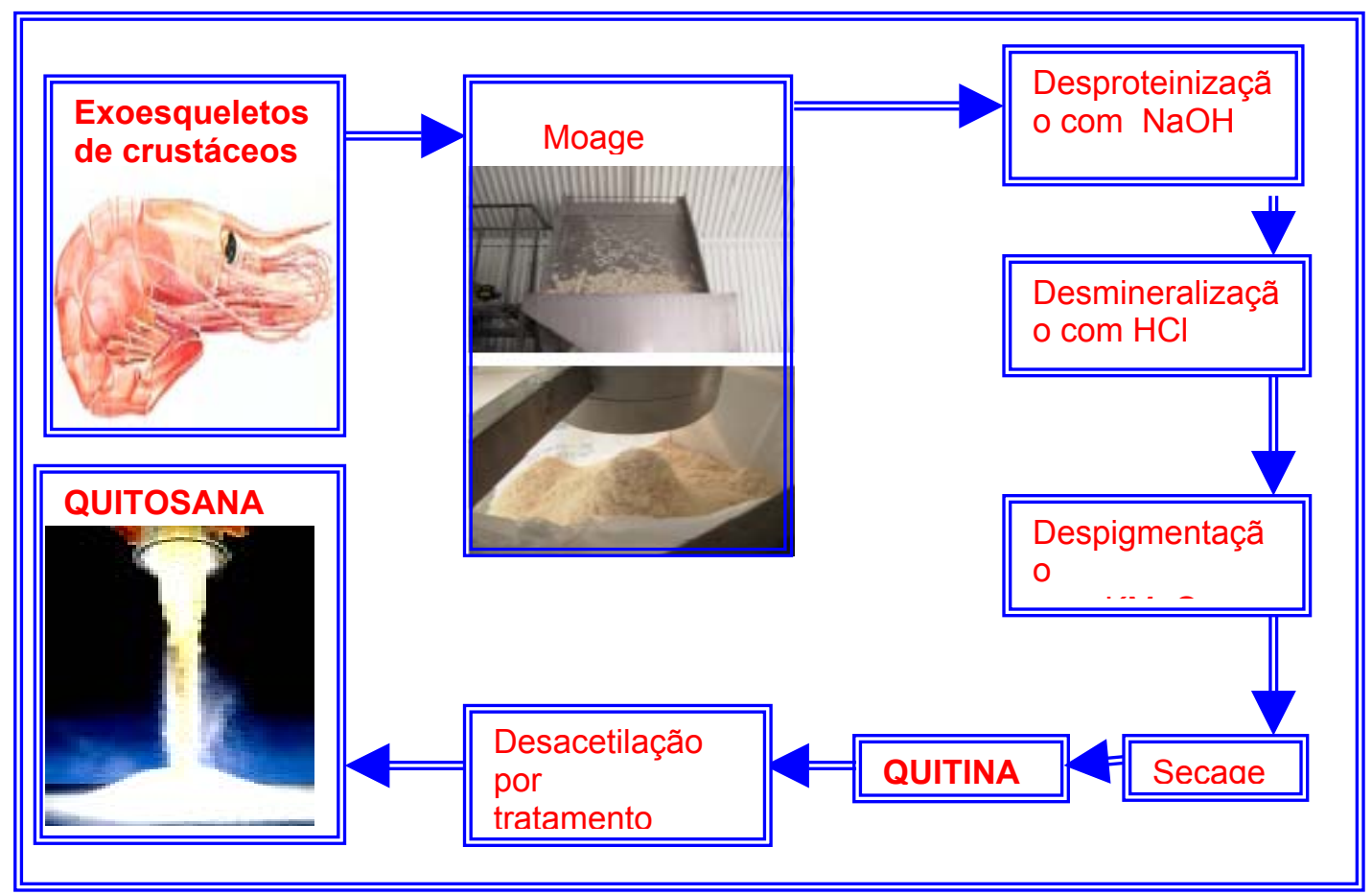

Figura 6 - Esquema do processo de obtenção de quitina e quitosana.

\subsection{QUITOSANA}

A quitosana é a forma desacetilada da quitina. São polímeros formados por longas cadeias de monossacarídeos unidos por ligações glicosídicas. Em uma definição mais atualizada são copolímeros lineares 2acetoamino-2-deoxi-glicopiranose (quitina) e 2-amino-2-deoxi-glicopiranose (quitosana).

Os termos quitina e quitosana são amplamente utilizados, mas nenhum deles representa uma estrutura química única, são melhores definidos como copolímeros de unidades de N-acetil-D-glicosamina e D-glicosamina, respectivamente.

Em pH ácido a quitosana comporta-se como um polieletrólito, com alta densidade de carga, sendo uma carga positiva para cada unidade de glicosamina. Considerando-se que materiais como proteínas, polissacarídeos aniônicos, ácidos nucléicos, ácidos graxos entre outros, apresentam cargas negativas vem justificar a excelente atividade da quitosana sobre eles (WANG, G., et al., 1992 \& DOMARD. A., 1987). 
A quitosana quando solubilizada em meio ácido, forma soluções viscosas, sua solubilidade está relacionada com a quantidade de grupos protonados $\left(\mathrm{NH}_{3}{ }^{+}\right)$presentes, responsáveis pela repulsão eletrostática entre as cadeias e solvatação em água. $\mathrm{O}$ pka dos grupos $\left(\mathrm{NH}_{3}{ }^{+}\right)$é de aproximadamente 6,5, assim aumentando o $\mathrm{pH}$ das soluções de quitosana acima deste valor ela sofre precipitação na forma de flocos gelatinosos (CHEN,R.H., 1996).

As duas características que melhor diferenciam os dois copolímeros são: o grau de desacetilação (GD) e a massa molar. O Grau de desacetilação acima de $30 \%$ caracteriza a quitosana. Como mencionado acima, a quitosana comercial geralmente apresenta grau de desacetilação variando entre $70 \%$ e $90 \%$ e a massa molar na faixa de $10^{4}-10^{6} \mathrm{~g} \mathrm{~mol}^{-1}$. (DOMARD, A. \& RINAUDO, M. et al., 1983).

A polidispersão ou distribuição da massa molar é influenciada pelas características utilizadas na reação de $\mathrm{N}$-acetilação como, tempo, temperatura, concentração e condições atmosféricas, devido a isto podemos obter amostras de quitosana com diferentes graus de desacetilação, viscosidade e distribuição da massa molar (CHEN, R.H. \& HWA, H.D., 1996).

As análises realizadas para caracterizar a quitina e a quitosana são: morfologia, cristalinidade, grau de umidade, grau médio de acetilação, determinação da massa molar e infravermelho (ROBERTS, G.A.F.R., 1992).

As principais características da quitosana que fazem dela um polissacarídeo de grande interesse para um número expressivo de aplicações são: poder ser quimicamente modificada; ser biodegradável e biocompatível; ser processada em diferentes formas (soluções, blendas, esponjas, filmes, membranas, gel, pasta, tabletes, microesferas, microgrânulos e fibras, entre outros), além de ser um polieletrólito catiônico em meio ácido.

Propriedades apresentadas pela quitosana para aplicação como biomaterial:

- biocompatibilidade e atoxicidade;

- biodegradabilidade (hidrólise enzimática por quitosanase e lisozima);

- bioadesividade;

- ação bacteriostática e antimicrobiana;

- capacidade de acelerar a formação de osteoblastos para formação de osso; 
- ação homeostática;

- ação imunoadjuvante;

- acelera o processo cicatricial de feridas;

- forma complexos com polieletrólitos aniônicos, como proteínas, polímeros, e outros;

- capaz de sofrer modificações químicas formando derivados com grande variação de propriedades e aplicações, podendo ser explorada em formas diversas, como descrito na tabela 2 (MUZZARELLI, R.A.A. 1973; KNORR, D.,1984; KENDRA, D.F.\& HADWIGER,L.A.,1989; SUDARSHAN, N.R. et al., 1992).

\section{Tabela 2 - Diferentes Aplicações da Quitosana nas Áreas: industrial e saúde/ nutricional}

\begin{tabular}{|l|l|}
\hline \multicolumn{1}{|c|}{ INDUSTRIAL } & \multicolumn{1}{c|}{ SAÚDE / NUTRICIONAL } \\
\hline - Purificação de água residual de & - Agente absorvedor de gordura \\
indústrias & - Redução de colesterol LDL \\
- Estabilizantes de gorduras em & - Regeneração de ferimentos \\
preparações de alimentos & - Antiácido \\
- Estabilizantes de aromas & - Auxiliar no controle da pressão arterial \\
- Meio de troca iônica & - Regenerador de estrutura óssea \\
- Aditivos de cosméticos e xampus & - Redução do nível de ácido úrico \\
- Absorventes na remoção de metais & - Promoção da perda de peso \\
pesados & - Bactericida/ antiviral \\
- Proteção bactericida de sementes & - Inibe a formação de placas dentárias \\
- Estabilizante de frutas e verduras & bacterianas \\
perecíveis & - Aumenta a absorção de cálcio \\
- Agente imobilizante de & - Membranas artificiais \\
Microrganismos & \\
\hline
\end{tabular}

Fonte: CRAVIEIRO, A.A.et al, 2004

Para a utilização da quitosana como um biomaterial é indispensável a realização de testes de toxicidade no organismo. Os testes biológicos realizados têm demonstrado segurança, inclusive quanto à mutagenicidade, toxicidade subcutânea e cutânea, toxicidade crônica, pirogênese, hemólise e 
sensibilização, isso faz com que a quitosana seja um excelente candidato a biomaterial. (SHAHIDI, F. et al., 1999; RABEA, E.I. et al., 2003; POLYMAR, 2004; PADETEC, 2004).

\subsubsection{EFEITO ANTIMICROBIANO DA QUITOSANA}

O uso indiscriminado de antimicrobianos associados ao fenômeno de resistência apresentado pelos microrganismos têm levado pesquisadores a intensificar a investigação de novas substâncias naturais que possam exercer efeitos satisfatórios na antibioticoterapia. A quitosana e seus derivados têm sido amplamente pesquisados como agentes antimicrobianos, e nos últimos anos têm recebido uma atenção especial, graças aos resultados apresentados na inibição do crescimento de bactérias, fungos e leveduras. A quitosana e oligômeros de quitosana apresentam propriedades biológicas, como biocompatibilidade (HIRANO, S. et al., 1988; MUZZARELLI, R.A.A.1988), biodegradação (SASHIMA, H. et al., 1993), bioreabsorção (NORDTVEIT et al., 1994), bioatividade (MUZZARELLI, R.A.A.1996).

A quitosana é solúvel em soluções de ácidos orgânicos em pH menores que 6,0 (MUZZARELLI, R.A.A., 1973).

O mecanismo de ação da quitosana sobre os microrganismos ainda não está bem definido, mas várias propostas são sugeridas pelos pesquisadores, dentre elas, temos:

- Ligação da quitosana à membrana da célula do microrganismo carregada negativamente, resultando na perda de componentes intracelulares.

- Uma outra possibilidade é dada em função da ação quelante da quitosana, que se liga seletivamente a traços de elementos ou nutrientes essenciais, bem como inibir o crescimento bacteriano (YOUNG, D.H.; KOHLE. H. \& KAUSS, H. 1982; HELANDER, I.M. et al.2001).

Associado a isso, tem a ação da quitosana na ativação de diversos mecanismos de defesa nos hospedeiros, pois age seqüestrando água e inibe várias enzimas (RAMADAN, A. M. 1997).

O efeito antimicrobiano das soluções de quitosana testadas sobre os microrganismos tem sido influenciado pelas características físicas das 
soluções, como o grau de desacetilação, peso molecular, concentração utilizada, tempo de exposição, viscosidade e $\mathrm{pH}$. Além das características das soluções de quitosana, deve ser considerado o tipo de microrganismo, pois os estudos realizados demonstram que a ação inibitória da quitosana e seus derivados apresentam maior eficácia contra bactérias Gram positivas do que Gram negativas.

CHANG, D.S. et al., 1989 demonstraram que para causar eliminação total de Staphylococcus aureus em 48 horas foram utilizadas soluções de quitosana de concentrações iguais a $0,005 \%$ ou maiores, enquanto que WANG, G. 1992, precisou utilizar soluções de quitosana em concentrações maiores que 1,0 e 1,5\%, num tempo de incubação de 24 horas para obter o mesmo resultado.

WANG, G. 1982 para demonstrar a inativação completa de Escherichia coli, utilizou concentrações de 0,5 e 1,0\% de quitosana, após 48 horas de incubação, e este resultado pode ser obtido em 24 horas se a concentração da quitosana for maior que $1,0 \%$.

NO, H. K. et al., 2002 investigaram seis tipos de quitosana e seis tipos de oligômeros de quitosana de diferentes pesos moleculares para quatro tipos diferentes de bactérias Gram negativas e sete tipos diferentes de bactérias Gram positivas. Os resultados demonstraram que a quitosana apresentou maior atividade antibacteriana que seus oligômeros, embora esse efeito inibitório tenha sido diferenciado segundo o peso molecular para cada tipo de bactéria, e que a quitosana a $0,1 \%$ demonstrou maior efeito bactericida contra bactérias Gram positivas e Gram negativas.

DARMADJI, P. \& IZUMIMOTO, M., 1994 demonstraram a necessidade de utilizar concentrações maiores que 0,1\% para inibir o crescimento de Escherichia coli e SIMPSON, et al., 1997 demonstraram que para obter o mesmo resultado foi aplicada uma concentração de $0,0075 \%$ de quitosana.

XIE, W. et al., 2002 pesquisaram a ação inibitória de derivados de quitosana com alta porcentagem de cadeias enxertadas, os quais demonstraram maior solubilidade em água. Os derivados foram testados para Staphylococcus aureus (Gram positiva) e Escherichia coli (Gram negativa), sendo que o efeito foi mais eficaz contra o Staphylococcus aureus. 
ZHENG, L.Y. \& ZHU, J.F. 2003 observaram que soluções de quitosana a $1 \%$ e peso molecular de até $5 \mathrm{kDa}$ causaram ação inibitória contra Escherichia coli, e esta concentração apresentou ação bactericida para Staphylococcus aureus. Para soluções de quitosana com pesos moleculares inferiores a $5 \mathrm{KDa}$ não houve eficácia em nenhuma das concentrações estudadas, porém com o aumento do peso molecular houve aumento do efeito inibitório até na menor concentração testada.

SUDARSHAN, N.R. et al., 1992 avaliaram a ação bactericida do glutamato de quitosana e do lactato de quitosana, sendo $2 \mathrm{gL}^{-1}$ a concentração dos sais. Utilizaram nove tipos bacterianos, dentre eles a Salmonella typhimurium (Gram negativa), Observaram que não há ação específica para os tipos bacterianos testados e que a ação bactericida foi similar para os grupos Gram positivos e Gram negativos.

JOSUÉ, A. et al. I 2000 verificaram in vivo a liberação de eosina a partir de microesferas de quitosana enxertada com poli (ácido acrílico) e observaram que o corante foi liberado em função do tempo a pH 6,8 e 9,8 que simulam as condições fisiológicas do trato gastrointestinal, e nenhuma eosina foi liberada a $\mathrm{pH} \mathrm{1,2.}$

JEON, Y.J. et al., 2001 avaliaram o efeito de três tipos de quitooligossacarídeos com diferentes pesos moleculares (alto, médio e baixo) para vários microrganismos, patógenos e não patógenos. Os quitooligossacarídeos testados inibiram o crescimento das bactérias testadas, mas o melhor efeito inibitório foi do quitooligossacarídeos de alto peso molecular, acima de 10KDa.

TSAI, G.J. et al., 2002 investigaram a atividade antimicrobiana da quitina e quitosana quimicamente e microbiologicamente tratados para conservação de peixes. Usaram soluções de diferentes pesos moleculares e diferentes graus de desacetilação (pequeno, médio e alto) em pH 6,0 contra: bactérias Gram positivas (B. cereus, L. monocytogenes, e S. aureus), Gram negativas (E.coli, P.aeruginosa, S.dysenteriae, V.cholerae e $V$. parahaemolyticus) e fungos (C. albicans, F. oxysporum, A. fumigatus). A atividade antimicrobiana das soluções foi maior com o aumento do grau de desacetilação, sendo mais eficiente contra bactérias do que contra fungos. Obtiveram uma concentração letal mínima (CLM) de 50-200 ppm para: 
B.cereus, E. coli, L. monocytogenes, P. aeruginosa, Shigella dysenteriae, S.aureus, V. cholerae e V. parahaemolyticus; 200 ppm para C. albicans; 500 ppm para F.oxysporum; e nenhuma eficácia contra $A$. fumigatus.

TARSI, G.J. et al., 1998 relataram que os Streptococcus mutans apresentam menor adesividade à hidroxiapatita quando tratados por soluções de quitosana e de seus derivados com baixo peso molecular.

NO, H. K. et al., 2002 avaliaram a atividade antimicrobiana de seis soluções de quitosana e seis soluções de oligômeros de quitosana com diferentes pesos moleculares, através da técnica de difusão em ágar com discos de papel impregnados com as soluções para microrganismos isolados do Tofu. Observaram que as soluções de quitosana apresentaram maior efeito antimicrobiano que as de seus oligômeros.

SEKIGUCHI, S. et al., 1994 trabalharam com oligômeros de quitosana com pesos moleculares entre 2350 e 21600Da para vários tipos bacterianos e relataram que o Bacillus cereus teve seu crescimento suprimido em ágar com oligômeros de quitosana a 0,2-0,3\% e de peso molecular de 11000Da.

RIVAS, L.G. et al., 2004 avaliaram a ação antimicrobiana da quitosana em diferentes concentrações contra leveduras de putrefação em fermentação de cultura mista e observaram a inativação da maioria das leveduras, sendo que o Sacaaharomyces cerevisiae só sofre inibição em concentrações mais elevadas de quitosana.

UCHIDA, Y. et al., 1989 compararam o efeito antimicrobiano de quitosana hidrolisada pela enzima quitosanase com a quitosana nativa e oligômeros de quitosana e observaram que a forma hidrolisada se mostrou mais eficiente que as outras. CHO, H.R. et al., 1998 relataram que a ação antimicrobiana da quitosana para Escherichia coli e Bacillus sp é aumentada com a diminuição da viscosidade da solução.

CHOI, B.K. et al., 2001 utilizaram quitooligossacarídeos a 0,1\% para Actinobacillus actinomycetemcomitans e Streptococcus mutans. Observaram que a inativação do $A$. actinomycetemcomitans foi maior com o aumento do tempo de exposição, e que a ação inibitória para o $S$. mutans além de ser menor, não se alterou com o aumento do tempo de exposição. Os autores acreditam que os resultados obtidos estejam relacionados à baixa concentração utilizada. 


\subsection{Enteropatógenos}

As enterobacteriáceas são caracterizadas fenotipicamente como:

- bacilos ou bastonetes,

- Gram negativos,

- anaeróbias facultativas,

- não esporulantes,

- usualmente reduzem nitrato a nitrito e a $\mathrm{N}_{2}$,

- fermentam a glicose e outros açúcares originando uma variedade de produtos finais;

- são oxidase-negativas

- catalase-positivas,

- imóveis ou móveis por flagelação peritríquia. (MADIGAN, 2004).

Apresentam atividade metabólica bastante ampla, a qual é extensivamente utilizada no processo de classificação e identificação dos gêneros, espécies e biotipos da família. (TRABULSI, L.R. et al, 2004).

A classificação desta família tem passado por grandes mudanças, em conseqüência dos métodos moleculares empregados. Mesmo não tendo consenso total, se aceita atualmente que a família seja composta por trinta gêneros e mais de cem espécies. Estes gêneros têm sido divididos em dois grandes grupos, sendo que o primeiro é formado pelas enterobacteriáceas conhecidas antes de 1980, responsáveis por aproximadamente $90 \%$ das amostras mais freqüentes isoladas de infecções humanas. O segundo é subdividido em três subgrupos, estes incluem espécies raras de origem humana, espécies predominantemente ambientais e espécies ainda não isoladas no homem, de acordo com o Manual de Bergey's até 1980. Os aspectos estruturais das enterobacteriáceas estão representados na figura 7 , a qual demonstra membrana citoplasmática, espaço periplásmico, peptidoglicano ou mureína, membrana externa. A maioria é móvel, apresentando filamento flagelar e cápsula ou estrutura do tipo capsular conhecidas como antígenos $\mathrm{K}$ ou "Vi", no caso das salmonelas. A membrana externa é composta por LPS (lipopolissacárides), porinas, e diferentes tipos de fímbrias. 
O cromossomo é único e circular, além de poder apresentar vários plasmídios (fração circular de DNA, com informações genéticas de virulência e resistência às drogas) no citoplasma. (TRABULSI, L.R. et al., 2004).

As enterobacteriáceas podem ser móveis ou imóveis (atríquias), as móveis são peritríquias, apresentam flagelo em toda a periferia.

O flagelo é formado pela proteína flagelina, ou antígeno "H", de diâmetro bem reduzido, mas de comprimento superior ao da célula, tem função locomotora e está diretamente relacionado à quimiotaxia. (TRABULSI, L.R. et al., 2004).

\subsubsection{Estruturas da célula bacteriana Gram negativa}

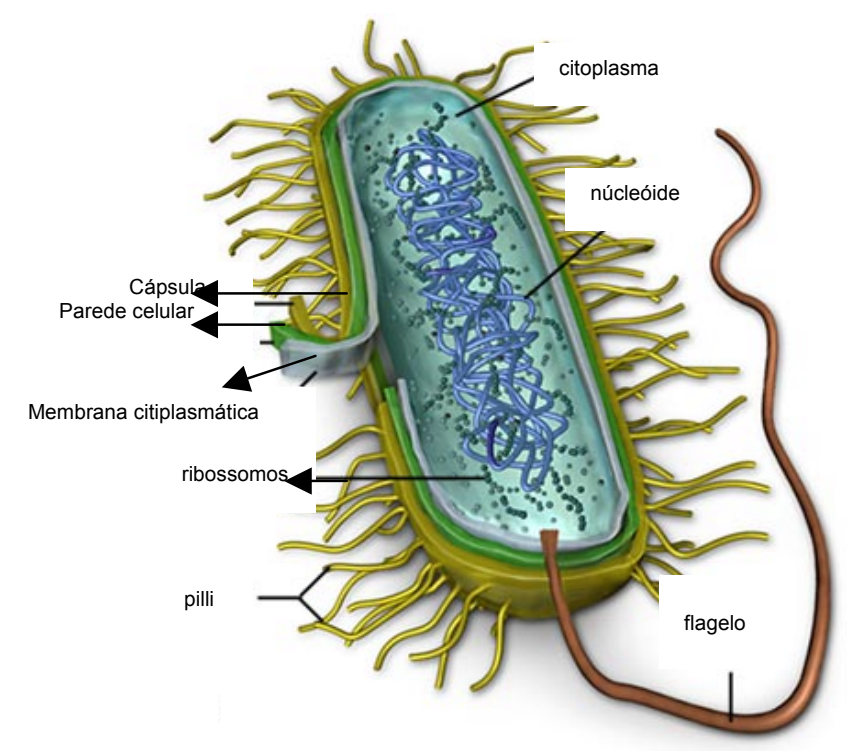

Figura 7. Representação esquemática de uma Enterobacteriácea. Fonte: http://micro.magnet.fsu.edu/cells/bacteriacell.html

O tempo de geração é bastante variável, segundo as características nutricionais e genéticas de cada bactéria. A E.coli, em excelentes condições desenvolve o ciclo em 20 minutos, como a maioria das enterobacteriáceas, mas temos agentes como Mycobacteruim tuberculosis que desenvolve a geração em 24horas (MADIGAN, M.T. et al., 2004).

A Escherichia coli, é uma bactéria geneticamente bem conhecida, pois já teve seu DNA todo seqüenciado, o qual apresenta por volta de 4,6 milhões de pares de bases, contendo cerca de 4300 genes, equivalente a $10 \%$ do 
volume celular. Em algumas bactérias a quantidade de genes chega a ser três vezes maior que da E.coli, porém as células eucarióticas (diplóides), no geral contém mais genes, aonde o DNA chega a atingir um tamanho de 1000 vezes maior que o da $E$. coli e o número de genes chega a sete vezes maior que a mesma (TRABULSI et al, 2004 \& MADIGAN, 2004)

A detecção dos enteropatógenos bacterianos é complicada em função da abundante e complexa microbiota normal presente, representado pelo fluxograma na figura 8 , além de outros mecanismos de defesa do hospedeiro que agem em conjunto.

A ingestão diária de grande inóculo de microrganismos raramente sobrevive em número suficiente para chegar ao intestino e causar infecção, graças aos mecanismos de defesa do hospedeiro.

\subsubsection{Ação dos enteropatógenos nas infecções intestinais.}

$\mathrm{Na}$ boca temos o fluxo líquido da saliva com lisozima e microbiota normal. No estômago temos a excelente barreira ácida capaz de eliminar boa parte dos patógenos. O intestino dispõe de vários recursos, como fluxo dos conteúdos gástricos, peristaltismo, muco, bile, Ig A secretora, tecido linfóide, liberação e substituição do epitélio e uma complexa microbiota.

A dieta interfere diretamente na microbiota, pois o consumo de carne vermelha leva a uma quantidade maior de anaeróbios nas fezes em relação ao consumo de peixes e de vegetais. A microbiota de lactentes difere da de adultos devido à alimentação rica em lactose o que favorece os Lactobacillus, responsáveis pela produção de fezes ácidas (MURRAY, P.R. et al. 2003).

É de extrema importância lembrar aqui o valor do aleitamento materno, pois o leite materno humano é enriquecido com Lactobacillus bifidus, além de conter de 1 a $6 \mathrm{mg} / \mathrm{ml}$ de lactoferrina, pequenas quantidades de tranferrina $\mathrm{e}$ lisozima cerca de 3.000 vezes superior à encontrada no leite de vaca. Estes componentes exercem ação bacteriostática sobre E.coli e Cândida albicans. (WILCOX, C.M.et al., 1996).

A lisozima associada à Ig A lisa a E.coli e na presença de peroxidase e ascorbato, também presentes no leite humano, atuam contra Streptococcus sp, 
Pseudomonas sp e Salmonella sp (SIMON, G.L. e GORBACH, S.L. 1991). Além destes componentes já foi comprovado a presença de 0,5 a 10 milhões/ml de leucócitos e outras células viáveis, são macrófagos, leucócitos PMN, e linfócitos T e B, conferindo proteção contra agentes como C. tetani, $C$. diphtheriae, S. pneumoniae, E.coli, Salmonella e Shigella. Podemos afirmar a partir das características acima citadas que o leite materno humano é mais um dos mecanismos de defesa do lactente contra os agentes agressores do ambiente (GOLDMAN, A.S. 1977).

\section{COMPOSIÇÃO DA MICROBIOTA DO APARELHO DIGESTIVO HUMANO}

- saliva: microbiota mista de cerca de $10^{8}$ germes $/ \mathrm{mL}$

- cavidade oral:

- cocos Gram positivos: - Streptococcus alfa e gama - hemolítico,

- S.epidermidis e S.aureus

-cocos Gram negativos: - Branhamella catarrhalis, Neisseria sp.

- bacilos Gram positivos: - Corynebacterium sp (difteróides)

- espirilos: - Treponema (bucalis, denticum, intermedium)

- Anaeróbios: - Bacteroides sp, Fusobacterium sp, Peptostreptococcus sp, Actinomyces sp

- fungos: Cândida sp

- bacilos Gram negativos: raramente observados, são decorrentes da dieta, geralmente transitórios.

- esôfago, estômago e intestino delgado:

Praticamente não apresentam microbiota residente, em função do ácido clorídrico, gástrico e enzimas pépticas.

- intestino grosso de adultos: $10^{10}$ bactérias/ grama de fezes, $25 \%$ do peso

- 90\% anaeróbios: das fezes. A microbiota mais variada do corpo.

- bacilos Gram positivos: Bacteróides sp.

- bacilos Gram positivos: Eubacterium sp, Clostridium sp, Lactobacillus sp, Fusobacterium sp.

- cocos Gram positivos: Peptostreptococcus sp.

$-10 \%$ aeróbios:

- bacilos Gram negativos: - 90\% - E.coli e - 10\%, Enterobacter, Proteus, Morganella e Pseudomonas

- cocos Gram positivos: Streptococcus faecalis e outros enterococos.

- fungos: Cândida sp.

- Lactentes: - 90\% anaeróbios:

- bacilo Gram negativo: Bifidobacterium sp,

- bacilo Gram positivo: Lactobacillus sp. - 10\% aeróbios: - cocos Gram positivos: Streptococcus sp.

Figura 8 - Composição da Microbiota do aparelho digestivo do homem.

Fonte: PELCZAR, JR, et al., 1997. 
Crianças amamentadas com leite de vaca desenvolvem flora microbiota comensal idêntica a de adultos. (GOLDMAN, A.S.1977)

Para que haja infecção intestinal algumas etapas são essenciais, como a dose infectante do patógeno, o qual deverá apresentar condições de virulência que o torne capaz de vencer os mecanismos de defesa do hospedeiro para então chegar ao intestino, onde se fixará para só depois colonizá-lo e finalmente exercer seu mecanismo toxígeno e ou invasor.

\subsubsection{Mecanismos de patogenicidade dos enteropatógenos}

São dois os mecanismos básicos pelos quais os enteropatógenos provocam danos intestinais, ação toxígena que desencadeia a diarréia e a ação invasora que desencadeia a disenteria (BYTZER, P. et al., 1990).

No quadro diarréico temos as a ação das enterotoxinas LT e ST. A toxina LT, termolábil (heat labile), peso molecular aproximadamente de 100.000 daltons, é imunogênica. Ela se fixa aos receptores gangliosídicos da mucosa intestinal, adentra os enterócitos estimula a produção de AMP cíclico perturbando o equilíbrio hidrossalino da mucosa, elevando a secreção de $\mathrm{Na} \mathrm{Cl}$ e bicarbonato ao nível da cripta e bloqueando a absorção de $\mathrm{Na} \mathrm{Cl}$ ao nível de vilosidade. A toxina ST (heat stable), de peso molecular de 5.000 daltons, não é imunogênica e altera o metabolismo hidrossalino por estimular a formação de GMP cíclico, o qual promove a secreção de $\mathrm{Cl}$ e a diminuição da absorção de $\mathrm{Na} \mathrm{Cl}$ no nível das microvilosidades. A grande quantidade de fluidos acumulados em ambos os mecanismos excede a capacidade de absorção do intestino grosso, causando a diarréia. Os fluidos perdidos durante a diarréia além de água há grande quantidade de sódio, potássio e bicarbonato, causando desidratação, hipovolemia e acidose, em casos mais graves o choque que pode tornar o quadro fatal (LADEFOGED, K, 1987).

No quadro disentérico a bactéria penetra na célula epitelial, prolifera em seu interior e a destrói. O processo determina reação inflamatória na lâmina própria do intestino grosso. Neste caso os fluidos perdidos geralmente não são em grande quantidade, os sintomas incluem febre e dores abdominais (TRABULSI, L.R. et al 2004). 


\subsubsection{Escherichia coli}

E.coli é a bactéria mais conhecida pelo homem. Capaz de apresentar uma diversidade patogênica expressiva, pelo menos cinco categorias causam infecções intestinais (diarreiogênicas), através de diferentes mecanismos, além das infecções extraintestinais (EXPEC, Extraintestinal Pathogenic E.coli). A E.coli também é componente da microbiota do intestino do homem e de animais, sendo usada como referência de contaminação fecal quantitativa de água e alimento, fundamental importância à Saúde Pública.

As E.coli diarreiogênicas, são caracterizadas pelas diferentes propriedades de virulência, diferentes processos de interação com a mucosa do intestino, quadros clínicos e epidemiológicos distintos. São elas: E.coli Enteropatogênica clássica (EPEC), E.coli Enterotoxigênica (ETEC), E.coli Enteroinvasora (EIEC), Escherichia coli Enterohemorrágica (EHEC), E.coli Enteroagregativa (EAEC), E.coli Aderência Difusa (DAEC) (TRABULSI, L.R. et al., 2004).

E.coli EPEC, enteropatogênica, foi descrita em 1920 e 1930 como sendo a primeira E.coli diarreiogênica. (TRABULSI, L.R. et al., 2004). Desde então tem passado por várias modificações quanto a sua definição. (KAPER, J.B. 1996).

Hoje, podemos contar com o seqüenciamento completo do sorotipo 0127: H6, o que torna a EPEC uma das bactérias mais estudadas e conhecidas pelo homem. (TRABULSI, L.R.et al., 2004).

Durante o $2^{\circ}$ Simpósio Internacional sobre EPEC, ocorrido em São Paulo em 1995, pesquisadores a classificaram em duas categorias, EPEC típicas e EPEC atípicas. (KAPER, 1996) As EPEC típicas apresentam o plasmídio EAF (EPEC adherence factor), não produtoras da toxina Shiga (Stx), produtoras de um tipo de lesão característica denominada attaching- andeffacing $(A / E)$. As EPEC atípicas se diferem das anteriores por não apresentarem o plasmídio EAF (EPEC adherence factor) (TRABULSI, L.R. et al., 2004).

As EPEC causam diarréia líquida com muco, febre e desidratação. Acometem mais freqüentemente crianças muito jovens, no período de 
desmame, sendo incomum em crianças em amamentação exclusiva pelo peito. Em estudos com adultos voluntários apresenta período de incubação de 9 a 10 horas. Em crianças a diarréia pode ser severa e prolongada, atingindo uma taxa de letalidade de $50 \%$ nos países em desenvolvimento. A dose infectiva da EPEC em crianças é presumivelmente baixa. [BEBEBSON, A.S. (Ed.). 1995]

$\mathrm{Na}$ ação patogênica as EPEC atravessam a barreira gástrica e se aderem à mucosa do intestino delgado e grosso. O processo de adesão ocorre em duas etapas, à primeira delas, conferida pela ação das fímbrias BFP codificadas pelos genes do plasmídio EAF formando microcolônias localizadas na superfície das células do epitélio intestinal.

Posteriormente à formação das microcolônias inicia-se a segunda etapa através da ação das intiminas, que são adesinas (proteínas) responsáveis pela aderência íntima da bactéria no epitélio intestinal (TRABULSI, L.R. et al., 2004).

A figura 9 apresenta as alterações desenvolvidas pela EPEC na mucosa intestinal inicialmente há formação de pedestais, aos quais as EPEC se fixam como se estivessem deitadas sobre eles e posteriormente há a destruição das microvilosidades intestinais. Este tipo de lesão é denominado A/E (attaching-and-effacing). Outros fatores envolvidos no processo são: alterações da secreção de íons, abertura das junções epiteliais e processo inflamatório desenvolvido (CELLI, J. et al., 2000).

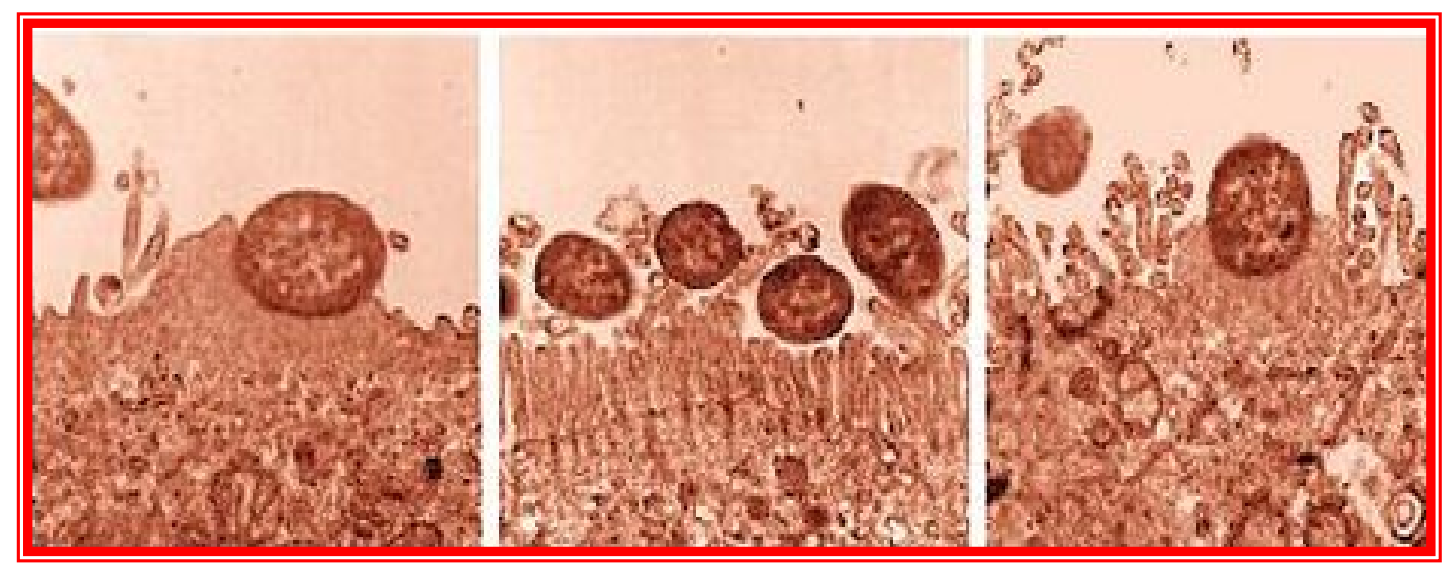

Figura 9 - Microscopia de transmissão, amostra de EPEC com adesão em forma de pedestais e conseqüente destruição das microvilosidades intestinais ( lesão A/E). (464 x 157 pixels - 27.1kB).

Fonte: http://www.medschool.umaryland.edu/cvd/kaperlab/Figures.html 
Além do homem, bovinos e suínos podem ser portadores dessa bactéria na microbiota intestinal.

O tratamento é feito principalmente pela hidratação oral ou endovenosa para reposição de líquido e eletrólitos, mas nos casos severos é administrado Trimetropim/Sulfametoxazol (TMP-SMX) 10-50 mg/kg/dia, de três a quatro doses, durante cinco dias [BEBEBSON, A.S. (Ed.). 1995].

\subsubsection{Shigella sonnei}

O gênero Shigella é composto por quatros sorogrupos, os quais são designados como espécies, são eles: S. dysenteriae ou sorogrupo A contendo 14 sorotipos, S. flexneri ou sorogrupo B contendo 6 sorotipos, S. boydii ou sorogrupo C contendo 18 sorotipos e S. sonnei ou sorogrupo D contendo um único sorotipo. Os sorogrupos A, B e C são bastante similares fisiologicamente, enquanto que a $S$. sonnei se difere quanto à descarboxilação da ornitina e produção de $\beta$ - D- galactosidase. Os sorotipos são desprovidos de antígeno capsular e flagelar, sendo identificados apenas pelo antígeno O (TRABULSI, L.R. et al., 2004).

A primeira amostra do gênero foi descrita em 1898 por Shiga no Japão, como sendo agente de uma epidemia de disenteria bacilar severa (MURRAY, P.R. et al., 2003).

As quatro espécies são causadoras de doença bacteriana aguda que envolve o intestino delgado, é conhecida como disenteria bacilar. Tem como características dor abdominal e cólica, diarréia com sangue, pus e muco; febre, vômitos e tenesmo, podendo em alguns casos apresentar diarréia líquida. As infecções graves estão associadas a uma ulceração da mucosa com sangramento retal e desidratação acentuada. Algumas cepas podem causar complicações como bacteremias, convulsões, artrite crônica de Reiter (associada à S. flexneri), SHU (associada à S. dysenteriae tipo1) [BEBEBSON, A.S. (Ed.). 1995].

As shigeloses podem ser causadas por um inóculo extremamente reduzido, através da ingestão de 10 - 100 bactérias. O período de incubação é de 12- 48 horas após a ingestão do agente. A duração média dos sintomas é 
de quatro a sete dias, mas o agente pode ser cultivado através das fezes por 30 dias ou mais. (SILVA, L.H.P. M, 1999).

As manifestações clínicas são conseqüências da ação das enterotoxinas conferidas pos genes cromossomais e ação invasora conferida por genes plasmidiais. As infecções podem ser assintomáticas $(50 \%$ dos casos), episódios benignos de diarréia aquosa, até formas severas de disenteria bacilar clássica. Os fatores determinantes para as manifestações são a dose infectante (número de bactérias ingeridas) e as condições do paciente.

A disenteria bacilar clássica é uma doença toxigênica causada pela Shigella dysenteriae, caracterizada por diarréia aquosa volumosa, febre, cólicas abdominais e tenesmo, com emissão de fezes mucopurulentas e sanguinolentas. O paciente pode também apresentar anorexia, náuseas, vômitos, calafrios, estado toxêmico, convulsões e sinais miningíticos. O modelo de invasão de células intestinais está representado na figura 10 (TRABULSI, L.R. et al., 2004).

A diarréia leve ou moderada é caracterizada pela diarréia aquosa, podendo durar alguns dias sem eliminação de fezes disentéricas (TRABULSI, L.R. et al., 2004).

Segundo a OMS, nos últimos anos tem havido conscientização da repercussão mundial da Shigella como patógeno intestinal, das conseqüências devastadoras quanto ao ritmo de aquisição de resistência às drogas e a necessidade de investir no desenvolvimento de vacinas.

A distribuição é mundial, estimando que a shiguelose seja responsável por cerca de 600.000 mortes no mundo; cerca de dois terços dos casos e a maioria de mortes na faixa de menos de dez anos de idade. É endêmica em países em desenvolvimento e de clima tropical, principalmente as espécies S.sonnei e S. dysenteriae. No estado de São Paulo, os casos notificados ao CVE dos surtos das doenças transmitidas por alimentos e águas são de 2 a 5\% causados por Shigella, envolvendo em média 300 pessoas por ano [BEBEBSON, A.S. (Ed.). 1995].

O estudo realizado sobre a carga mundial de infecção por Shigella revelou que os sorogrupos $S$. sonnei e $S$. flexneri são os mais freqüentemente isolados, seja em países em desenvolvimento ou industrializados. Os países 


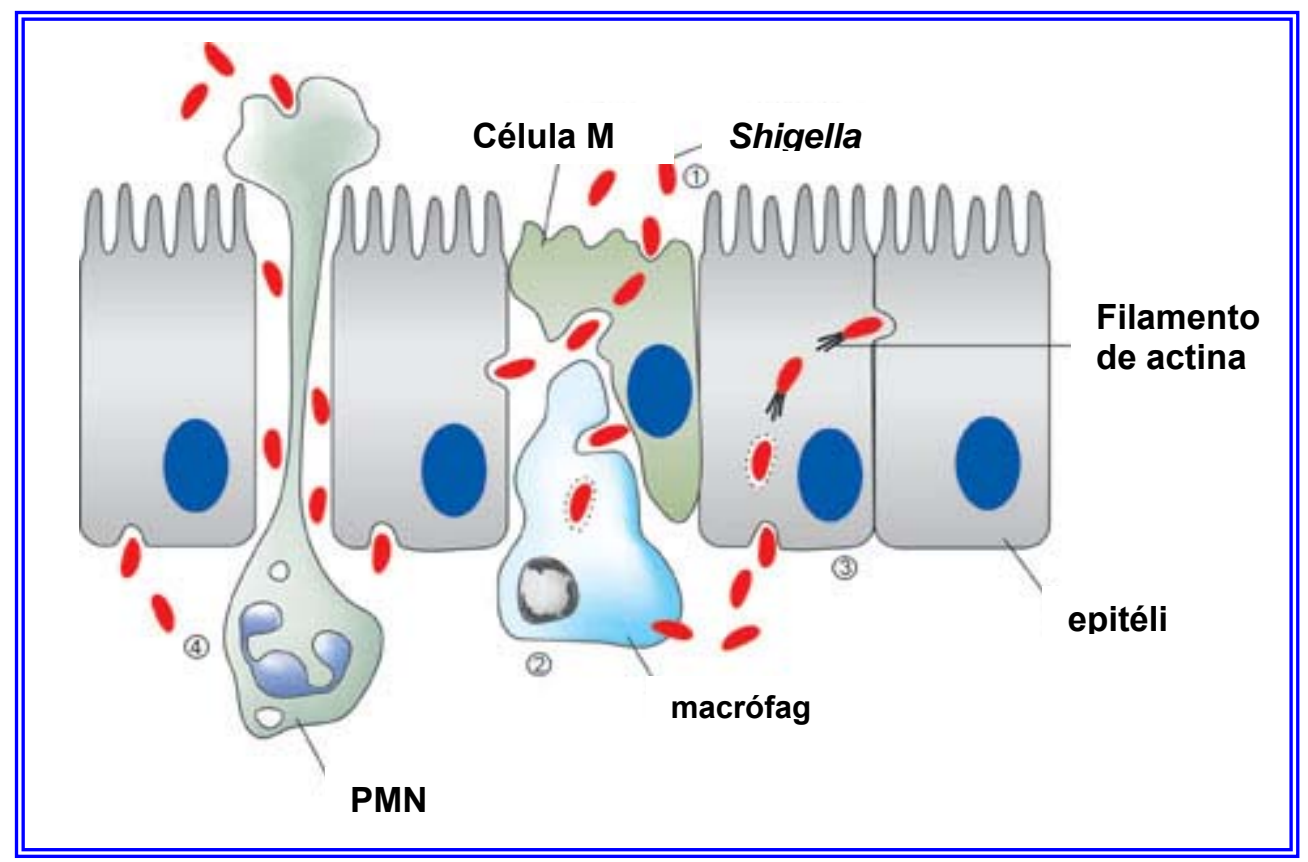

Figura 10 : Mecanismo de patogenicidade de Shigella sp.

Fonte: www.mpg.de/./ abbildung1.jpg 456 x 317 pixels - 27kl nfektion

industrializados apresentaram índices de $77 \%$ e $16 \%$ destes sorogrupos, respectivamente, enquanto que os países em desenvolvimento apresentaram índices de $15 \%$ e $60 \%$ dos respectivos sorogrupos (KOTTOFF, K. L. et al., 2000).

Em adultos os índices de prevalência são semelhantes aos de crianças com mais de dois anos de idade (TRABULSI, L.R. et al., 2004). No geral, é mais grave em crianças e em idosos debilitados e desnutridos e em pacientes com AIDS. O aleitamento materno protege as crianças [BEBEBSON, A.S. (Ed.). 1995].

O tratamento é normalmente realizado por hidratação oral ou venosa, mas dependendo da gravidade da doença podem ser utilizados antibióticos.

\subsubsection{Salmonella}

Os primeiros relatos sobre as salmonelas datam de 1856, cerca de vinte anos antes da moderna era bacteriológica. Willian Budd descreveu o agente da febre tifóide. Em 1880, Eberth, observou o bacilo tífico através de exame histopatológico de órgãos de doentes vitimados pela febre tifóide. Em 
1884, Gaffky, também discípulo de Robert Koch, isolou o agente em cultura pura. (BIER, O., 1990)

As Salmonelas infectam o homem e praticamente todos os animais domésticos e selvagens, incluindo pássaros, répteis e insetos. No homem elas causam vários tipos de infecção, sendo a gastroenterite e a febre tifóide as mais comuns (VERONESI, R. \& FOCACCIA, R., 1997).

A classificação e a nomenclatura sofreram várias modificações, sendo que a mais atual é baseada em estudos moleculares dividindo o gênero em duas subespécies: Salmonella enterica e Salmonella bongori. A S. enterica é subdividida em seis subespécies, designadas por números romanos representados na tabela 3. São elas: subespécie I com 1478 sorotipos; subespécie II com 498 sorotipos; subespécie IV com 71 sorotipos; IIlb com 327 sorotipos; subespécie VI com 12 sorotipos e a subespécie Illa com 94 sorotipos, portanto 2408 no total. Quanto à espécie S. bongori, esta apresenta 21 sorotipos diferentes (TRABULSI, L.R. et al. 2004).

Os sorotipos da subespécie I são designados por um nome geralmente relacionado ao local onde o agente foi isolado pela primeira vez. Este nome não é mais escrito em itálico e sua primeira letra é maiúscula, como: Salmonella Enteritidis, Salmonella Dublin, Salmonella Newport. Os sorotipos das demais subespécies, assim como da espécie $S$. bongori são designados apenas por seus determinantes antigênicos $\mathrm{O}$ (somáticos), $\mathrm{H}$ (flagelares) e $\mathrm{Vi}$ (capsulares) (KAUFFMANN, F. 1978). Anteriormente, cada sorotipo ou sorovariedade de Salmonella era considerada uma espécie distinta. (POPOFF, M.Y. et al., 1995). Na subespécie I está incluída a maioria das Salmonelas patógenas para o homem (BOYD, E.F. et al., 1996).

Dependendo da sorovariedade ou sorotipo bacteriano e do tipo de hospedeiro envolvidos, as $S$ enterica patogênicas podem causar nos mamíferos desde gastrenterites localizadas à mucosa intestinal até infecções sistêmicas graves (SALYERS, A.A. \& WHITT, D.D. 1994). A S. enterica Typhi é o agente da febre tifóide, causando infecção sistêmica grave no homem.

No Brasil, a partir de 1993 foi detectado um aumento expressivo de S. enterica Enteritidis e desde 1994, este tem sido o sorotipo isolado com mais freqüência de infecções humanas, de materiais de origem não humana e 
principalmente de alimentos consumidos pelo homem. (POPOFF, M.Y. et al, 1995).

\section{Tabela 3 - ESQUEMA ABREVIADO DE KAUFFMAN \& WHITE}

\begin{tabular}{|c|c|c|c|c|}
\hline Sorovar & Grupo & $\begin{array}{l}\text { Fórmula antigênic } \\
\text { Antígeno } O \\
\text { Fase } 1\end{array}$ & & \\
\hline S. Paratyphi A & $0: 2(A)$ & $1,2,12$ & $a$ & {$[1,5]^{*}$} \\
\hline S. Paratyphi B & $0: 4(\mathrm{~B})$ & $1,4[5], 12$ & $\mathrm{~b}$ & 1,2 \\
\hline S. Typhimurium & & $1,4[5], 12$ & $\bar{i}$ & 1,2 \\
\hline S. Agona & & $1,4,12$ & $f, g, s$ & {$[1,2]$} \\
\hline S.Derby & & $1,4[5], 12$ & $f, g$ & {$[1,2]$} \\
\hline S.Saintpaul & & $1,4[5], 12$ & $e, h$ & 1,2 \\
\hline S. Choleraesuis & $\mathrm{O}:\left(\mathrm{C}_{1}\right)$ & 6,7 & c & 1,5 \\
\hline S.Oranienburg & & $6,7,14$ & $\mathrm{~m}, \mathrm{t}$ & {$\left[Z_{57}\right]$} \\
\hline S Infantis & & $6,4,14$ & $r$ & 1,5 \\
\hline S.Newport & $0: 8\left(C_{2}-C_{3}\right)$ & $6,8,20$ & $e, h$ & 1,2 \\
\hline S. Typhi & $\mathrm{O}: 9\left(\mathrm{D}_{1}\right)$ & $9,12[\mathrm{VI}]$ & $d$ & - \\
\hline S. Enteritidis & & $1,9,12$ & $\mathrm{~g}, \mathrm{~m}$ & - \\
\hline S.Anatum & $\mathrm{O}: 3,10\left(\mathrm{E}_{1}\right)$ & $3,10[15] 15,34]$ & $e, h$ & 1,6 \\
\hline
\end{tabular}

Fonte: Murray, 2000.

A salmonelose é uma doença causada pelas salmonelas, onde se enquadra a toxinfecção alimentar. O período de incubação de 12 a 36 horas após a ingestão do alimento ou água contaminado, normalmente os pacientes apresentam náusea, vômito, diarréia dores abdominais, e a mialgia assim como dores de cabeça também são comuns. Febre (de $38-39^{\circ} \mathrm{C}$ ) e calafrios, $2 / 3$ dos pacientes queixam-se de "cãibras" abdominais. A febre e a diarréia duram de dois a sete dias. As infecções são mais graves em crianças e em adultos com mais de 60 anos. (VERONESI, R. \& FOCACCIA, R.1997).

Salmonella enterica, uma vez no intestino passa a se aderir e a invadir as células $M$ da mucosa intestinal, tipo de célula encontrada no epitélio que recobre as placas de "Peyer", especializadas em capturar antígenos da luz intestinal e apresentá-los para as células do sistema linfático associado ao intestino (TRABULSI et al., 2004). A Salmonella enterica se prolifera no interior dos vacúolos das células do retículo endotelial, desta forma pode atingir 
diferentes órgãos e tecidos do hospedeiro, levando à infecção sistêmica (SALYERS, A.A. \& WHITT, D.D.1994).

A maioria das sorovariedades de Salmonella não tifóides morre rapidamente nos sítios extraintestinais, assim a infecção mais comum ou gastroenterite permanece limitada ao intestino. Somente as cepas que permanecem na mucosa intestinal são associadas com as infecções agudas e diarréia. A diarréia ocorre devido à alta secreção de eletrólitos pelos intestinos (TRABULSI et al 2004).

Para se disseminar, as bactérias escapam da parte basal do epitélio para dentro da lâmina própria, levando à febre entérica. Após a invasão da mucosa ocorre a ativação da adenilato ciclase, induzindo a produção local de prostaglandinas e outros mediadores da reação inflamatória (MURRAY, P.R. et al., 1998). A figura 11 apresenta o processo de interação epitelial da Salmonella,demonstrando as etapas de adesão, penetração, colonização, secreção de água e eletrólitos levando ao quadro diarréico, além do sistema de disseminações da resposta infamatória.

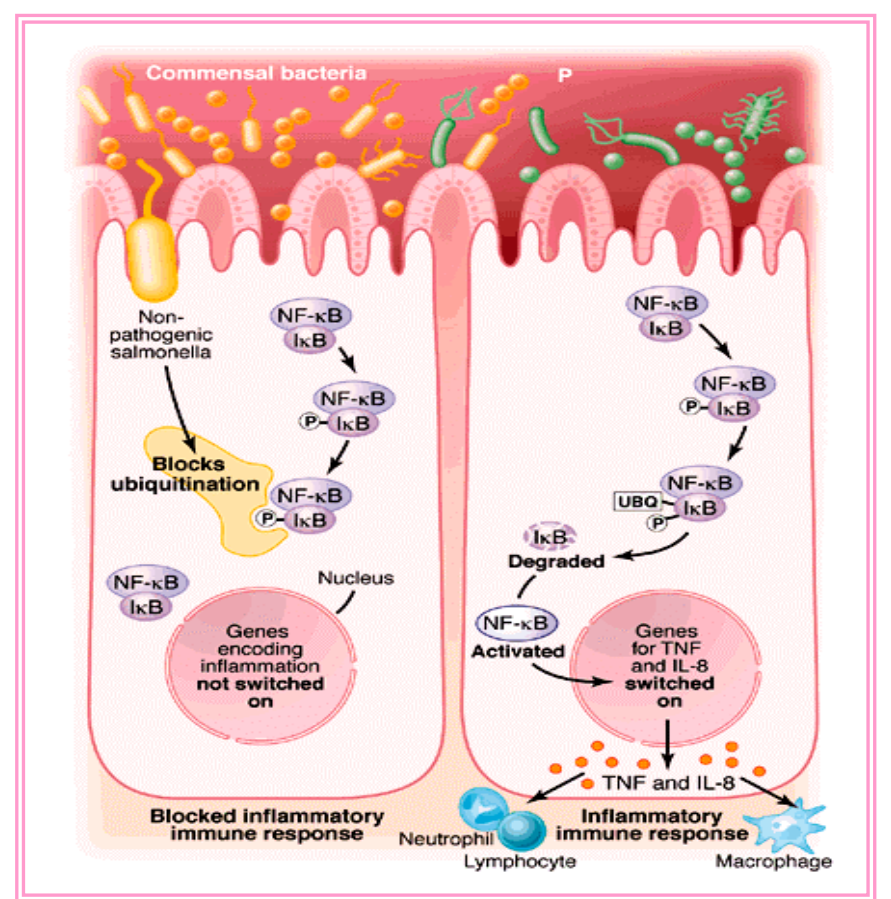

Figura 11 - Mecanismo de patogenicidade da Salmonella sp. Fonte: www.surrey.ac.uk/SBMS/ ACADEMICS_homepage/mcfa... $440 \times 551$ pixels - 64k 


\section{OBJETIVOS}

Avaliar a ação inibitória da quitosana sobre os enteropatógenos Salmonella enterica, Shigella sonnei e Escherichia coli EPEC, para isto serão testados:

- O crescimento dos enteropatógenos em meio ágar MacConkey

nas faixas de pH 5,0 por ser o mais eficiente para a ação inibitória da quitosana e pH7,4 por ser o padrão para o crescimento das bactérias utilizadas.

- Avaliação da reação de precipitação da quitosana em pH superior a 5,0 .

- Concentração inibitória mínima pelo método da diluição de duas soluções de quitosana de diferentes procedências, comercial (derivada de camarão), preparada no laboratório (derivada de lula).

- Concentração bactericida mínima a partir do plaqueamento ou subcultura em ágar MacConkey, pH 7,4 de todas as suspensões da Concentração inibitória mínima que não apresentarem turvação visível. 



\section{MATERIAIS E MÉTODOS}

\subsection{MEIOS DE CULTURA}

No laboratório, o crescimento bacteriano é obtido através de meios de cultura artificiais, cuja composição química deve atender às exigências nutricionais e físicas de cada bactéria de interesse. Não é possível confeccionar um meio de cultura universal dada à grande variedade nutritiva, portanto para a confecção dos meios é necessário conhecer a fisiologia das bactérias.

Os meios são divididos em duas categorias nutritivas, os sintéticos e os complexos. Os sintéticos apresentam uma composição química qualitativa e quantitativa conhecida, com nitrogênio e íons inorgânicos, sendo a fonte de carbono o $\mathrm{CO}_{2}$ atmosférico e a energia, a solar. Assim estes meios devem ser incubados em aerobiose e em presença de luz. Estes proporcionam o crescimento de bactérias fotolitotróficas. Os meios sintéticos podem ser acrescidos de uma fonte orgânica de energia e carbono (glicose) permitindo o crescimento de bactérias quimioorganotróficas.

Os meios complexos apresentam uma composição química não definida, através do acréscimo de substâncias nutritivas, como extrato de carne, vitaminas, peptonas ou ainda sangue, soro, entre outros, extrato de leveduras, extratos de órgãos animais como fígado, coração, extratos de vegetais como soja de arroz. Estes meios destinam-se ao cultivo de bactérias mais exigentes nutricionalmente.

Os meios de cultura também podem ser diferenciados segundo à consistência desejada. Podem ser líquidos, semi-sólidos e sólidos. A substância solidificante utilizada é o ágar bacteriológico comercial, extraído de algas marinhas. Na concentração de 12 a $15 \%$ de ágar obtemos os meios sólidos, com a finalidade de promover o crescimento de colônias isoladas para 
estudo morfológico, contagem e identificação. Estes podem ainda variar quanto à distribuição nos tubos de ensaio, através de superfície inclinada sem base para aerobiose, superfície reta para inoculação em profundidade ou anaerobiose, e superfície inclinada com base para anaeróbios facultativos.

Os meios semi-sólidos são destinados à pesquisa rotineira da motilidade bacteriana, através da turvação desenvolvida pelo agente no meio a partir do ponto da área de inoculação. Estes apresentam na sua composição a concentração de 3 a 4\% de ágar bacteriológico comercial.

Os meios de cultura líquidos não têm ágar bacteriológico, exceto quando o objetivo é inibir a difusão de oxigênio. Neste caso, a concentração de ágar é muito reduzida de $0,075 \%$, não interferindo na consistência líquida. Estes meios permitem uma absorção mais rápida de nutrientes e permitem um aumento em número da população, a qual é caracterizada pela turbidez apresentada.

Os meios de cultura podem ainda ser classificados quanto à composição química em simples ou comum ou básico, capaz de permitir o crescimento de bactérias pouco exigentes, e a partir dele pelo acréscimo de substâncias tóxicas levando à seletividade e ao acréscimo de substâncias nutritivas levando à condição de crescimento de bactérias mais exigentes (BARON \&FINEGOLD, 1990).

Para a confecção da maioria dos meios de cultura artificiais é preciso:

- separar todo material a ser utilizado na preparação dos meios desejados,

- pesar a quantidade adequada ao volume que será confeccionado

- transferir o meio para um balão volumétrico de fundo chato adequado ao volume a ser preparado,

- acrescentar com uma proveta o volume de água destilada e deionizada para o volume do meio a ser preparado,

- homogeneizar bem,

- aquecer o meio com agitação constante até atingir 1minuto de fervura,

- vedar o balão com algodão, cobri-lo com gaze e por último, papel alumínio.

- autoclavar a $121^{\circ} \mathrm{C}$ por 15 minutos,

- depois de esterilizado o meio deve esfriar até $50^{\circ} \mathrm{C}$ para ser distribuído em placas e em tubos,

- checar o pH com o auxílio da fita indicadora de pH, antes da distribuição. 


\subsubsection{MEIOS DE CULTURA UTILIZADOS}

\subsubsection{1 Ágar MacConkey}

Este meio é amplamente utilizado para isolar e identificar, seletivamente enterobactérias em amostras biológicas, assim como águas de esgotos e alimentos. A mistura de sais biliares e o cristal violeta são responsáveis pela inibição das bactérias Gram positivas. Algumas bactérias Gram positivas podem crescer num número bastante reduzido neste meio, como Enterococcus faecalis, e alguns estafilococos, formando colônias puntiformes. O MacConkey é utilizado no isolamento dos enteropatógenos a partir do material fecal dos pacientes $O$ mesmo meio foi utilizado na investigação do crescimento dos enteropatógenos nas faixas de pH 5,0 e 7,4.

A composição está apresentada na tabela 4.

Tabela 4 - COMPOSIÇÃO DO ÁGAR MacConkey

\begin{tabular}{|l|l|}
\hline Peptona & $20,0 \mathrm{~g} \mathrm{~L}^{-1}$ \\
\hline Lactose & $10,0 \mathrm{~g} \mathrm{~L}^{-1}$ \\
\hline Sais biliares & $5,0 \mathrm{~g} \mathrm{~L}^{-1}$ \\
\hline Cristal violeta & $0,001 \mathrm{~g} \mathrm{~L}^{-1}$ \\
\hline Cloreto de sódio & $5,0 \mathrm{~g} \mathrm{~L}^{-1}$ \\
\hline Vermelho neutro & $0,075 \mathrm{~g}^{-1} \mathrm{~L}$ \\
\hline Ágar & $12,0 \mathrm{~g} \mathrm{~L}^{-1}$ \\
\hline Água destilada q.s.p. & $1000 \mathrm{~mL}^{-}$ \\
\hline pH final: $7,4 \pm 0,2$ &
\end{tabular}

Fonte: BIOBRÁS

\subsubsection{2. Ágar SS para Salmonella e Shigella}

O meio ágar SS apresentado na tabela 5 é altamente seletivo, formulado para inibir o crescimento da maioria dos microrganismos coliformes e permitir o crescimento de Salmonella e Shigella de amostras de fezes, urina e alimentos frescos ou enlatados. A mistura de sais biliares é responsável pela inibição das bactérias Gram positivas. Este meio é utilizado para obter o isolamento de Salmonella e Shigella a partir do plaqueamento direto do 
material fecal, assim como do plaqueamento do caldo de enriquecimento (subcultura). Deve ser incubado por 24 horas a $37^{\circ} \mathrm{C}$. A composição do meio de cultura está representada na tabela 4.

\section{Tabela 5 - COMPOSIÇÃO DO MEIO ÁGAR SS}

\begin{tabular}{|l|c|}
\hline Extrato de carne & $5,0 \mathrm{~g} \mathrm{~L}^{-1}$ \\
\hline Peptona & $5,0 \mathrm{~g} \mathrm{~L}^{-1}$ \\
\hline Lactose & $10,0 \mathrm{~g} \mathrm{~L}^{-1}$ \\
\hline Sais biliares & $8,5 \mathrm{~g} \mathrm{~L}^{-1}$ \\
\hline Citrato de sódio & $8,5 \mathrm{~g} \mathrm{~L}^{-1}$ \\
\hline Tiossulfato de sódio & $8,5 \mathrm{~g} \mathrm{~L}^{-1}$ \\
\hline Citrato férrico & $1,0 \mathrm{~g} \mathrm{~L}^{-1}$ \\
\hline Ágar bacteriológico & $12,5 \mathrm{~g} \mathrm{~L}^{-1}$ \\
\hline Vermelho neutro & $0,025 \mathrm{~g} \mathrm{~L}^{-1}$ \\
\hline Verde brilhante & $0,033 \mathrm{~g} \mathrm{~L}^{-1}$ \\
\hline Água destilada q.s.p. & $1000 \mathrm{~mL}^{-}$ \\
\hline pH final: $7,4 \pm 0,2$ & \\
\hline
\end{tabular}

Fonte: BIOBRÁS

\subsubsection{B.H.I. (BRAIN HEART INFUSION)}

O meio de cultura $\mathrm{BHI}$ é um caldo adequado para o cultivo de bactérias exigentes e não exigentes nutricionalmente. É utilizado para enriquecimento e na recuperação metabólica bacteriana. Por ser líquido e apresentar alto teor nutricional, favorece a absorção de nutrientes. A composição do meio está representada na tabela 6 .

Tabela6 - Composição do Brain Heart Infusion (BHI)

\begin{tabular}{|l|c|}
\hline $\mathrm{Na} \mathrm{Cl}$ & $5,0 \mathrm{~g} \mathrm{~L}^{-1}$ \\
\hline Dextrose & $2,0 \mathrm{~g} \mathrm{~L}^{-1}$ \\
\hline Fosfato bibásico de sódio & $2,5 \mathrm{~g} \mathrm{~L}^{-1}$ \\
\hline $\mathrm{BHI}$ & $17,5 \mathrm{~g} \mathrm{~L}^{-1}$ \\
\hline Peptona de carne & $5,0 \mathrm{~g} \mathrm{~L}^{-1}$ \\
\hline Peptona de caseína & $5,0 \mathrm{~g} \mathrm{~L}^{-1}$ \\
\hline Água destilada e deionizada q.s.p. & $1000 \mathrm{~mL}^{-}$ \\
\hline $\mathrm{pH}=6,8 \pm 0,2$ & \\
\hline
\end{tabular}

Fonte: DIFCO 


\subsubsection{4 ÁGAR MÜELLER HINTON}

O meio Müeller Hinton é rico nutricionalmente e é recomendado pela OMS (Organização Mundial de Saúde) para a realização de provas de sensibilidade. Este meio também é utilizado como base para confecção dos meios ágar sangue e ágar chocolate, para agentes bacterianos mais exigentes nutricionalmente. A composição deste está representada na tabela 7 .

Tabela 7 - Composição do meio Müeller Hinton

\begin{tabular}{|l|c|}
\hline Ágar bacteriológico & $17,0 \mathrm{~g} \mathrm{~L}^{-1}$ \\
\hline Amido de batata & $1,5 \mathrm{~g} \mathrm{~L}^{-1}$ \\
\hline Extrato de carne & $2,0 \mathrm{~g} \mathrm{~L}^{-1}$ \\
\hline Hidrolisado ácido de caseína & $17,5 \mathrm{~g} \mathrm{~L}^{-1}$ \\
\hline Água destilada e deionizada & $1000 \mathrm{~mL}$ \\
\hline $\mathrm{pH}=7,4 \pm 0,2$ & \\
\hline Fonte: BIOBRÁS &
\end{tabular}

\subsubsection{TUBO 0,5 DA ESCALA DE Mc FARLAND}

Para padronizar a densidade do inóculo para realização do teste de sensibilidade, foi usado como controle de turbidez uma solução padrão de McFarland 0,5, a qual apresenta uma turbidez compatível com uma suspensão bacteriana contendo aproximadamente 1 a $2 \times 10^{8}$ bactérias $/ \mathrm{mL}$ (anexo I). A composição do tubo 0,5 de Mc Farland está representada na tabela 8.

Tabela 8 - TUBO 0,5 DA ESCALA DE Mc FARLAND

\begin{tabular}{|l|r|}
\hline Cloreto de bário. $2 \mathrm{H}_{2} \mathrm{O} 0,048 \mathrm{~mol} / \mathrm{L}$ & $0,5 \mathrm{~mL}$ \\
\hline Ácido sulfúrico $0,36 \mathrm{~N}$ & $99,5 \mathrm{~mL}$ \\
\hline
\end{tabular}

Fonte: H. MÜLLER, 1941

\subsection{PREPARO DAS SOLUÇÕES}


Foram utilizadas duas soluções de quitosana nos experimentos, sendo uma solução de quitosana derivada de camarão (do tipo comercial Fluka) e a segunda derivada de lula.

A quitosana derivada de lula foi obtida no Laboratório de Bioquímica e Biomateriais do Instituto de Química de São Carlos, pelo doutorando, José Fernando Dagnone Figueiredo. A quitosana derivada de lula foi preparada na concentração de $0,5 \%$ em solução de ácido acético a $1 \%$, com peso molecular estimado em $10^{7} \mathrm{~g} \mathrm{~mol}^{-1}$, grau de desacetilação de $83 \%$ e pH 5,0.

As amostras de quitosana derivadas de camarão foram caracterizadas com o auxílio da aluna da iniciação científica, do Instituto de Química de São Carlos, USP, Rafaela Basso Montoro. A quitosana derivada de camarão foi preparada na concentração de $0,5 \%$ em solução acética a $1 \%$, com peso molecular de $600.000 \mathrm{~g} \mathrm{~mol}^{-1}$ grau de desacetilação de $76 \%$ e pH 5,0.

Os valores acima foram confirmados através de:

- análise de espectroscopia de absorção no infravermelho (IV),

- termogravimetria (TG/DTG),

- calorimetria exploratória diferencial (DSC),

- determinação do grau de acetilação por $\mathrm{H}^{1} \mathrm{RMN}$ (KURITA, K. et al 1993).

\subsection{OBTENÇÃO DOS ENTEROPATÓGENOS}

Os enteropatógenos foram isolados a partir de coprocultura pelo Laboratório de Microbiologia da Unidade de Emergência do Hospital das Clínicas da FMRP (HC-USP) e caracterizados molecularmente no Laboratório de Genômica e Biologia Molecular Bacteriana da Faculdade de Medicina de Ribeirão Preto da Universidade de São Paulo - USP. Estas amostras fazem parte de um Banco de Amostras, onde foram devidamente identificadas e armazenadas em solução de glicerol $5 \mathrm{~mol} \mathrm{~L}^{-1}$ em biofreezer a $-70^{\circ} \mathrm{C}$, e foram gentilmente cedidas pelo doutorando André Pitondo da Silva, com devida autorização dos responsáveis pelo Banco de Amostras. 
As amostras foram transportadas adequadamente e processadas no laboratório de Microbiologia do Centro Universitário Barão de Mauá.

As amostras dos enteropatógenos foram transferidas separadamente em condições de assepsia para tubos de ensaio contendo $5 \mathrm{~mL}$ de meio enriquecedor $\mathrm{BHI}$ estéril e incubadas por 12 horas a $37^{\circ} \mathrm{C}$. Após a incubação, as suspensões da Escherichia coli EPEC foram plaqueadas em ágar MacConkey (BIOBRÁS), enquanto que as suspensões de Salmonella enterica e de Shigella sonnei foram inoculadas separadamente em placas de ágar SS (BIOBRÁS), pH 7,4, por 24 horas a $37^{\circ} \mathrm{C}$ para a obtenção de colônias isoladas, a fim de submetê-las aos testes utilizados neste estudo.

As placas dos meios SS e MC, após a incubação, estão representadas nas figuras 12,13 e 14 .

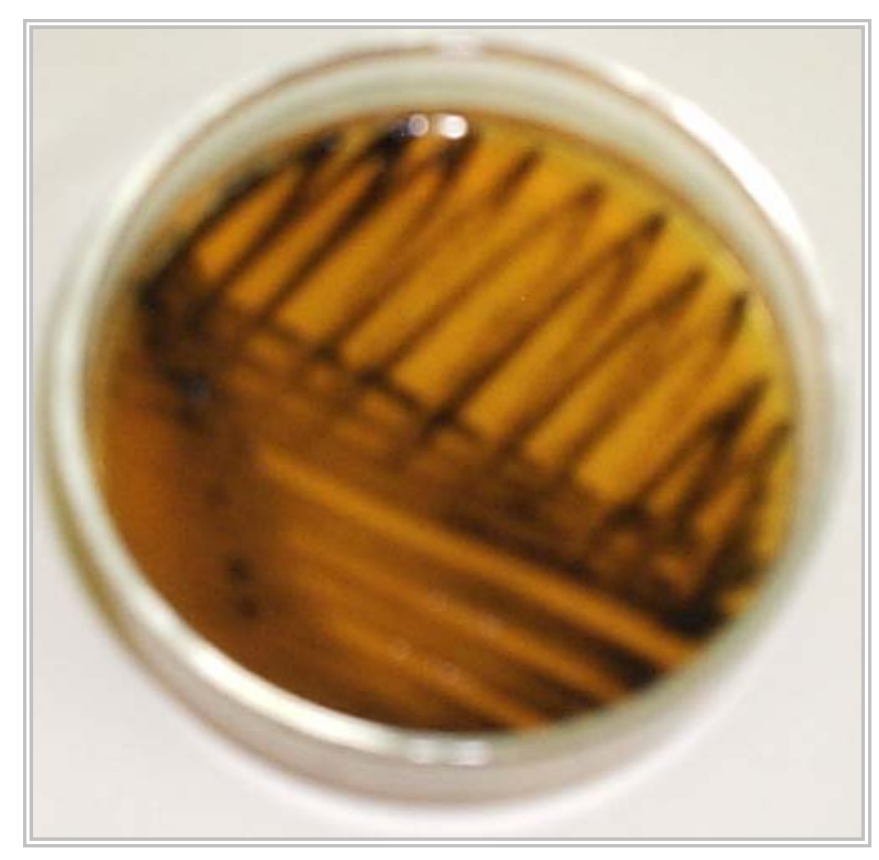

Figura: 12- Cultura pura de $24 \mathrm{~h}$ de S.enterica em ágar SS 


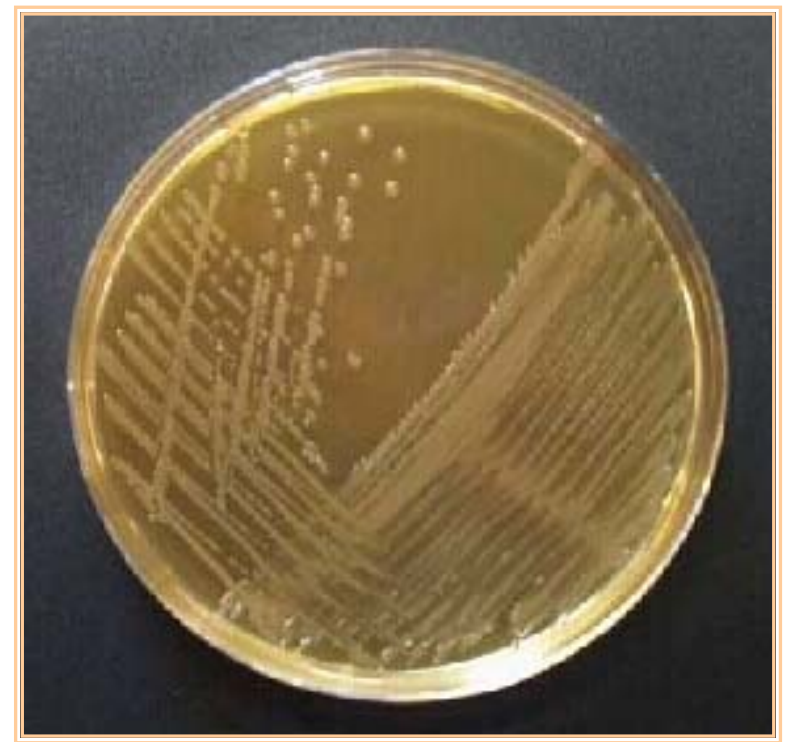

Figura 13 - Cultura pura de Shigella sonnei em ágar SS

Os gêneros Salmonella e Shigella no meio de cultura ágar MC apresentam colônias amarelas, ou seja, lactose negativa. O gênero Escherichia apresenta nos dois meios, colônias de cor rosa, ou seja, lactose positiva, como indicado na figura 14.

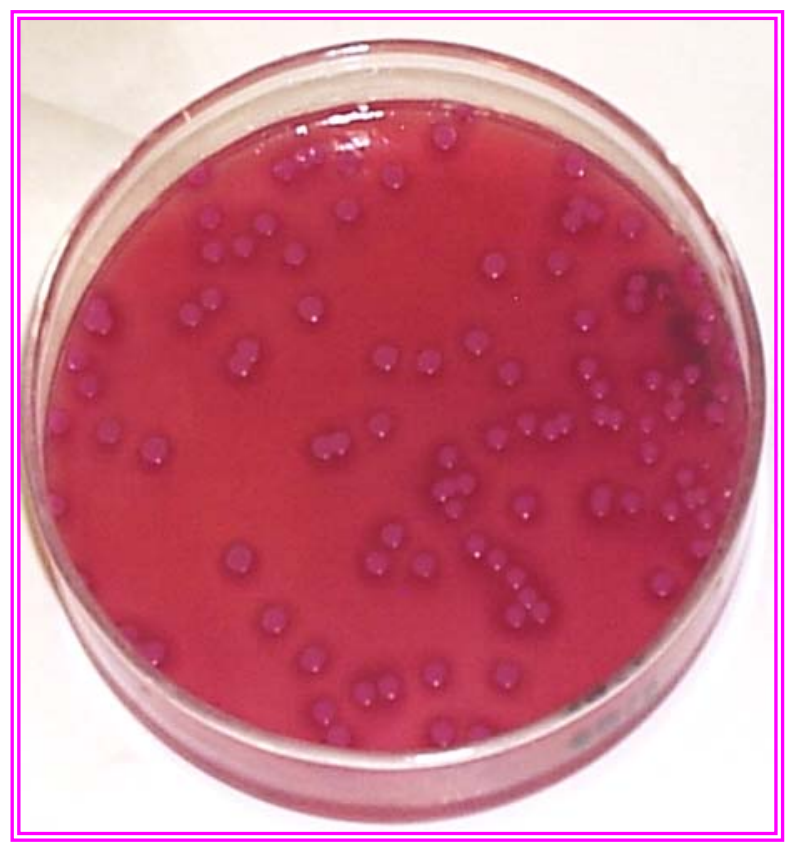

Figura 14 - Cultura pura de 24 horas de E.coli em ágar Mac Conkey 


\subsection{TESTES REALIZADOS}

\subsubsection{AVALIAÇÃO DO CRESCIMENTO DOS ENTEROPATÓGENOS EM ESTUDO EM MEIO MACCONKEY NAS FAIXAS DE pH 5,0 e 7,4.}

Alguns fatores foram essenciais na escolha do $\mathrm{pH}$ ideal para a realização deste estudo. Foram considerados os resultados reportados sobre a melhor atividade antimicrobiana da quitosana sobre bactérias gram positivas, gram negativas e fungos em pH ácido, (NO, H.K.; MEYERS, S.P., 1989; WANG, G., 1992; QI, L et al. 2004; TSAI, G.J., SU, W.H., 1999; YUN, Y.S., KIM, K.S., LEE, Y.N., 1999). O segundo fator avaliado foi a solubilidade, já que a quitosana é insolúvel em água, ácidos concentrados, álcalis, álcool e acetona e completamente solúvel em soluções de ácidos orgânicos, em pH menor que 6,0 (MATHUR, N.K., NARANG, K.C. 1990).

O terceiro fator, foi o pka da quitosana, que é de aproximadamente 6,5, portanto aumentando o $\mathrm{pH}$ das soluções acima deste valor ocorre precipitação na forma de flocos gelatinosos impossibilitando a leitura adequada da CIM (CHEN,R.H., 1996).

As amostras dos enteropatógenos foram transferidas do meio de conservação, solução de glicerol $5 \mathrm{~mol} \mathrm{~L}^{-1}$ para $5 \mathrm{~mL}$ de caldo $\mathrm{BHI}$, incubados a $37^{\circ} \mathrm{C}$ por 12 horas. As suspensões dos enteropatógenos foram plaqueados, sendo a E. coli em ágar MC, a Salmonella enterica e a Shigella sonnei em ágar SS, e incubados por 24 horas a $37^{\circ} \mathrm{C}$, como demonstrado na figura 15 . Após a incubação, para cada um dos enteropatógenos foi confeccionada uma suspensão em $5 \mathrm{~mL}$ de salina estéril, com auxílio de alça bacteriológica estéril.

As suspensões preparadas foram comparadas à turvação do tubo $\mathrm{n}^{\circ}$. 0,5 da escala de McFarland (1 a $2 \times 10^{8}$ Unidades formadoras de colônia por $\mathrm{mL}$ ), representada na tabela 8 . Após a homogeneização da suspensão, $100 \mu \mathrm{L}$ desta suspensão inicial, foram transferidos para um tubo estéril e somados a $0,9 \mathrm{~mL}$ de solução salina estéril, obtendo uma diluição 1:10. Este procedimento foi repetido após homogeneização da amostra para a obtenção da diluição 1:100 e 1:1000. A suspensão $1: 1000$ foi homogeneizada e $100 \mu \mathrm{L}$ desta foi inoculada em meio MacConkey em pH 5,0 e em MacConkey em pH 7,4. A 
inoculação de $100 \mu \mathrm{L}$ de cada uma das suspensões foi realizada com alça estéril em oito campos sobrepostos para obtenção de crescimento isolado e homogêneo das colônias. Este recurso permite que a contagem do número das colônias seja feita com maior exatidão. Os meios de cultura foram incubados a $37^{\circ} \mathrm{C}$ por 24 horas.

Para o controle negativo dos meios, foram incubados duas placas de ágar MacConkey, sendo uma em pH 5,0 e uma em pH 7,4, por 72 horas a $37^{\circ} \mathrm{C}$. Estes foram lidos a cada $24 \mathrm{~h}$ de incubação e reincubados até completar às 72 horas.

Após a incubação foi realizada a leitura do crescimento do número de colônias nos meios utilizados como indicado na figura 16.

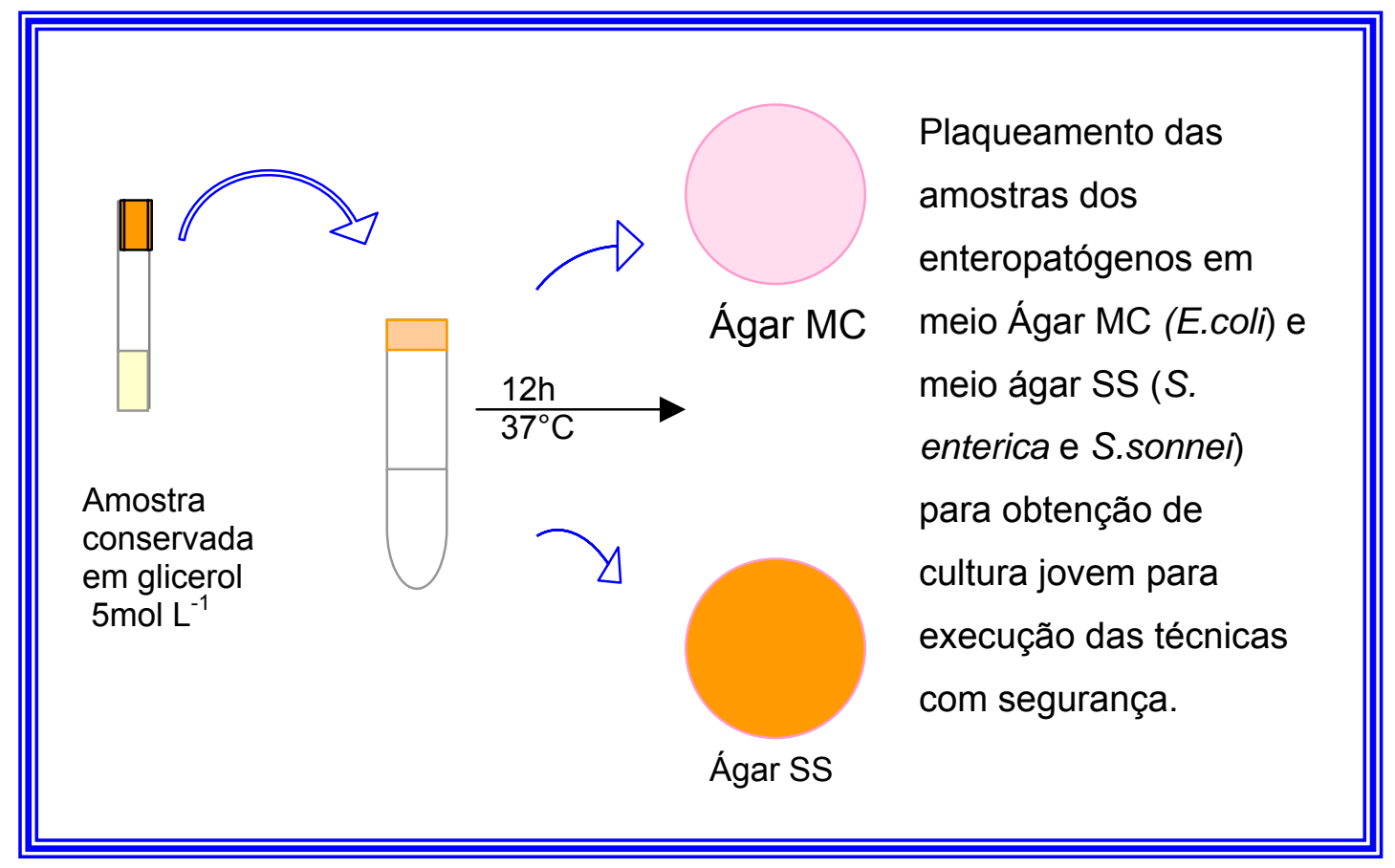

Figura 15 - Recuperação metabólica e obtenção de cultura jovem das amostras dos enteropatógenos provenientes do Banco de Amostras (USP - Ribeirão Preto)

Após a avaliação do crescimento dos enteropatógenos nas faixas de $\mathrm{pH} 5,0$ e pH 7, 4, foi então preparada uma nova subcultura de 24horas com a finalidade de obter população jovem em condições metabólicas ótimas na execução das técnicas a serem realizadas para testar a ação inibitória das soluções de quitosana derivadas de camarão e de lula. 


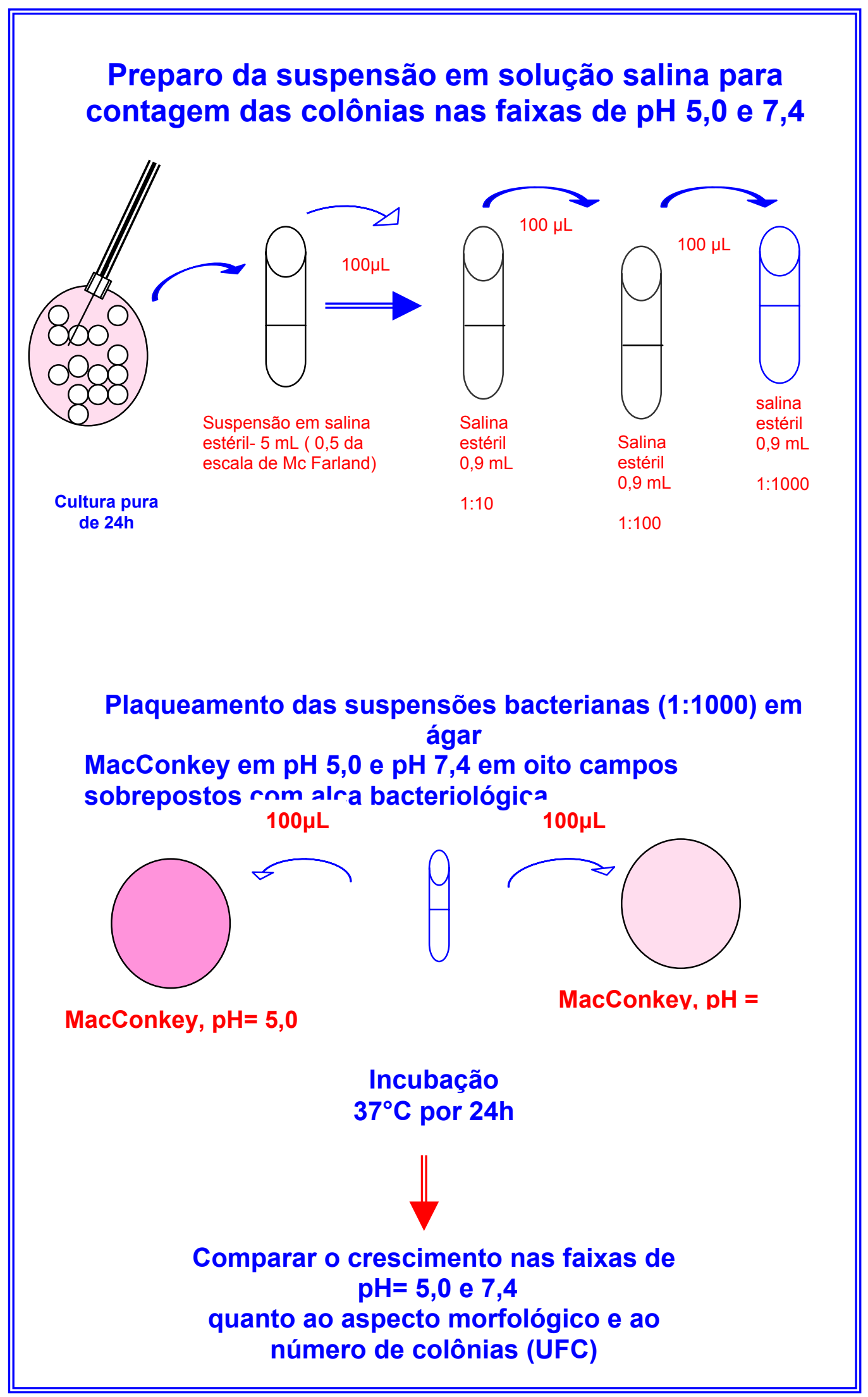

Figura 16 - Avaliação do crescimento dos enteropatógenos em meio MC em pH 5,0 e $\mathrm{pH} 7,4$ 


\subsubsection{AVALIAÇÃO DA REAÇÃO DE PRECIPITAÇÃO DA SOLUÇÂO DE QUITOSANA DERIVADA DE CAMARÃO E SOLUÇÃO DE QUITOSANA DERIVADA DE LULA EM pH 4,0; 5,0; 6,0; 7,0 e 8,0.}

A quitosana é solúvel em meios ácidos, forma soluções viscosas, sua solubilidade está relacionada com a quantidade de grupos protonados $\left(\mathrm{NH}_{3}{ }^{+}\right)$ presentes na sua estrutura química. Considerando-se que o pka dos grupos $\left(\mathrm{NH}_{3}{ }^{+}\right)$é de aproximadamente 6,5, aumentando $\mathrm{o} \mathrm{pH}$ das soluções de quitosana acima deste valor ela passa a sofrer reação de precipitação passando a se apresentar na forma de flocos gelatinosos (CHEN,R.H., 1996, MUZZARELLI, 1973).

Para a visualização da reação de precipitação da quitosana derivada de camarão e quitosana derivada de lula foram montadas séries com variação da faixa de pH entre 4,0 e 8,0. Cada série composta por cinco tubos de ensaio contendo cada um deles $5 \mathrm{~mL}$ de caldo Müeller Hinton estéril, o qual teve o $\mathrm{pH}$ ajustado em : 4,0; 5,0; 6,0;7,0 e 8,0.

controles

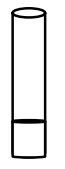

$\mathrm{CQ}$

$5 \mathrm{~mL}$

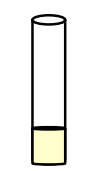

$\mathrm{C} \mathrm{MHB}$

$5 \mathrm{~mL}$

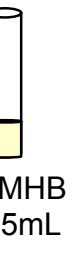

$\mathrm{MHB} \mathrm{pH}=$

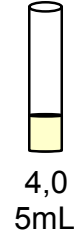

Série com caldo MH estéril
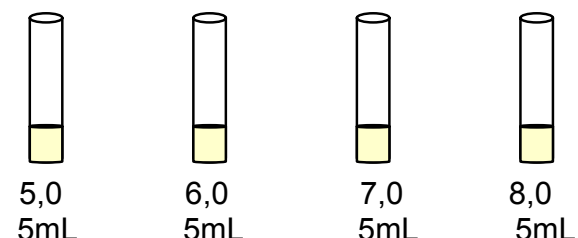

Adição de solução de quitosana (v/v)

Leitura através da presença ou não de precipitação
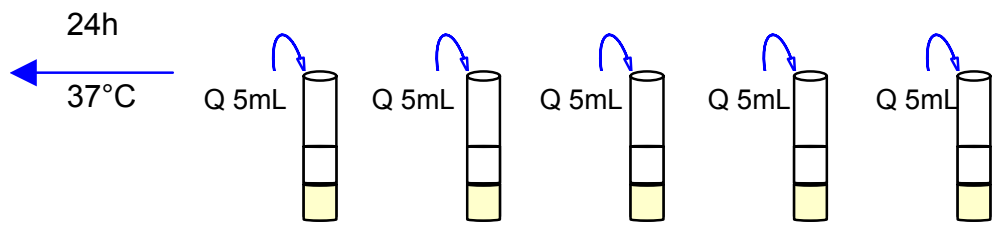

- Homogeneização das soluções

$\mathrm{CQ}=$ controle da solução de quitosana

$\mathrm{CMHB}=$ controle do caldo Müeller Hinton

$\mathrm{Q}=$ solução de Quitosana

$\mathrm{MHB}=$ Caldo Müeller Hinton

Figura 17 - Esquema da reação de precipitação da quitosana em pH acima de 6,5 
A seguir foi acrescentado o mesmo volume da solução de quitosana derivada de camarão e derivada de lula em cada série, respectivamente. As séries foram incubadas por 24 horas a $37^{\circ} \mathrm{C}$ para a realização da leitura, como demonstrado na figura 17.

\subsubsection{AVALIAÇÃO DA CONCENTRAÇÃO INIBITÓRIA MÍNIMA (CIM) DE QUITOSANA DERIVADA DE CAMARÃO E QUITOSANA DERIVADA DE LULA PELO MÉTODO DA DILUIÇÃO PARA OS ENTEROPATÓGENOS EM ESTUDO.}

Para a avaliação da CIM foi empregada a técnica de diluição seriada, e esta feita em triplicata para cada um dos enteropatógenos para confirmação dos resultados, baseado no método de QI. LIENG, et al., 2004.

O meio de cultura utilizado para o teste foi o caldo Müeller Hinton (MHB, BIOBRÁS), o qual teve seu pH ajustado em 5,0.

O MHB foi então distribuído em tubos de ensaio, $5 \mathrm{~mL}$ para cada tubo e em seguida autoclavado a $121^{\circ} \mathrm{C}$ por 15 minutos, como demonstrado na figura 18 .

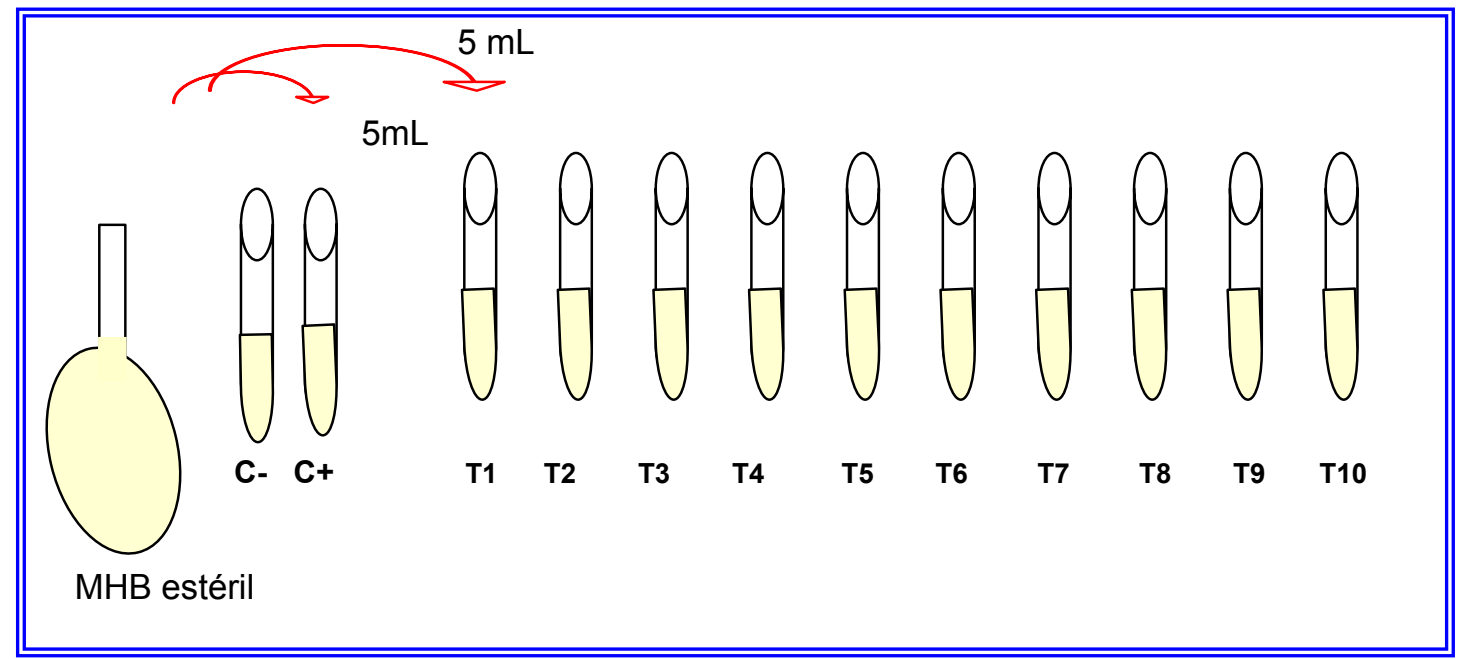

Figura: 18 - Distribuição do MHB nos tubos de ensaio para avaliação da CIM $\mathrm{C}-=$ Controle negativo (MHB estéril)

C+ = Controle positivo bacteriano (MHB contendo suspensão padrão, 0,5 de McFarland). 
A seguir foi feito o acréscimo da solução de quitosana, sendo $5 \mathrm{~mL}$ da solução no primeiro tubo. A solução foi então bem homogeneizada e $5 \mathrm{~mL}$ dela são transferidos para o tubo seguinte. O processo se repete até o décimo tubo e os $5 \mathrm{~mL}$ deste último tubo foram então desprezados como indicado na figura 19. O (C-) é o controle negativo da solução de quitosana derivada de lula ou da solução de quitosana derivada de camarão, portanto não sofreram nenhum acréscimo. O tubo $(\mathrm{C}+)$ é o controle positivo do enteropatógeno utilizado no teste.

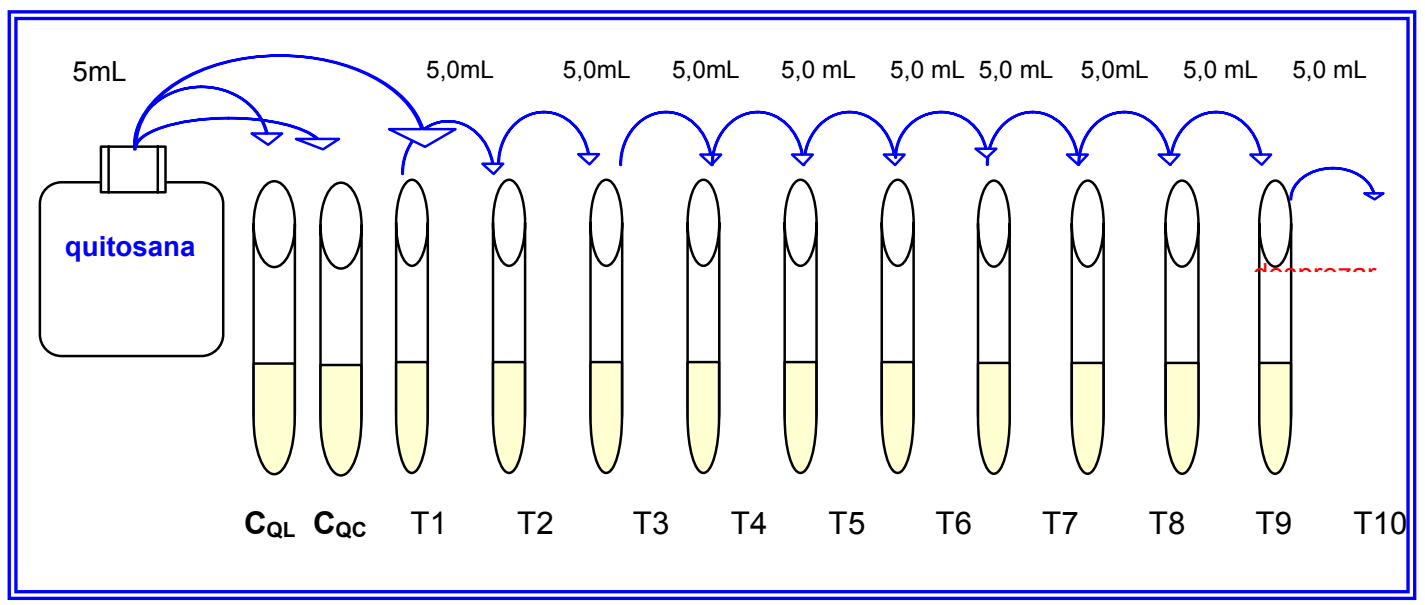

Figura: 19 - Acréscimo da solução de quitosana pH 5,0 seriada

$\mathrm{C}_{\mathrm{QL}}=$ Controle da solução de quitosana derivada de lula

$\mathrm{C}_{\mathrm{QC}}=$ Controle da solução de quitosana derivada de camarão

Tabela 9 - DILUIÇÕES E CONCENTRAÇÕES APROXIMADAS DAS SOLUÇÕES DE QUITOSANA

\begin{tabular}{l|l|c}
\hline $\mathrm{N}^{0}$. do tubo & Diluições & Concentrações das soluções \\
\hline T1 & $1: 1$ & $0,25 \%$ \\
\hline T2 & $1: 2$ & $0,125 \%$ \\
\hline T3 & $1: 4$ & $0,0625 \%$ \\
\hline T4 & $1: 8$ & $0,0312 \%$ \\
\hline T5 & $1: 16$ & $0,0156 \%$ \\
\hline T6 & $1: 32$ & $0,0078 \%$ \\
\hline T7 & $1: 64$ & $0,0004 \%$ \\
\hline T8 & $1: 128$ & $0,0002 \%$ \\
\hline T1 & $1: 256$ & $0,0001 \%$ \\
\hline
\end{tabular}


Com o acréscimo da solução de quitosana obteve-se diluições de 1:1 até $1: 512$, e concentrações decrescentes variando entre $0,25 \%$ até $0,00005 \%$ desta solução, como indicado na tabela 9.

$\mathrm{Na}$ etapa seguinte foi preparada a suspensão bacteriana padrão, a partir de cultura recente, ou seja, cultura de 24 horas reisolada no meio MacConkey. Foi preparada em salina estéril a suspensão de cada patógeno e comparada ao tubo 0,5 da escala McFarland e $10 \mu \mathrm{L}$ dela foi acrescida a cada um dos dez tubos. O material foi bem homogeneizado e incubado a $37^{\circ} \mathrm{C}$ por 24horas, como representado na figura 20.

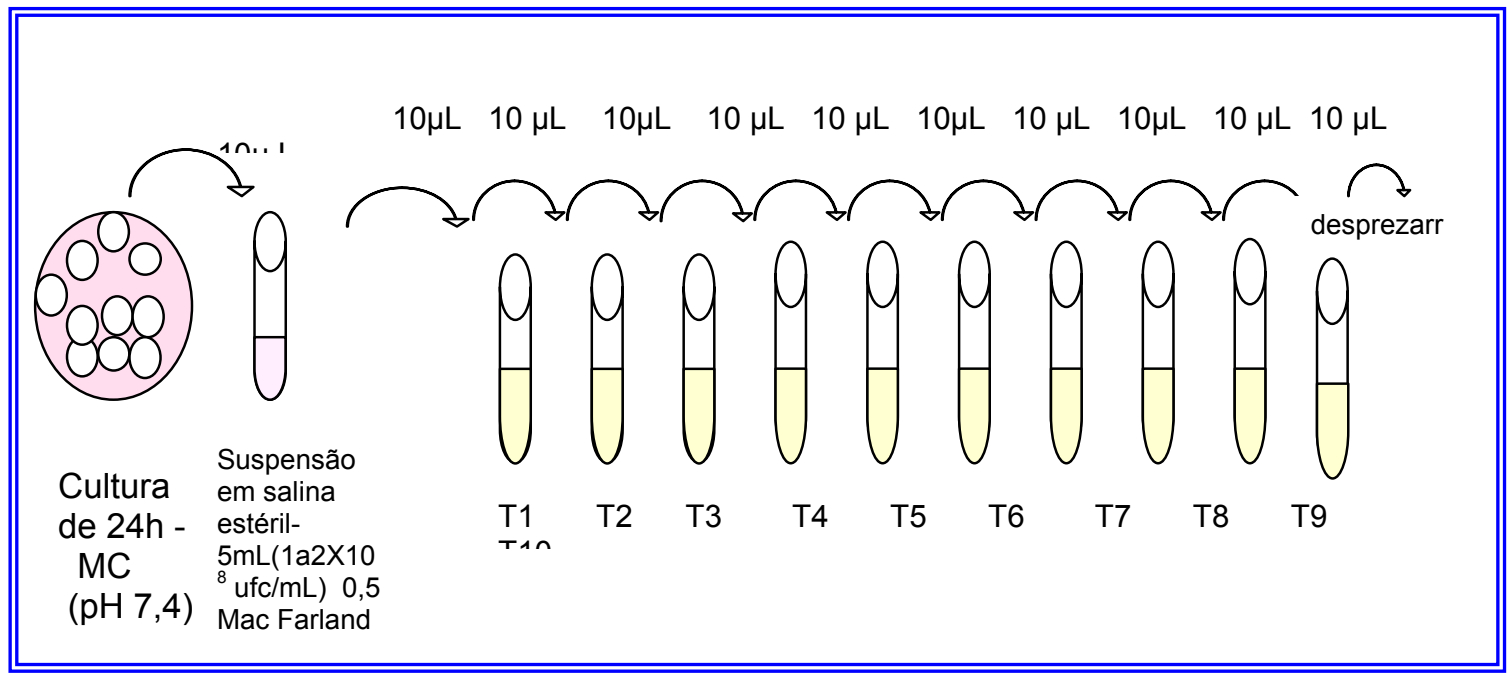

Figura: 20 - Preparo e acréscimo da suspensão bacteriana

As séries em triplicata dos enteropatógenos foram analisadas após incubação por 24 horas a $37^{\circ} \mathrm{C}$ para a determinação da concentração inibitória mínima (CIM) para a solução de quitosana derivada de camarão e para quitosana derivada de lula, como citado anteriormente.

\subsubsection{AVALIAÇÃO DA CONCENTRAÇÃO BACTERICIDA MÍNIMA (CBM) DE QUITOSANA DERIVADA DE CAMARÃO E QUITOSANA DERIVADA DE LULA PARA OS ENTEROPATÓGENOS EM ESTUDO PELO MÉTODO QUALITATIVO.}


Para a avaliação da Concentração Bactericida Mínima (CBM) foi empregada a técnica qualitativa em triplicata, baseado no método de QI, LIENG, etal. 2004. As séries utilizadas para a determinação da CIM foram usadas para a avaliação da CBM das soluções de quitosana derivada de camarão e solução de quitosana derivada de lula. A partir da leitura da CIM das soluções estudadas para os enteropatógenos, todos os tubos das séries que não apresentaram turvação visível tiveram 10 $\mu \mathrm{L}$ plaqueados em ágar MacConkey (BIOBRÁS), pH 7,4 e incubados por 24 horas a $37^{\circ} \mathrm{C}$. A partir da incubação os meios foram analisados para observação da presença de crescimento ou não de colônias dos enteropatógenos nas placas de MacConkey, $\mathrm{pH}$ 7,4 como indicado na figura 21.

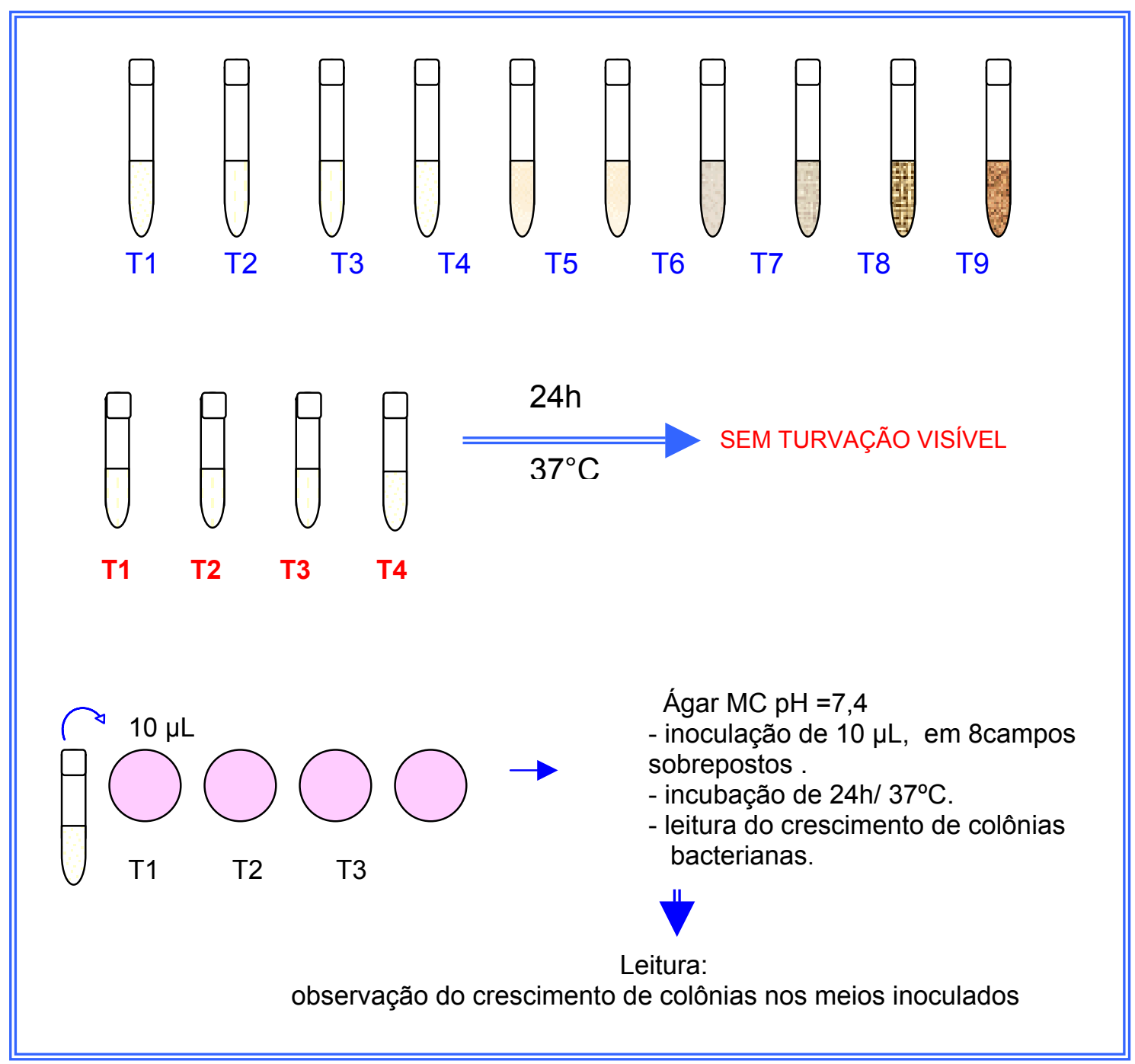

Figura 21 - Esquema da técnica para avaliação da Concentração Bactericida Mínima (CBM) das soluções de quitosana sobre os enteropatógenos. 
A leitura da CBM foi realizada através da visualização do crescimento ou não de colônias nas placas de MC após a incubação das mesmas, como indicado na tabela 11. 


\section{RESULTADOS E DISCUSSÃO}

\subsection{PREPARO DAS SOLUÇÕES DE QUITOSANA}

A solução de quitosana derivada de lula foi preparada no Laboratório de Bioquímica e Biomateriais do Instituto de Química de São Carlos - USP, pelo doutorando José Fernando Dagnone Figueiredo. A concentração da solução é de $0,5 \%$ em solução de ácido acético a $1 \%$, com peso molecular estimado em $10^{7} \mathrm{~g} \mathrm{~mol}^{-1}$ grau de desacetilação de $83 \%$ e pH 5,0.

A solução de quitosana derivada de camarão, comercial (Fluka) foi preparada no Laboratório acima citado, por Rafaela Basso Montoro, aluna da Iniciação Científica. A solução foi preparada na concentração de $0,5 \% \mathrm{em}$ solução acética a $1 \%$ com peso molecular de $600.000 \mathrm{~g} \mathrm{~mol}^{-1}$, grau de desacetilação de $76 \%$ e pH 5,0.

A maioria dos trabalhos tem reportado que os resultados mais eficientes da ação inibitória da quitosana sobre os diferentes tipos de microrganismos Gram positivos e Gram negativos ocorrem em pH ácido (NO, H.K.; MEYERS, S.P., 1989; WANG, G., 1992; LEE, S.H., JO, H.S., KIM, S.H., 1994; TSAI, G.J., SU, W.H., 1999; YUN, Y.S., KIM, K.S., LEE, Y.N., 1999).

\subsection{OBTENÇÃO DOS ENTEROPATÓGENOS}

As amostras dos enteropatógenos recebidas do Banco de Amostras em meio de conservação glicerol $5 \mathrm{Mol} \mathrm{L}^{-1}$, foram inoculadas em caldo $\mathrm{BHI} e$ incubadas por 12 horas a $37^{\circ} \mathrm{C}$ e subcultivadas em meios comerciais SS (S.enterica e S. sonnei) e MC (Escherichia coli enteropatogênica). A figura 22A apresenta o crescimento da amostra de Salmonella enterica no ágar SS (BIOBRÁS) a partir da subcultura, apresentando lactose negativa e $\mathrm{H}_{2} \mathrm{~S}$ positivo, 
característicos. A figura 22B mostra o crescimento da amostra de Shigella sonnei no ágar SS (BIBRÁS) a partir da subcultura, apresentando lactose e $\mathrm{H}_{2} \mathrm{~S}$ negativos característicos. A diferença entre Salmonella enterica e Shigella sonnei no meio de cultura SS (BIOBRÁS) é dada pela produção de $\mathrm{H}_{2} \mathrm{~S}$, o que torna as colônias da Salmonella escuras (pretas).

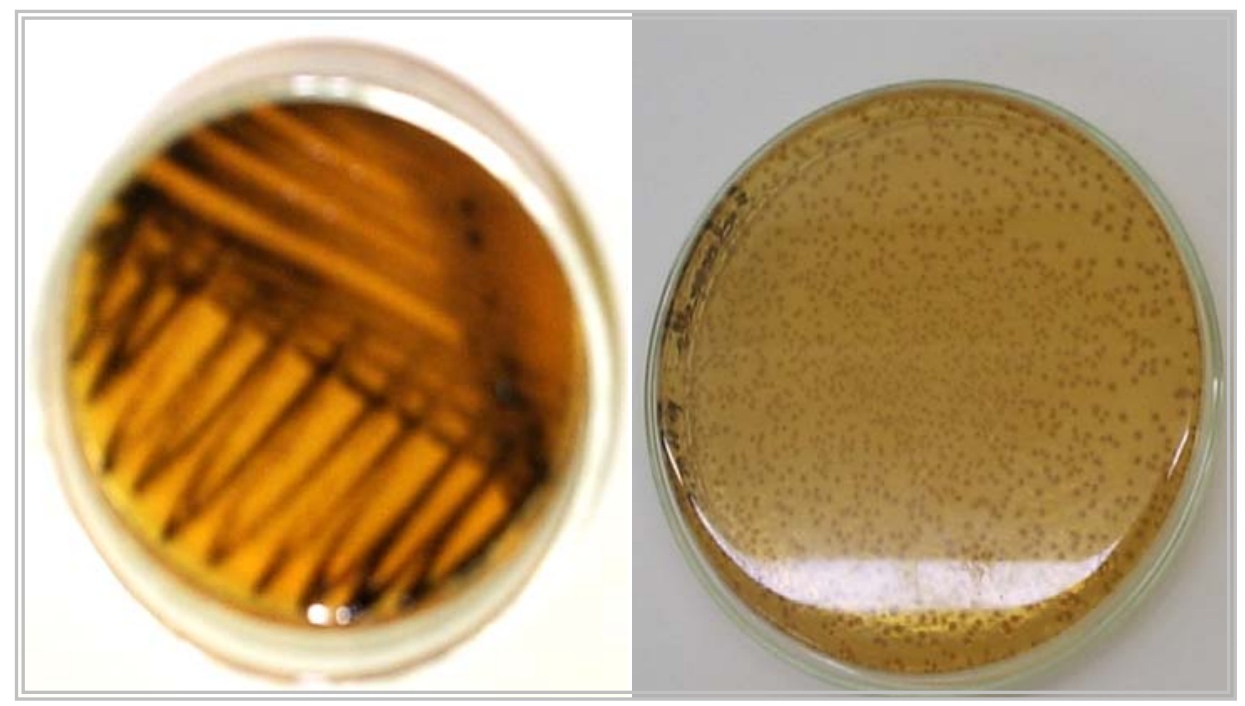

Figura 22A - Salmonella enterica em ágar SS (cultura de 24horas) 22B - Shigella sonnei em ágar SS (cultura de 24 horas)

A figura 23 mostra o crescimento da amostra de E.coli EPEC no meio ágar MacConkey (BIOBRÁS), a partir da subcultura, apresentando lactose positiva, caracterizada pela cor rosa forte.

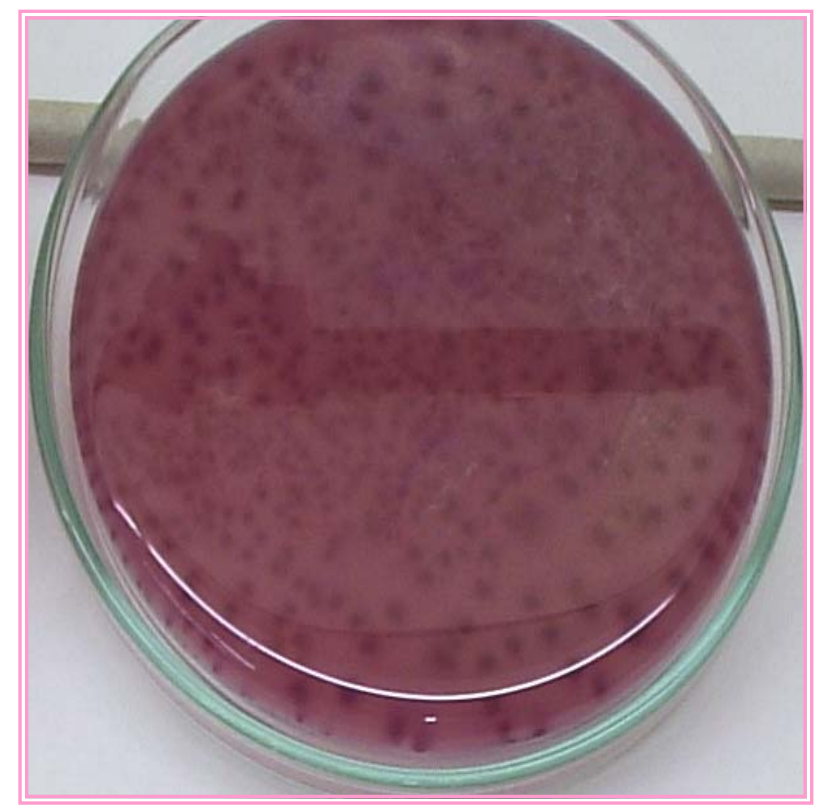


Figura 23 - Escherichia coli EPEC em ágar MacConkey (cultura de 24 horas)

\subsection{TESTES REALIZADOS}

\subsubsection{AVALIAÇÃO DO CRESCIMENTO DOS ENTEROPATÓGENOS EM ESTUDO EM MEIO MACCONKEY NAS FAIXAS DE pH 5,0 e 7,4.}

\subsubsection{Avaliação dos controles negativos do meio de cultura MacConkey e das soluções de quitosana derivada de camarão e derivada de lula nas faixas de $\mathrm{pH} 5,0$ e 7,4 .}

O meio MacConkey (BIOBRÁS) foi utilizado em pH 7,4, padrão indicado pelo fabricante do meio de cultura como sendo o $\mathrm{pH}$ ótimo para atividade metabólica de bactérias Gram negativas pouco exigentes. $\mathrm{O}$ pH 7,4 foi utilizado como referência do crescimento bacteriano esperado dentro das condições usuais, já que as técnicas utilizadas neste trabalho para avaliação da ação inibitória das soluções de quitosana estudadas no crescimento dos enteropatógenos foram feitas em pH 5,0, seguindo às referências da literatura sobre quitosana. Assim verificamos que a ação inibitória não foi dada pelo $\mathrm{pH}$ ácido do meio de cultura e sim pela ação inibitória da quitosana sobre os enteropatógenos. A maioria dos trabalhos reportados na literatura apresenta melhor atividade inibitória do crescimento bacteriano na faixa de acidez. TSAI, G.J. \& SU, W.H., 1999, demonstraram o aumento do efeito bactericida em $\mathrm{pH}$ ácido para $E$. coli , assim como, NO,H.K. et al, 2002, demonstraram que a ação CIM e CBM ocorre em pH $=5,0$, para bactérias Gram positivas e Gram negativas tendo testes realizados numa variação de $\mathrm{pH}$ entre 4,5 e 5,9. As figuras $24 \mathrm{~A}$ e 24B apresentam o meio MacConkey em $\mathrm{pH} 5,0 \mathrm{e} \mathrm{pH} \mathrm{7,4.} \mathrm{As} \mathrm{placas} \mathrm{foram} \mathrm{incubadas} \mathrm{sem} \mathrm{serem}$ inoculadas por $72 \mathrm{horas}$ a $37^{\circ} \mathrm{C}$ para controle de esterilidade do meio de cultura. Os controles negativos dos meios foram lidos a cada 24 horas até completar às 72 horas de incubação e nenhuma delas apresentou crescimento ou qualquer tipo de alteração, confirmando assim a esterilidade dos meios de cultura utilizados. A confirmação da esterilidade dos meios viabiliza a utilização destes para realização dos testes e leitura dos resultados apresentados pelos enteropatógenos. 


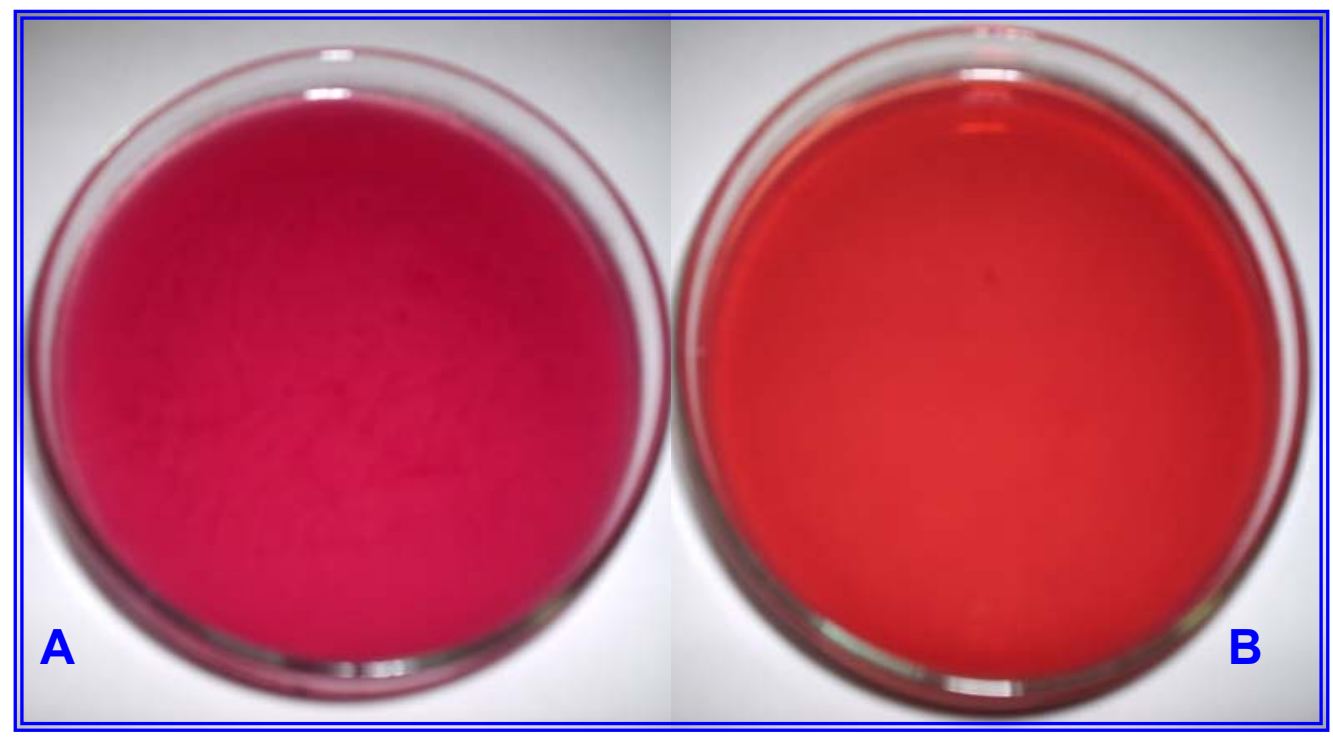

Figura 24A - Controle negativo do MacConkey em pH 5,0 24B - Controle negativo do MacConkey em $\mathrm{pH} 7,4$,

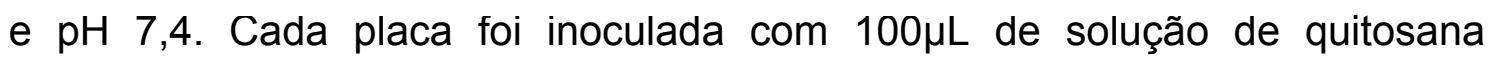
derivada de camarão para controle negativo da solução.

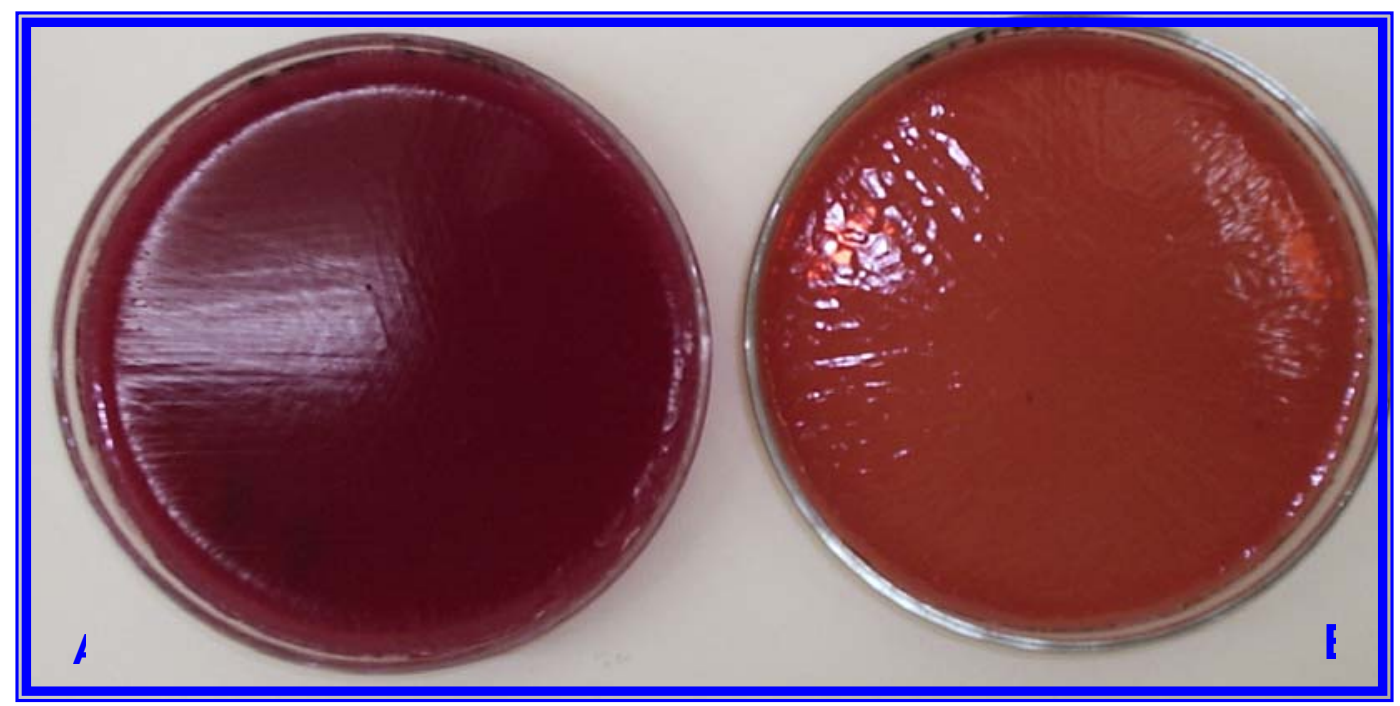

ÁGAR MC $\mathrm{pH}=5,0$

ÁGAR MC $\mathrm{pH}=7,4$

Figura 25A - Controle negativo da solução de quitosana derivada de camarão, $\mathrm{pH}=5,0$. $25 \mathrm{~B}$ - Controle negativo da solução de quitosana derivada de camarão, $\mathrm{pH}=7,4$. 
As placas foram incubadas por $72 \mathrm{horas}$ a $37^{\circ} \mathrm{C}$. Os controles negativos das soluções foram lidos a cada 24 horas até completar às 72 horas de incubação e nenhuma apresentou crescimento ou qualquer tipo de alteração.

As figuras 26A e 26B apresentam o meio ágar MacConkey em pH 5,0 e 7,4 . Cada placa foi inoculada com $100 \mu \mathrm{L}$ de solução de quitosana derivada de lula para controle negativo da solução. Foram incubadas por 72 horas a $37^{\circ} \mathrm{C}$. Os controles negativos das soluções foram lidos a cada 24 horas até completar às 72 horas de incubação e nenhuma apresentou crescimento ou qualquer tipo de alteração.

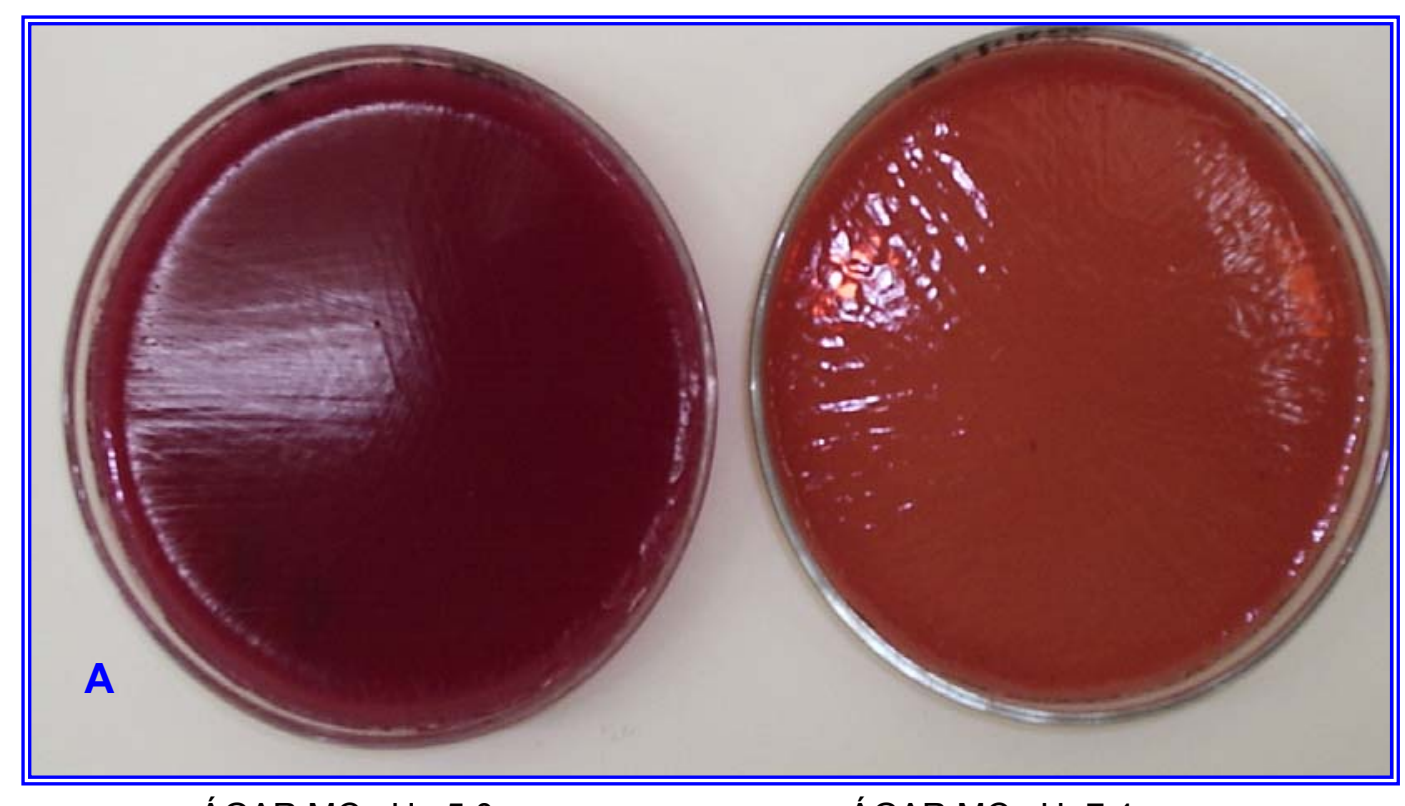

ÁGAR MC $\mathrm{pH}=5,0$

ÁGAR MC $\mathrm{pH}=7,4$

Figura 26A - Controle negativo da solução de quitosana derivada de lula em $\mathrm{pH}=5,0$. 26B - Controle negativo da solução de quitosana derivada de lula em $\mathrm{pH}=7,4$.

\subsubsection{Avaliação do controle positivo do crescimento dos enteropatógenos em estudo em meio ágar MacConkey nas faixas de pH 5,0 e 7,4.}

A figura 27A apresenta o controle positivo da Salmonella enterica em meio ágar MacConkey em pH 5,0 e figura 27B em pH 7,4. Estes meios foram inoculados com $100 \mu \mathrm{L}$ de suspensão de $S$. enterica preparada segundo o tubo 
0,5 da escala de Mc Farland. As placas foram incubadas a $37^{\circ} \mathrm{C}$ por 24 horas. $\mathrm{O}$ número de colônias se manteve constante nas duas faixas de $\mathrm{pH}$.

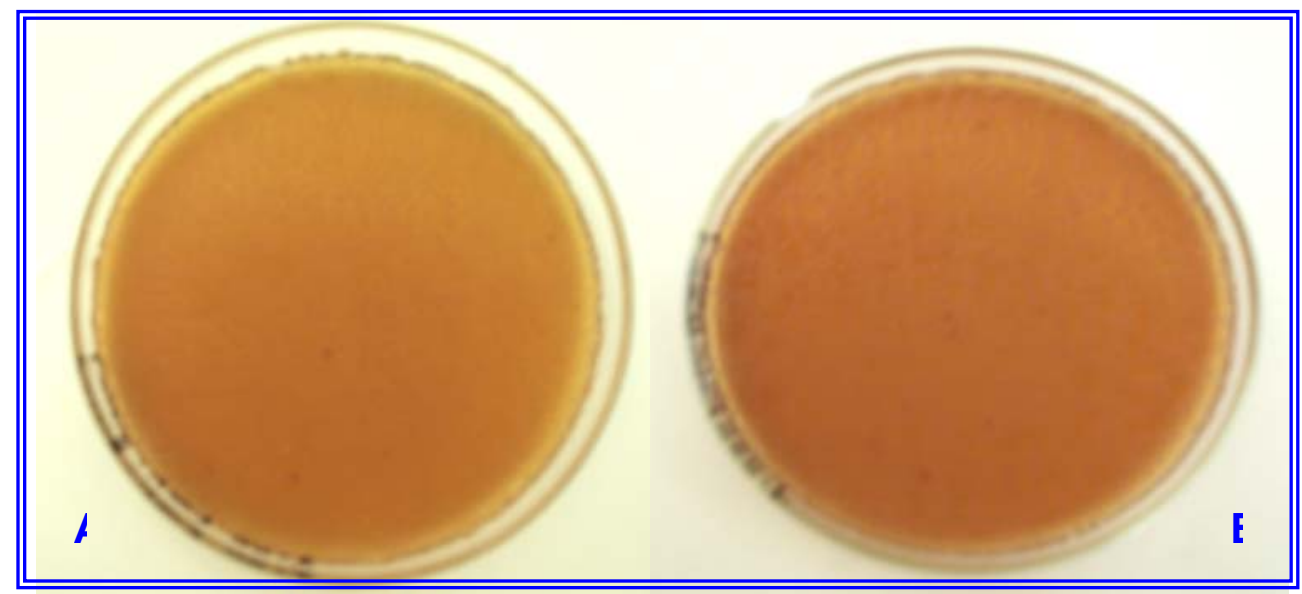

MacConkey $\mathrm{pH}=5,0$

S.enterica

MacConkey $\mathrm{pH}=7,4$

Figura 27A - controle positivo de S. enterica em ágar MacConkey em $\mathrm{pH}=5,0$. 27B - Controle positivo de S.enterica em ágar MacConkey em $\mathrm{pH}=7,4$.

A figura 28A apresenta o controle positivo da Shigella sonnei em meio ágar MacConkey em pH 5,0 e a figura 28B em pH 7,4. Estes meios foram inoculados com $100 \mu \mathrm{L}$ de suspensão de S. sonnei preparada segundo o tubo 0,5 da escala de Mc Farland. As placas foram incubadas a $37^{\circ} \mathrm{C}$ por 24 horas. $\mathrm{O}$ número de colônias se manteve constante nas duas faixas de $\mathrm{pH}$.

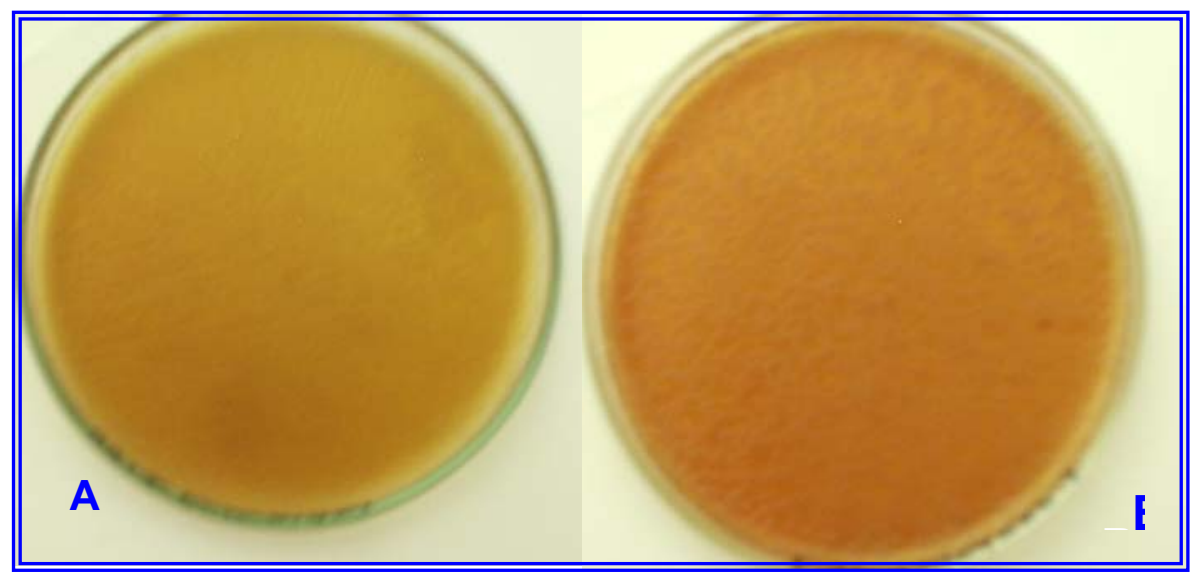

MacConkey $\mathrm{pH}=5,0$

S.sonnei MacConkey $\mathrm{pH}=7,4$

Figura 28A - Controle positivo de $\mathbf{S}$. sonnei em ágar MacConkey em $\mathrm{pH}=5,0$ 28B - Controle positivo de S. sonnei em ágar MacConkey em $\mathrm{pH}=7,4$. 
A figura 29A apresenta o controle positivo da Escherichia coli enteropatogênica em meio ágar MacConkey em pH 5,0 a figura 29B em pH 7,4. Estes meios foram inoculados com $100 \mu \mathrm{L}$ de suspensão de E. coli enteropatogênica preparada segundo o tubo 0,5 da escala de Mc Farland. As placas foram incubadas a $37^{\circ} \mathrm{C}$ por 24 horas. $\mathrm{O}$ número de colônias se manteve constante nas duas faixas de $\mathrm{pH}$.

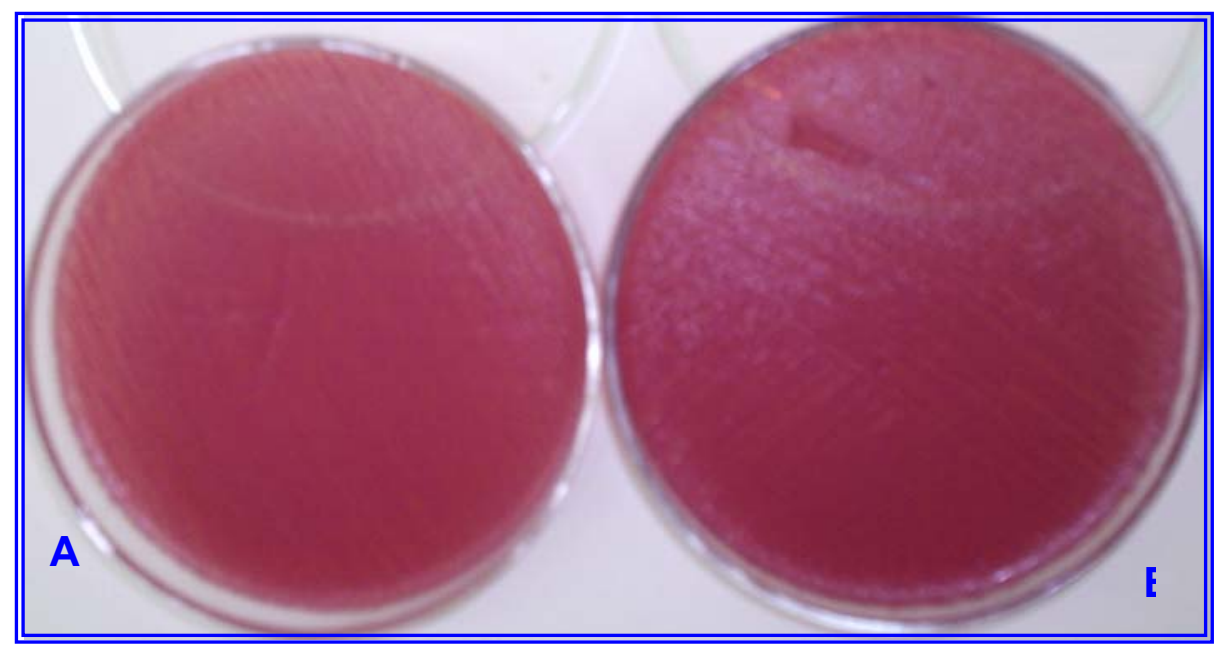

$$
\text { MacConkey } \mathrm{pH}=5,0 \quad \text { E.coli } \mathrm{EPEC} \text { MacConkey } \mathrm{pH}=7,4
$$

Figura 29A - Controle positivo de EPEC em ágar Mac Conkey em $\mathrm{pH}=5,0$ 29B - Controle positivo de EPEC em ágar MacConkey em $\mathrm{pH}=7,4$

Com estes experimentos pudemos assegurar que o $\mathrm{pH}$ ácido $(5,0)$ do meio de cultura (equivalente ao $\mathrm{pH}$ das soluções de quitosana utilizadas) não interfere no crescimento dos três enteropatógenos em estudo, inferindo assim que os resultados obtidos são exclusivamente da ação da quitosana frente aos enteropatógenos.

\subsubsection{Avaliação do número de colônias dos enteropatógenos em meio MacConkey em pH 5,0 e 7,4.}


A partir da obtenção do crescimento sem alterações frente a variação de $\mathrm{pH}$ utilizado, passamos a repetir o teste diluindo as suspensões dos enteropatógenos em 1:1000. Este procedimento possibilitou realizar a contagem do número de unidades formadoras de colônias em pH 5,0 e 7,4, uma vez que a suspensão original (0,5 da escala de Mc Farland) teve crescimento significativo, o suficiente parra forraras placas tornando impossível a contagem das colônias. A figura 30A apresenta o crescimento de Salmonella enterica em meio ágar MacConkey em pH 5,0 e a figura 30B em pH 7,4. Foram inoculados $100 \mu \mathrm{L}$ de suspensão 1:1000 do tubo 0,5 da escala de Mac Farland para contagem das colônias.

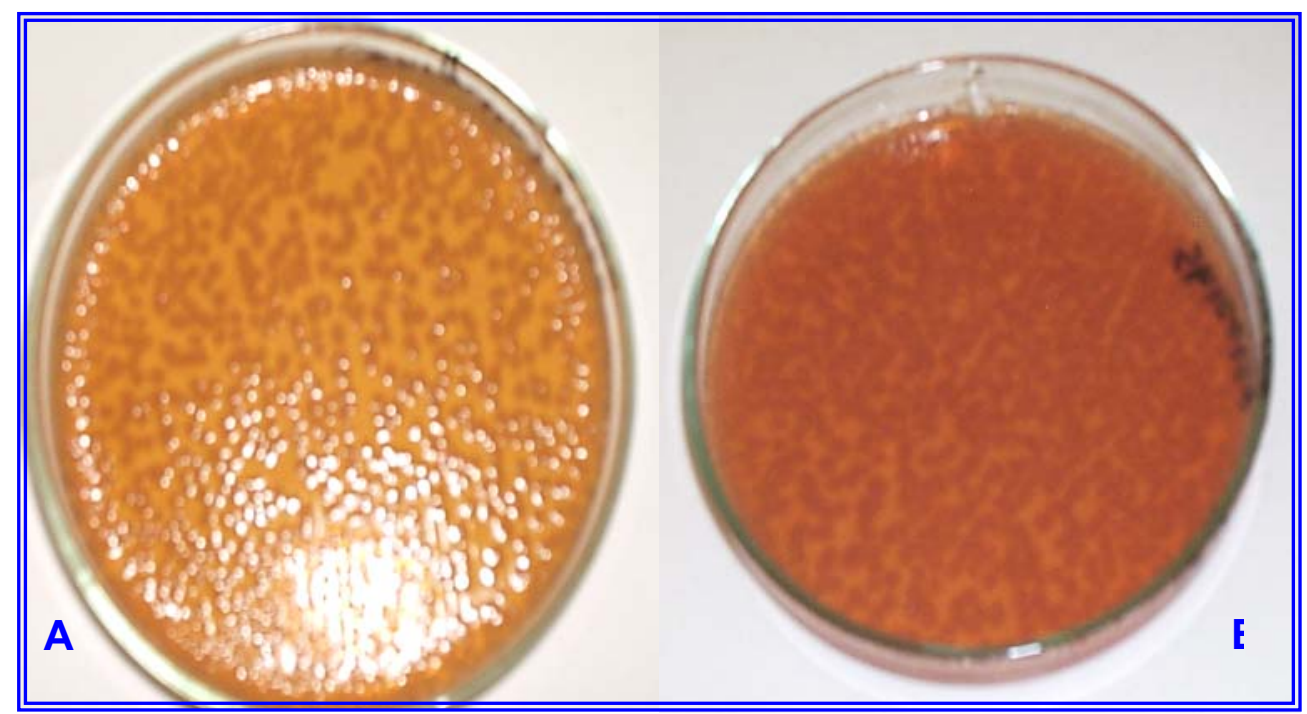

MacConkey pH 5,0

S.enterica

MacConkey pH 7,4

Figura 30A - Contagem do número de colônias de S. enterica em ágar MacConkey em $\mathrm{pH}=5,0$

30B - Contagem do número de colônias de S.enterica em ágar MacConkey em $\mathrm{pH}=7,4$

A figura 31A apresenta o crescimento de Shigella sonnei em meio ágar MacConkey em pH 5,0 e a figura 31B em pH 7,4. Foram inoculados $100 \mu \mathrm{L}$ de suspensão 1:1000 do tubo 0,5 da escala de Mac Farland para contagem das colônias. 


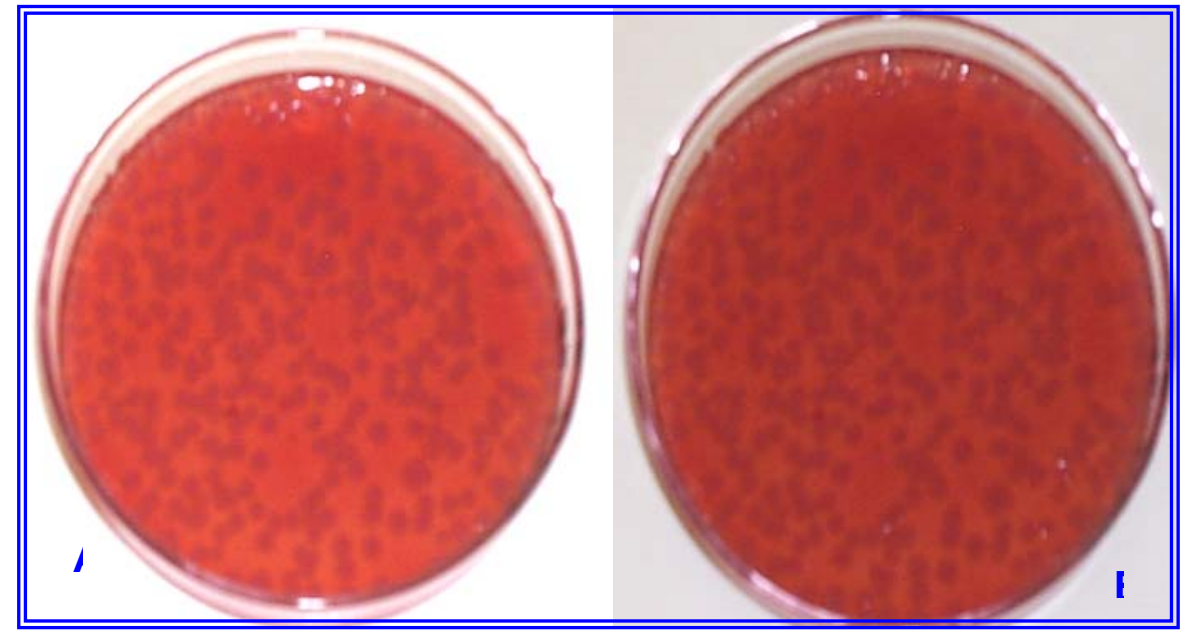

Mac Conkey pH 5,0

S.sonnei

Mac Conkey pH 7,4

Figura 31A - Contagem do número de colônias de $\mathrm{S}$. sonnei em ágar MacConkey em $\mathrm{pH}=5,0$

31B - Contagem do número de colônias de S.sonnei em ágar MacConkey em $\mathrm{pH}=7,4$

A figura 32A apresenta $\mathrm{O}$ crescimento de Escherichia coli enteropatogênica em meio ágar MacConkey em pH 5,0 e a figura 32B em pH 7,4. Foram inoculados $100 \mu \mathrm{L}$ de suspensão 1:1000 do tubo 0,5 da escala de Mc Farland para contagem das colônias.

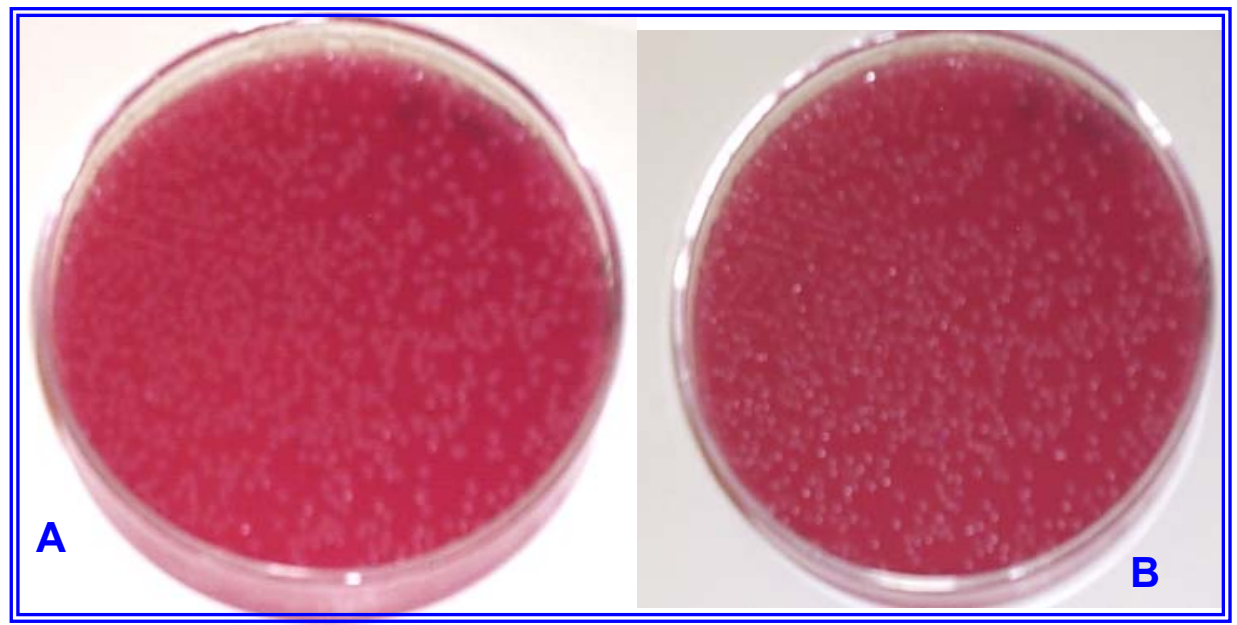

MacConkey $\mathrm{pH}$ 5,0 E coli EPEC MacConkey $\mathrm{pH} 7,4$

Figura 32A - Contagem do número de colônias de EPEC em ágar MacConkey em $\mathrm{pH}=5,0$.

32B - Contagem do número de colônias de EPEC em ágar MacConkey em $\mathrm{pH}=7,4$ 
A tabela 10 apresenta os resultados obtidos na pesquisa do número de colônias crescidas no meio MacConkey em pH 5,0 e em MacConkey em pH 7,4. Para a realização da contagem do número de (UFC) unidades formadoras de colônias foi inoculado em cada meio $100 \mu \mathrm{L}$ de suspensão preparada a partir do tubo 0,5 da escala de Mc Farland, diluída a 1: 1000.

TABELA 10 - NÚMERO DE UNIDADES FORMADORAS DE COLÔNIAS
\begin{tabular}{lcc} 
(UFC) DOS ENTEROPATÓGENOS EM MacConkey EM pH & $\mathbf{5 , 0}$ e pH 7,4 \\
\hline ENTEROPATÓGENOS & MC pH = 5,0 & MCpH = 7,4 \\
\hline Salmonella enterica & 710 ufc & 715 ufc \\
Shigella sonnei & 700 ufc & 718 ufc \\
Escherichiacoli EPEC & 715 ufc & 732 ufc
\end{tabular}

ufc = Unidade formadora de colônia

Com estes resultados podemos verificar mais uma vez que o $\mathrm{pH}$ ácido do meio não influi significativamente no crescimento dos enteropatógenos em estudo, assegurando nossos resultados da ação inibitória da quitosana frente aos mesmos.

\subsubsection{Observação da reação de precipitação da quitosana em pH} superior a 6,5 .

As soluções de quitosana em faixas de $\mathrm{pH}$ superiores a 6,5 sofrem reação de precipitação e passam a se apresentar na forma de flocos gelatinosos (CHEN,R.H., 1996). Considerando esta característica foi realizado o teste para avaliar a reação das soluções de quitosana utilizadas, variando o pH do meio 
entre 4,0 e 8,0, tornando assim a reação bem evidente, como indicado nas figuras $33 \mathrm{~A}$ e $33 \mathrm{~B}$.

A importância deste teste é diretamente relacionada à leitura do teste para avaliar a Concentração Inibitória Mínima (CIM), uma vez que a reação de precipitação levaria à margem de erro quanto à interpretação da ação inibitória da quitosana sobre os enteropatógenos aqui estudados. Associado a isso tem reportado na literatura que a ação inibitória da quitosana sobre os microrganismos gram positivos e gram negativos é mais eficaz quanto mais ácido for o meio utilizado, sendo $\mathrm{pH}=5,0$ o mais indicado (QI, L. et al, 2004; TSAI, G.J. \& SU, W.H., 1999, NO, H.K. et al., 2002).

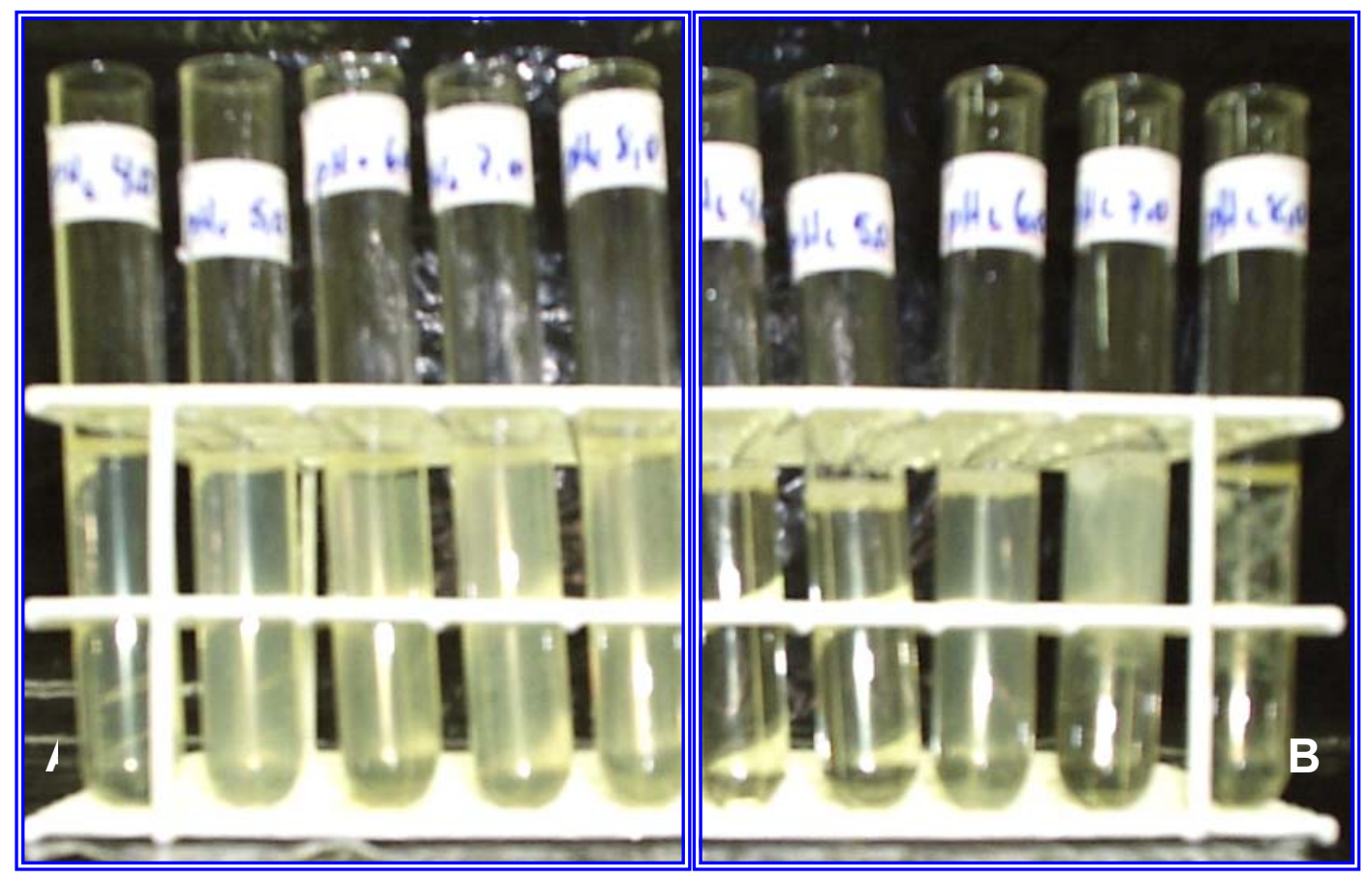

Figura $33 \mathrm{~A}$ - série de quitosana derivada de camarão em meio $\mathrm{MHB}$ em pH: 4,0; 5,0; 6,$0 ; 7,0$ e 8,0 .

Figura $33 \mathrm{~B}$ - série de quitosana derivada de lula em meio MHB em pH: 4,0; 5,0; 6,0; 7,0 e 8,0 .

As figuras 34A e 34B apresentam as duas séries de quitosana em meio MHB após 24 horas de incubação a $37^{\circ} \mathrm{C}$ para confirmar através da 
visualização direta a reação de precipitação em pH acima de 6,5. (MUZZARELLI, 1973).

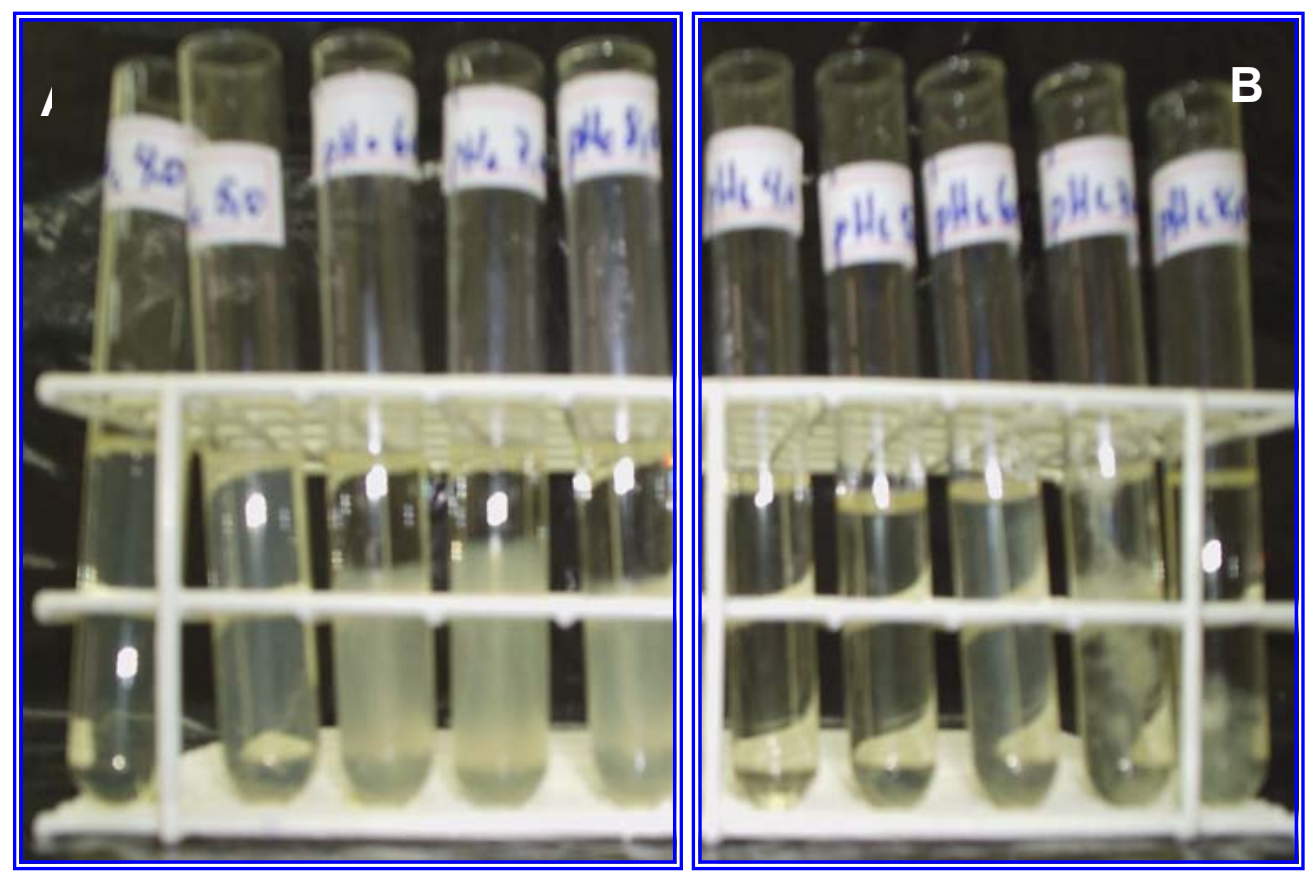

Figura 34A - série de quitosana derivada de camarão em meio MHB nas faixas de $\mathrm{pH}: 4,0 ; 5,0 ; 6,0 ; 7,0$ e 8,0 , após $24 \mathrm{~h} / 37^{\circ} \mathrm{C}$ de incubação

$34 \mathrm{~B}$ - série de quitosana derivada de lula em meio MHB nas faixas de $\mathrm{pH}: 4,0 ; 5,0 ; 6,0 ; 7,0$ e 8,0 , após $24 \mathrm{~h} / 37^{\circ} \mathrm{C}$ de incubação.

4.3.4 AVALIAÇÃO DA CONCENTRAÇÃo INIBITÓRIA MÍNIMA (CIM) DE QUITOSANA DERIVAdA DE CAMARÃo E LULA PELO MÉTOdO QUANTITATIVO PARA OS ENTEROPATÓGENOS EM ESTUDO.

\subsubsection{CONCENTRAÇÃO INIBITÓRIA MÍNIMA PARA SOLUÇÃO DE QUITOSANA DERIVADA DE CAMARÃO PARA S. enterica.}

A figura 35 mostra a CIM da solução de quitosana derivada de camarão para Salmonella enterica no tubo de número 4 , o qual apresenta 
concentração de aproximadamente $0,03 \%$ e diluição de 1:8 da solução de quitosana utilizada.

Os controles negativos da solução de quitosana derivada de camarão, assim como o do meio de cultura MHB, utilizados na prova se mostram límpidos, aparentemente estéreis.

O tubo controle positivo da S.enterica, desprovido de quitosana se mostra bastante turvo pelo crescimento bacteriano.

Os tubos de número cinco a dez da série se mostram com elevado grau de turvação pelo crescimento bacteriano indiferente à presença da quitosana.

\section{CIM de Quitosana derivada de camarão para Salmonella enterica}

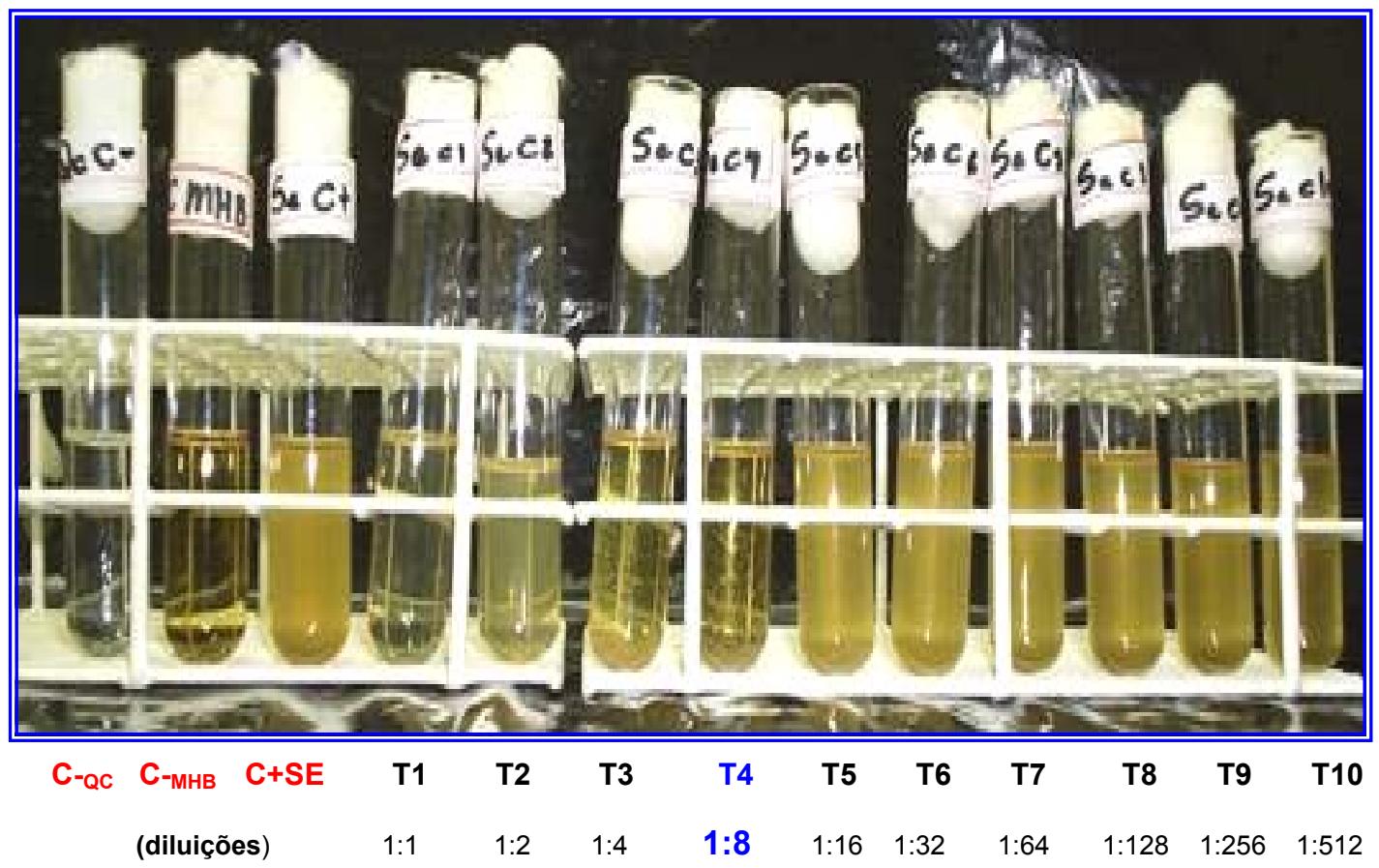

$\mathrm{C}-\mathrm{QC}=$ Controle negativo da solução de quitosana derivada de camarão

$\mathrm{C}_{-\mathrm{MHB}}=$ Controle negativo do caldo Müeller Hinton

$\mathrm{C}+{ }_{\mathrm{SE}}=$ Controle positivo do crescimento de Salmonella enterica.

Figura 35 - CIM de Quitosana derivada de camarão para Salmonella enterica

\subsubsection{CONCENTRAÇÃO INIBITÓRIA MÍNIMA PARA SOLUÇÃO DE QUITOSANA DERIVADA DE LULA PARA S. enterica.}


A figura 36 mostra a CIM da solução de quitosana derivada de lula para Salmonella enterica no tubo de número 3, o qual apresenta concentração aproximada de $0,06 \%$, diluição de 1:4 da solução utilizada.

Os controles negativos da solução de quitosana derivada de camarão, assim como o do meio de cultura MHB, utilizados na prova mostram se límpidos, aparentemente estéreis.

O tubo controle positivo da S.enterica, desprovido de quitosana se mostra bastante turvo pelo crescimento bacteriano.

Os tubos de número quatro a dez da série se mostram com elevado grau de turvação pelo crescimento bacteriano indiferente à presença da quitosana.

\section{CIM de Quitosana derivada de lula para Salmonella enterica}

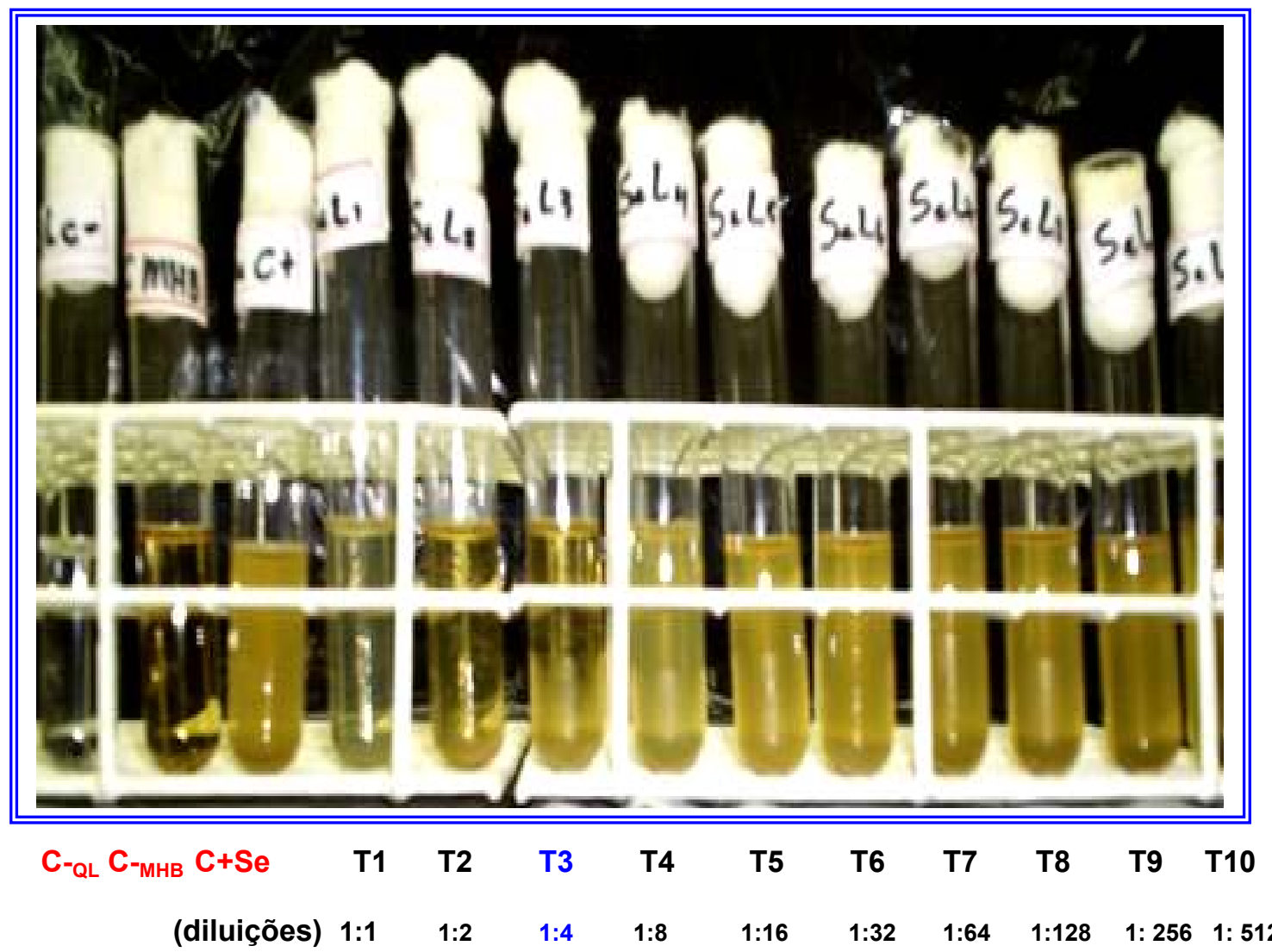

$\mathrm{C}-{ }_{\mathrm{QL}}=$ Controle negativo da solução de quitosana derivada de lula

$\mathrm{C}-{ }_{\mathrm{MHB}}=$ Controle negativo do caldo Müeller Hinton

$\mathrm{C}+{ }_{\mathrm{SE}}=$ Controle positivo do crescimento de Salmonella enterica

Figura 36 - CIM da solução de quitosana derivada de lula para S. enterica 


\subsubsection{CONCENTRAÇÃO INIBITÓRIA MÍNIMA PARA SOLUÇÃO DE QUITOSANA DERIVADA DE CAMARÃO PARA S.sonnei}

A figura 37 mostra a CIM da solução de quitosana derivada de camarão no tubo de número 9 , o qual apresenta concentração de aproximadamente $0,0001 \%$, e diluição de 1:256 da solução utilizada.

Os controles negativos da solução de quitosana derivada de camarão, assim como o do meio de cultura MHB, utilizados na prova se mostram límpidos, aparentemente estéreis.

O tubo controle positivo da S. sonnei, desprovido de quitosana se mostra bastante turvo pelo crescimento bacteriano.

O tubo de número dez da série se mostra com elevado grau de turvação pelo crescimento bacteriano indiferente à presença da quitosana.

\section{CIM da solução de quitosana derivada de camarão para Shigella sonnei}

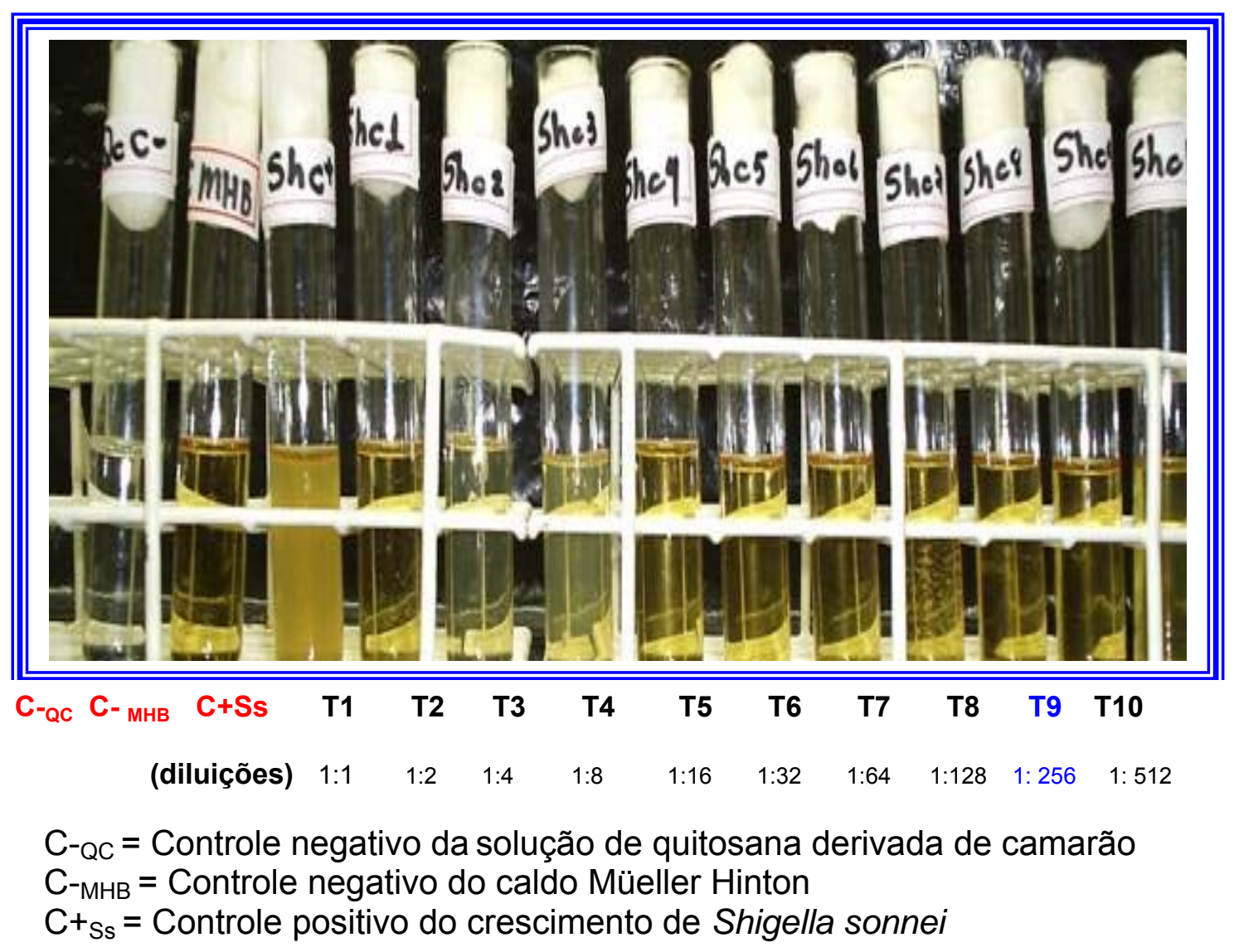

Figura 37 - CIM de Quitosana derivada de camarão para Shigella sonnei 


\subsubsection{CONCENTRAÇAÕINIBITÓRIA MÍNIMA PARA SOLUÇÃO DE QUITOSANA DERIVADA DE LULA PARA S.sonnei.}

A figura 38 mostra a CIM da solução de quitosana derivada de lula para Shigella sonnei no tubo de número 9, o qual apresenta concentração de aproximadamente $0,0001 \%$ e diluição de 1:264 da solução utilizada.

Os controles negativos da solução de quitosana derivada de lula, assim como o do meio de cultura MHB, utilizados na prova se mostram límpidos, aparentemente estéreis.

O tubo controle positivo da S. sonnei, desprovido de quitosana se mostra bastante turvo pelo crescimento bacteriano.

O tubo de número dez da série se mostra com elevado grau de turvação pelo crescimento bacteriano indiferente à presença da quitosana.

CIM da solução de quitosana derivada de lula para Shigella sonnei

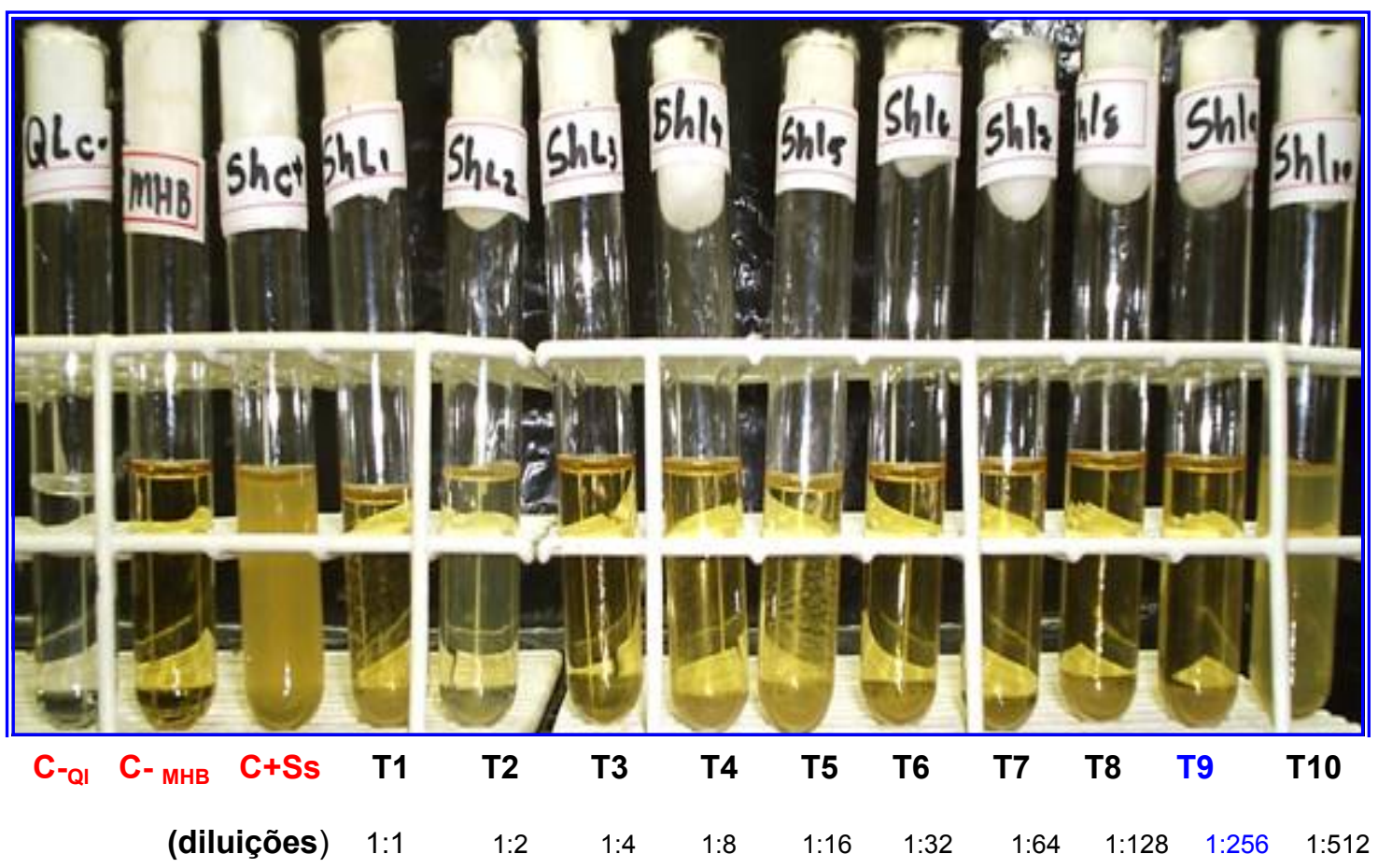

$\mathrm{C}-_{\mathrm{QL}}=$ Controle negativo da solução de quitosana derivada lula

$\mathrm{C}_{-\mathrm{MHB}}=$ Controle negativo do caldo Müeller Hinton

$\mathrm{C}+\mathrm{ss}_{\mathrm{s}}=$ Controle positivo do crescimento de Shigella sonnei. 


\subsubsection{CONCENTRAÇÃO INIBITÓRIA MÍNIMA PARA SOLUÇÃO DE QUITOSANA DERIVADA DE CAMARÃO PARA E. coli EPEC.}

A figura 39 mostra a CIM da solução de quitosana derivada de camarão para Escherichia coli enteropatogênica no tubo de número 4, o qual apresenta concentração de aproximadamente $0,03 \%$ e diluição de $1: 8$ da solução utilizada.

Os controles negativos da solução de quitosana derivada de camarão, assim como o do meio de cultura MHB, utilizados na prova se mostram límpidos, aparentemente estéreis.

O tubo controle positivo da Escherichia coli EPEC, desprovido de quitosana se mostra bastante turvo pelo crescimento bacteriano.

Os tubos de número 5 a dez da série se mostram com elevado grau de turvação pelo crescimento bacteriano indiferente à presença da quitosana.

\section{CIM da solução de quitosana derivada de camarão para E. coli EPEC}

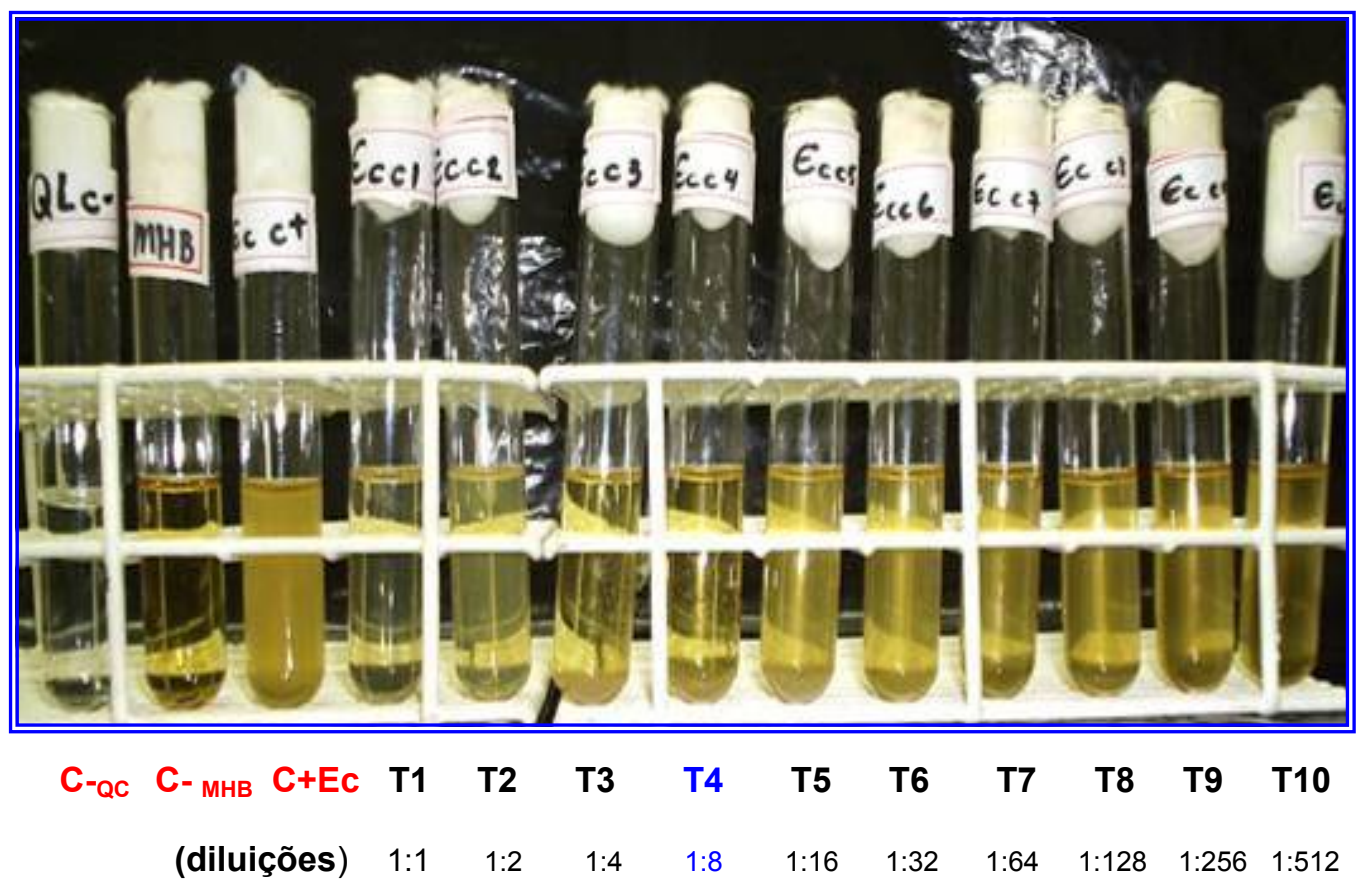

$\mathrm{C}$-QC $=$ Controle negativo da solução de quitosana derivada de camarão C-мнв $=$ Controle negativo do caldo Müeller Hinton 


\subsubsection{CONCENTRAÇÃO INIBITÓRIA MÍNIMA PARA SOLUÇÃO DE QUITOSANA DERIVADA DE LULA PARA E. coli EPEC.}

CIM da solução de quitosana derivada de lula para E. coli EPEC.

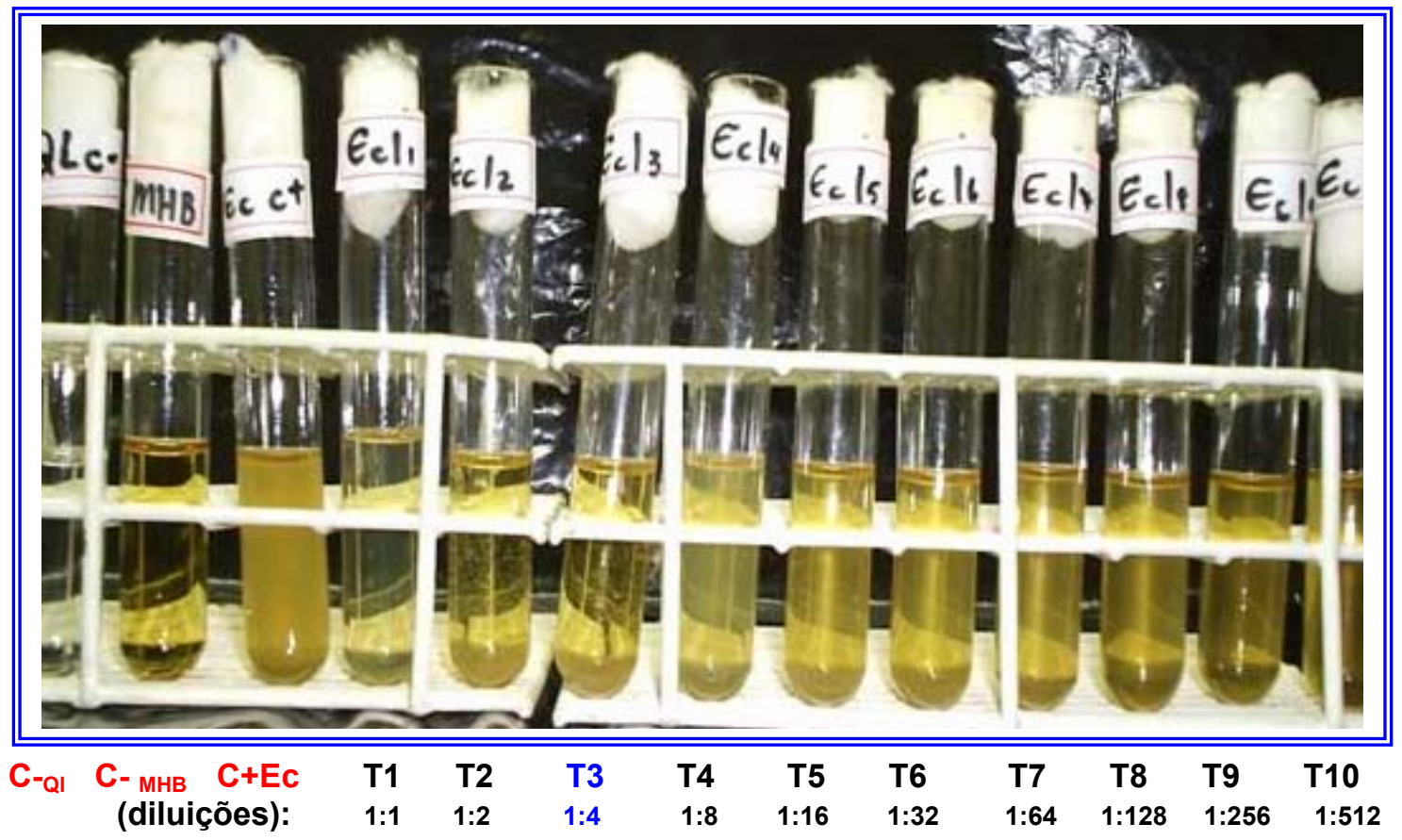

$\mathrm{C}$-QL $=$ Controle negativo da solução de quitosana derivada de lula $\mathrm{C}_{-\mathrm{MHB}}=$ Controle negativo do caldo Müeller Hinton

$\mathrm{C}+{ }_{\mathrm{Ec}}=$ Controle positivo do crescimento de E. coli EPEC

Figura 40 - CIM de Quitosana derivada de lula para Escherichia coli EPEC

A figura 40 mostra a CIM da solução de quitosana derivada de lula para Escherichia coli enteropatogênica no tubo de número 3, o qual apresenta concentração de aproximadamente de $0,06 \%$ e diluição de $1: 4$ da solução utilizada. Os controles negativos da solução de quitosana derivada de lula, assim como o do meio de cultura MHB, utilizados na prova se mostram límpidos, aparentemente estéreis. O tubo controle positivo da Escherichia coli EPEC, 
desprovido de quitosana se mostra bastante turvo pelo crescimento bacteriano. Os tubos de número 4 a dez da série se mostram com elevado grau de turvação pelo crescimento bacteriano indiferente à presença da quitosana. 


\subsubsection{AVALIAÇÃO DA AÇÃO BACTERICIDA ATRAVÉS DO PLAQUEAMENTO OU SUBCULTURA DOS TUBOS QUE NÃO APRESENTARAM TURVAÇÃO.}

\subsubsection{CONCENTRAÇÃO BACTERICIDA MÍNIMA DAS SOLUÇÕES DE QUITOSANA DERIVADAS DE CAMARÃO E DERIVADA DE LULA PARA S. enterica.}

A CIM é dada pela menor concentração capaz de inibir o crescimento bacteriano, enquanto que a Concentração Bactericida Mínima é dada pela menor concentração capaz de matar o microrganismo.

A figura 41 apresenta a CBM da quitosana derivada de camarão e de lula para a Salmonella enterica, obtida através do plaqueamento dos tubos que não apresentaram turvação. A CBM para S. enterica é de $0,1 \%$, onde a diluição é de 1:2, seja pela quitosana derivada de camarão ou derivada de lula.

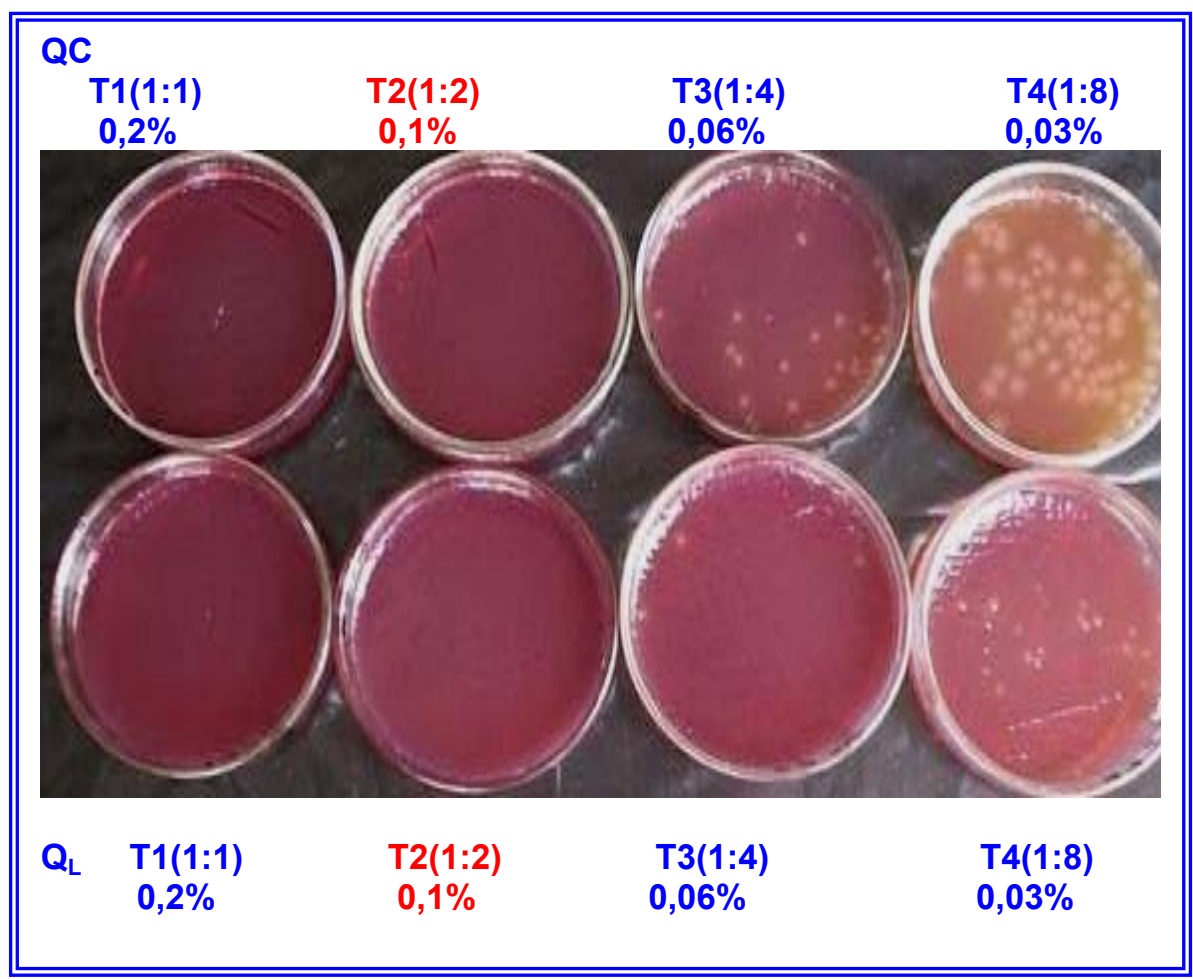

Figura 41 - CBM das soluções de quitosana derivadas de camarão e lula para Salmonella enterica. 


\subsubsection{CONCENTRAÇÃO BACTERICIDA MÍNIMA DA SOLUÇÃO DE QUITOSANA DERIVADA DE CAMARÃO PARA S.sonnei}

A figura 42 apresenta a CBM da quitosana derivada de camarão para a Shigella sonnei, obtida através do plaqueamento dos tubos que não apresentaram turvação. A CBM para S. sonnei é de 1:32 .

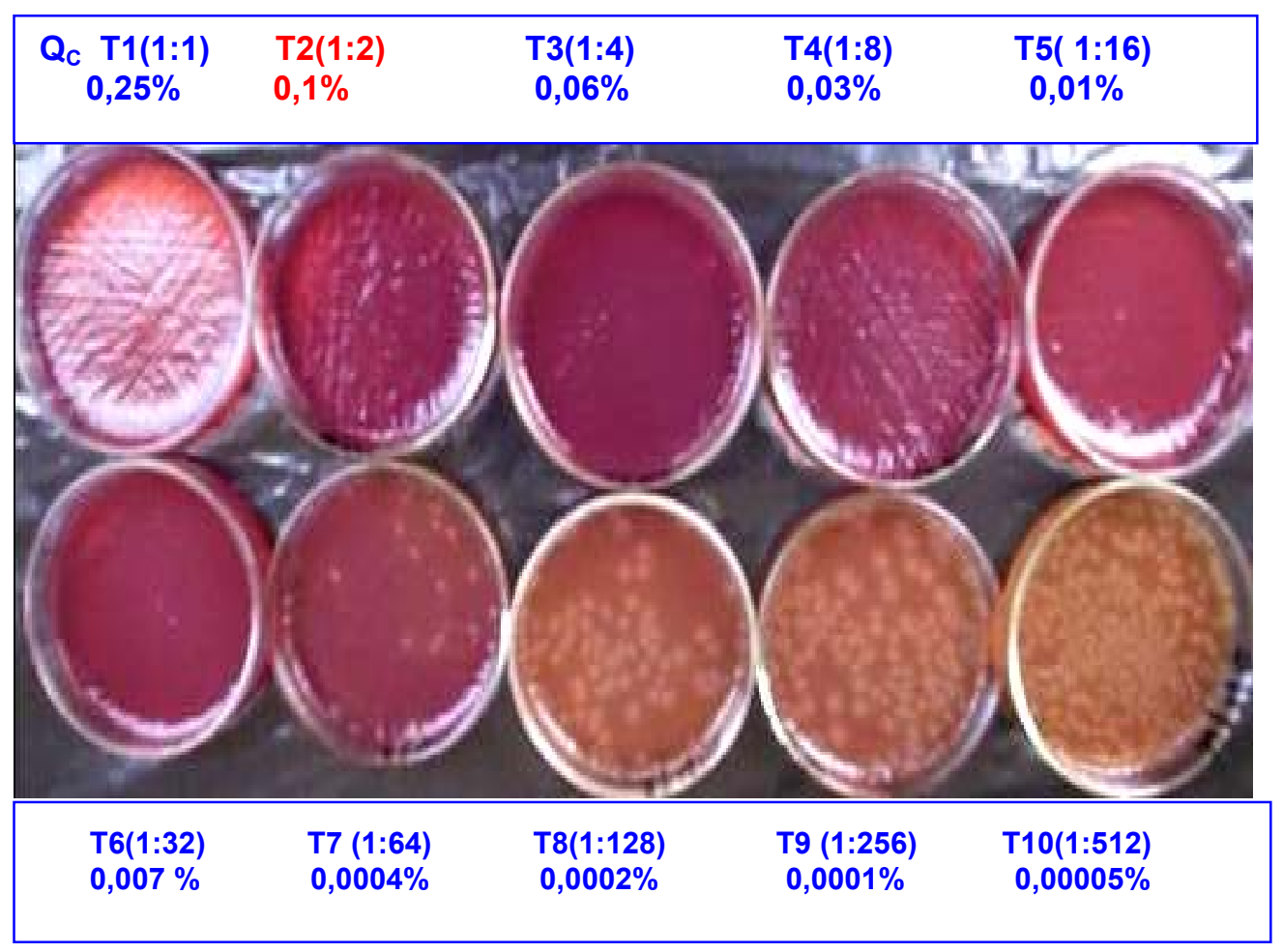

Figura 42- CBM de quitosana derivada de camarão para Shigella sonnei

\subsubsection{CONCENTRAÇÃO BACTERICIDA MÍNIMA DA SOLUÇÃO DE QUITOSANA DERIVADA DE LULA PARA S. sonnei.}

A figura 43 apresenta a CBM da quitosana derivada de lula para a Shigella sonnei, obtida através do plaqueamento dos tubos que não 
apresentaram turvação. A CBM para S. sonnei é de 1:32, ou seja, o mesmo valor obtido da solução de quitosana derivada de camarão.

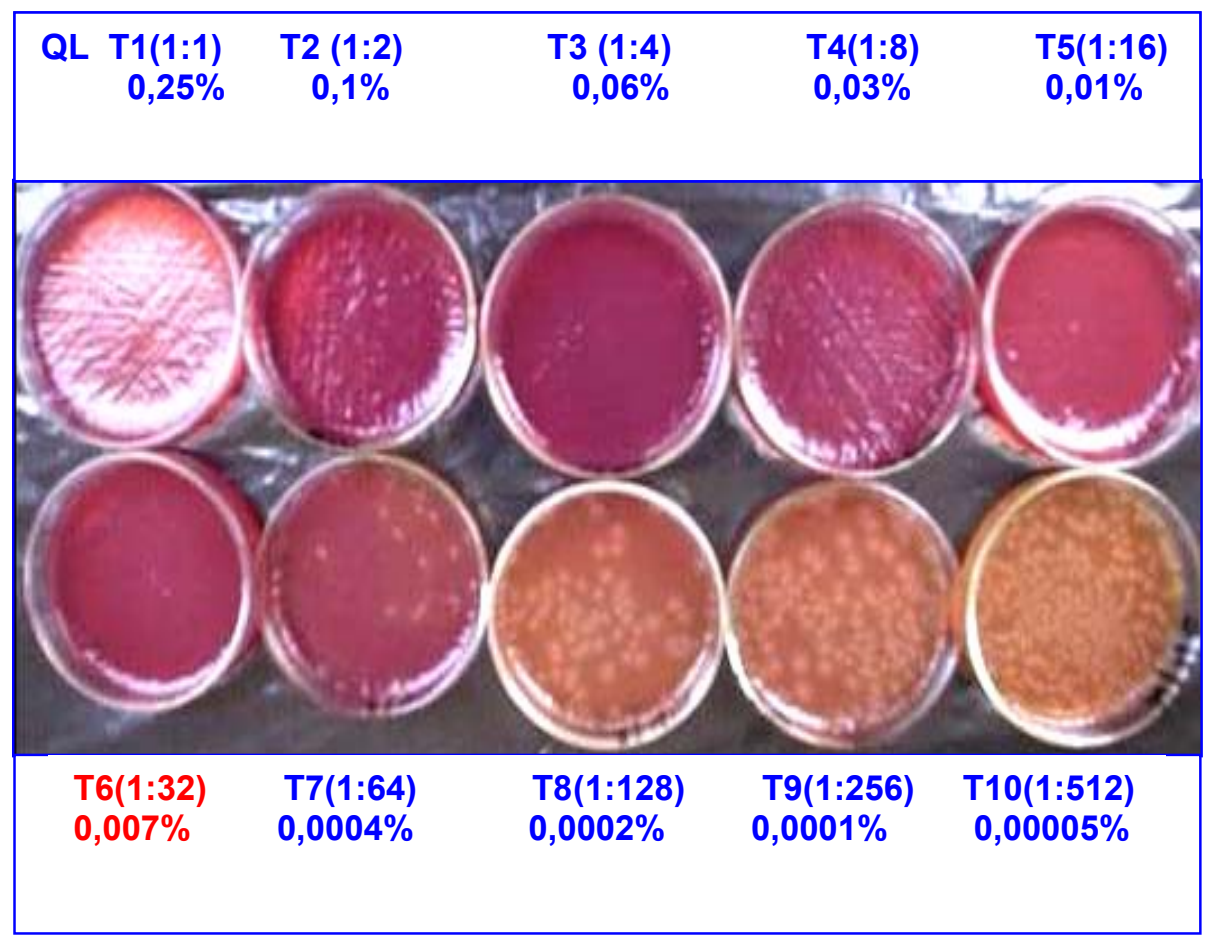

Figura 43 - CBM de quitosana derivada de lula para Shigella sonnei.

\subsubsection{CONCENTRAÇÃO BACTERICIDA MÍNIMA DAS SOLUÇÕES DE QUITOSANA DERIVADAS DE CAMARÃO E DERIVADA DE LULA PARA E.coli EPEC.}

A figura 44 apresenta a CBM da quitosana derivada de camarão e de lula para a E.coli EPEC, obtida através do plaqueamento dos tubos que não apresentaram turvação. A CBM para E.coli EPEC é de 1:2, seja pela quitosana derivada de camarão ou derivada de lula. 


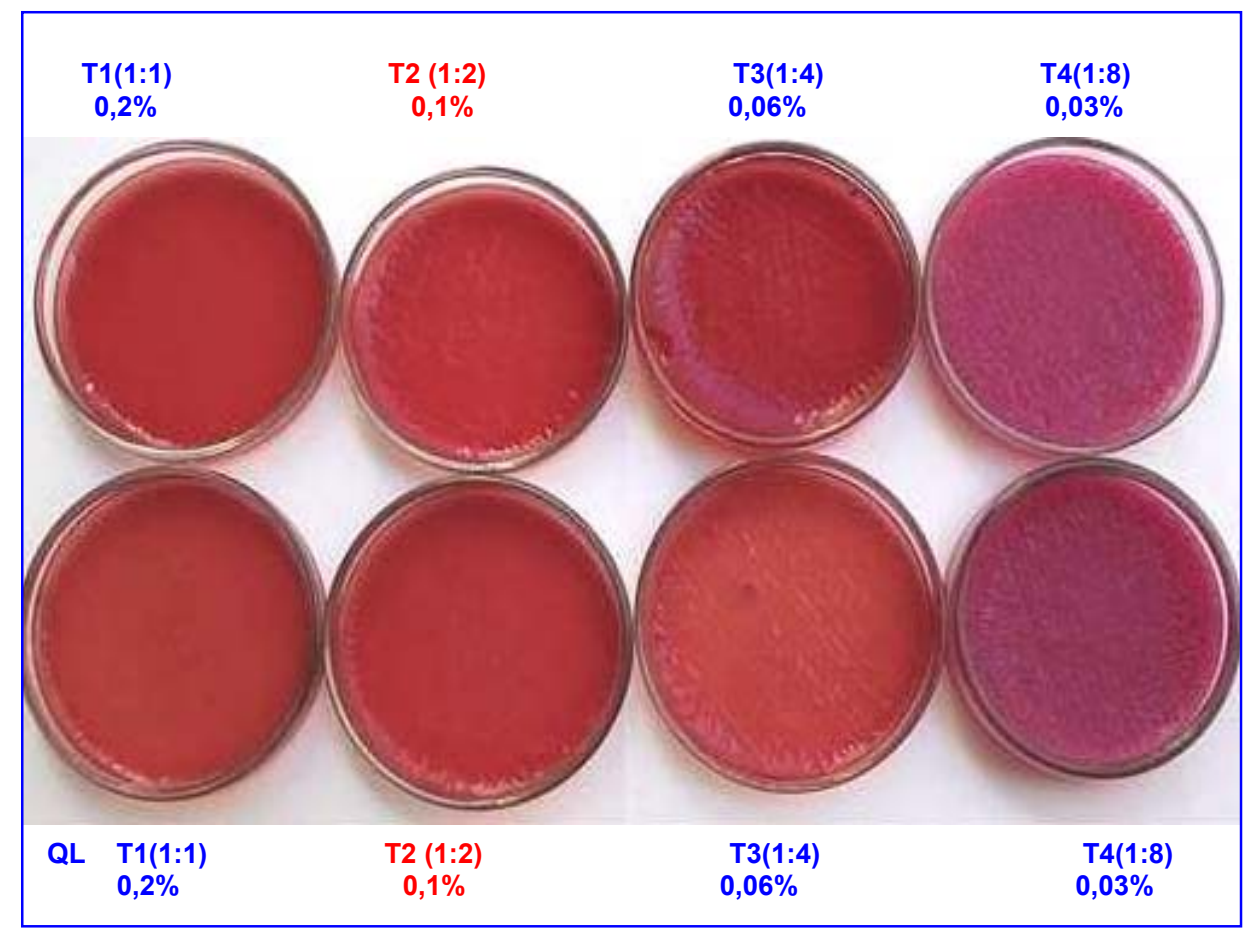

Figura 44 - CBM de quitosana derivada de camarão e de lula para E. coli EPEC 
Tabela 11 - CONCENTRAÇÃO INIBITÓRIA MÍNIMA E CONCENTRAÇÃO BACTERICIDA MÍNIMA DAS SOLUÇÕES DE QUITOSANA DERIVADAS DE CAMARÃO E DERIVADA DE LULA PARA OS ENTEROPATÓGENOS

\begin{tabular}{|c|c|c|c|c|c|c|c|c|c|c|c|c|c|c|}
\hline \multirow[b]{3}{*}{$\begin{array}{l}N^{\circ} \text { do } \\
\text { tubol } \\
\text { placa }\end{array}$} & \multirow[b]{3}{*}{$\begin{array}{c}\text { Diluição da } \\
\text { solução }\end{array}$} & \multirow[b]{3}{*}{$\begin{array}{c}\text { Concentração } \\
\text { da solução de } \\
\text { quitosana }\end{array}$} & \multicolumn{4}{|c|}{ Salmonella enterica } & \multicolumn{4}{|c|}{ Shigella sonnei } & \multicolumn{4}{|c|}{ E.coli EPEC } \\
\hline & & & \multicolumn{2}{|c|}{ CIM } & \multicolumn{2}{|c|}{ CBM } & \multicolumn{2}{|c|}{ CIM } & \multicolumn{2}{|c|}{ CBM } & \multicolumn{2}{|c|}{ CIM } & \multicolumn{2}{|c|}{ CBM } \\
\hline & & & QL & QL & QC & QL & QC & QL & QC & QL & QC & QL & QC & QL \\
\hline $\mathrm{T1}$ & $1: 1$ & $0,25 \%$ & - & - & & & - & - & & & - & - & & \\
\hline T2 & $1: 2$ & $0,125 \%$ & - & - & & & - & - & & & - & - & & \\
\hline T3 & $1: 4$ & $0,0625 \%$ & - & $=$ & + & + & - & - & & & - & - & + & + \\
\hline T4 & $1: 8$ & $0,0312 \%$ & - & + & + & + & - & - & & & - & + & + & + \\
\hline $\mathrm{T5}$ & $1: 16$ & $0,015 \%$ & + & + & + & + & - & - & & & + & + & + & + \\
\hline T6 & $1: 32$ & $0,0078 \%$ & + & + & + & + & - & - & & & + & + & + & + \\
\hline T7 & $1: 64$ & $0,0004 \%$ & + & + & + & + & - & - & + & + & + & + & + & + \\
\hline T8 & $1: 128$ & $0,0002 \%$ & + & + & + & + & + & + & + & + & + & + & + & + \\
\hline T9 & $1: 256$ & $0,0001 \%$ & + & + & + & + & + & + & + & + & + & + & + & + \\
\hline 10 & 1:512 & $0,00005 \%$ & + & + & + & + & + & + & + & + & + & + & + & + \\
\hline
\end{tabular}

CIM = Concentração Inibitória Mínima.

$\mathrm{CBM}=$ Concentração Bactericida Mínima

$Q C=$ solução de quitosana derivada de camarão.

$\mathrm{QL}=$ solução de quitosana derivada de lula.
$(-)$ = ausência de crescimento.

$(+)=$ presença de crescimento.

= ausência de crescimento frente à solução de quitosana derivada de lula

= ausência de crescimento frente à solução de quitosana derivada de camarão. 
Concentração Inibitória Mínima (CIM) e Concentração Bactericida Mínima (CBM) das Soluções de Quitosana Derivadas de Lula e Camarão para os Enteropatógenos

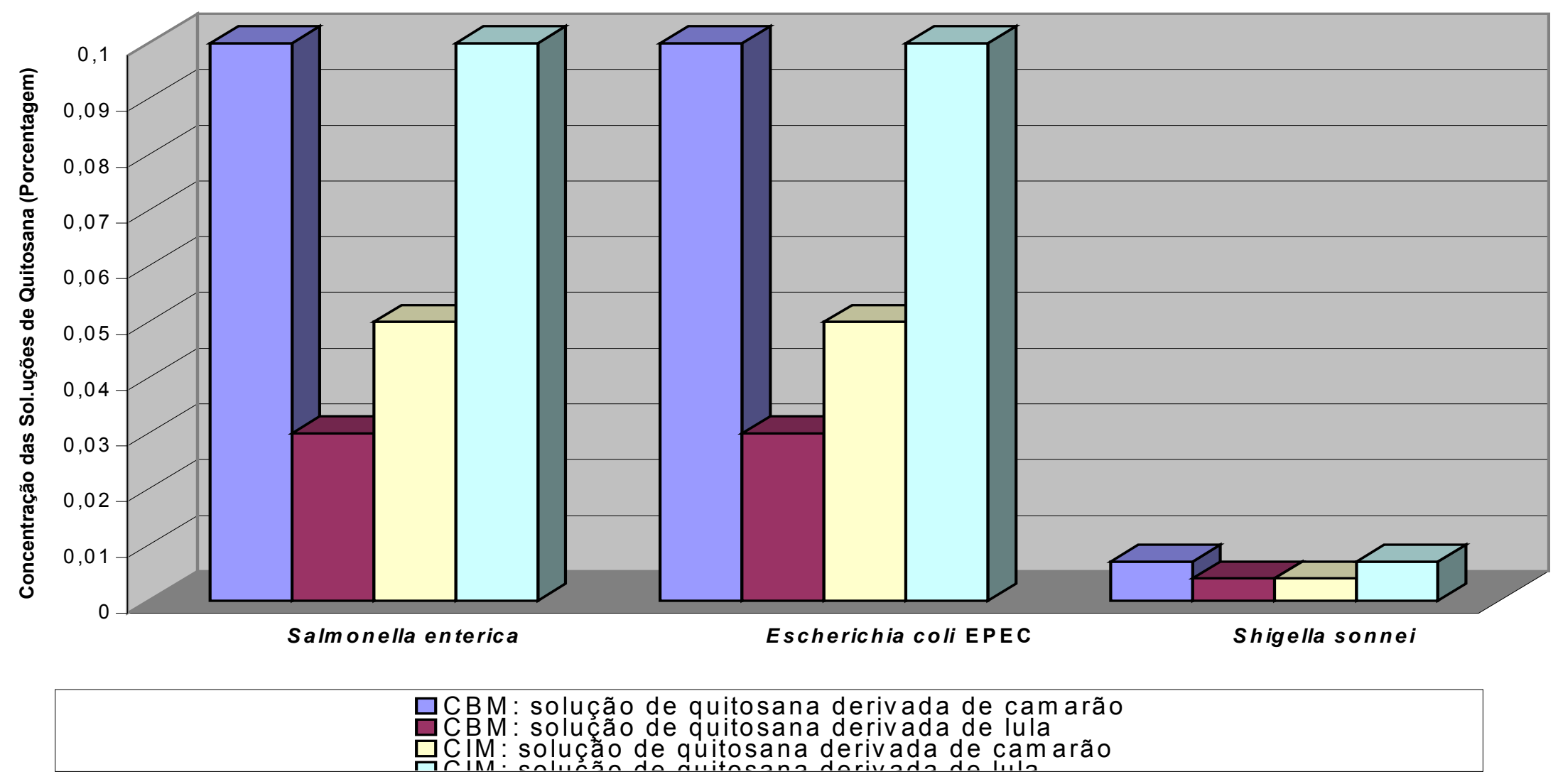

Figura 45 - Gráfico das CIM e CBM das soluções de quitosana para os enteropatógenos 
A atividade antimicrobiana da quitosana sofre influência de vários fatores, como já citado anteriormente. As soluções de quitosana aqui estudadas apresentam a concentração de 0,5\% em solução de ácido acético a $1 \%$ e pH 5,0, mas diferem quanto ao grau de desacetilação e o peso molecular. Apesar disso, não houve pelos enteropatógenos Salmonella enterica e E. coli EPEC diferenças quanto à ação inibitória, seja pela quitosana derivada de camarão ou de lula. A maior diferença observada foi apresentada pelo enteropatógeno Shigella sonnei frente às duas soluções testadas, como indicados na tabela 11 e no gráfico (figura 45).

WANG, G. 1992 demonstrou que para obter ação bactericida da quitosana sobre a $E$. coli foi necessário utilizar solução de concentrações de 0,5 a 1\% em 48 horas de incubação e para obter o mesmo efeito em 24 horas foi preciso utilizar concentrações de quitosana superiores a $1 \%$.

DARMADJI, P. \& IZUMIMOTO, M. 1994 demonstraram que foi preciso usar soluções de quitosana de concentrações maiores que 0,1\% para causar inibição do crescimento da E. coli enquanto que SIMPSON, et al. 1997 demonstraram que para obter inibição do crescimento da $E$. coli foi necessário utilizar solução de quitosana na concentração de 0,0075\%. As soluções de quitosana por eles utilizadas apresentavam $\mathrm{pH}$ abaixo de 5,0 e grau de desacetilação de aproximadamente de 90\%.

Neste estudo verificamos que a Salmonella enterica e a E. coli apresentaram os mesmos valores para a CIM frente à solução de quitosana derivada de camarão (0,03\%, figuras 35 e 39), e frente à solução derivada de lula $(0,06 \%$, figuras 36 e 40$)$, e o mesmo valor para CBM frente às soluções derivadas de camarão e de lula $(0,1 \%$, figuras 41 e 44$)$, portanto valores menores em relação aos reportados na literatura.

Verificamos também através deste estudo que a Shigella sonnei apresentou valores significativamente melhores que os dois enteropatógenos acima citados. Apresentando o mesmo valor da CIM frente às duas soluções de quitosana derivadas de camarão e de lula (0,0004\%, figuras 37 e 38). A CBM foi a mesma frente às duas soluções de quitosana derivadas de camarão e de lula $(0,007 \%$, figuras 42 e 43$)$ também foi expressivamente inferior quando comparada a dos outros dois enteropatógenos. 
TSAI, G.J. et al. 2002 demonstraram que soluções de quitina e quitosana de alto peso molecular e elevado grau de desacetilação para exercer ação letal sobre vários microrganismos testados, entre eles E. coli e Shigella dysenteriae foi necessário concentrações de 50 a 500 ppm. Não foi encontrado na literatura nenhum dado reportado sobre a ação inibitória da quitosana sobre a espécie de Shigella (S. sonnei) presente neste estudo, não havendo portanto dados para comparação da espécie aqui estudada.

Com os resultados obtidos e apresentados neste trabalho, bem como os já reportados na literatura podemos sugerir que a quitosana, com maiores estudos, possa ser explorada nas suas mais diferentes formas de aplicação como medida terapêutica e ou profilática (em zonas endêmicas) frente aos enteropatógenos aqui estudados. 


\section{CONCLUSÕES}

1. O crescimento dos enteropatógenos se apresentou estável em pH 5,0 e 7,4.

2. A S. enterica e a E. coli EPEC apresentaram a mesma CIM frente à solução de quitosana derivada de camarão e também frente à solução de quitosana derivada de lula. Contudo, a CIM obtida pela S.enterica e pela E.coli EPEC frente à solução de quitosana derivada de camarão foi menor que a CIM obtida pelos mesmos frente à solução de quitosana derivada de lula.

3. A Shigella sonnei apresentou a mesma CIM frente às soluções de quitosana derivada de camarão e de lula, e esta foi sensivelmente inferior àquelas obtidas pelos outros enteropatógenos aqui estudados.

4. A S. enterica e a E. coli EPEC apresentaram a mesma CBM frente às soluções de quitosana derivadas de camarão e de lula.

5. A Shigella sonnei apresentou menor CBM frente à solução de quitosana derivada de camarão do que a CBM frente à solução de quitosana derivada de lula

6. As CBM apresentadas pela Shigella sonnei frente às duas soluções de quitosana são expressivamente inferiores às CBM obtidas pelos outros enteropatógenos aqui estudados.

7. Os resultados obtidos neste estudo confirmam a excelente ação inibitória da quitosana sobre os enteropatógenos, além de apresentar dados sobre a Shigella sonnei, até então não reportados na literatura. 


\section{REFERÊNCIAS BIBLIOGRÁFICAS}

BARON, E.J. et al. (1990). Diagnostic microbiology. $8^{\text {th }}$ ed. St.Louis: CV Mosby.

BENENSON, A.S. (Ed.). (1995). Control of communicable dieases manual. $16^{\text {th }}$ ed. Washington: America Health Public Association. p.421- 425.

BERN, C. et al. (1992). The magnitude of the global problem of diarrhoeal disease: a ten-year update. Bulletin of the World Health Organization, Genebra, v.70, n.6, p.705-714.

BIER, O. (1990). Bacteriologia e imunologia. 26 ${ }^{\text {th }}$ ed. São Paulo: Melhoramentos.

BOYD, E.F. et al. (1996). Molecular genetic relaeitionsship of the salmonellae. Applied Environment Microbiology, Baltimore, v.62, n.3, p.804-808, Mar.

BYTZER, P.et al. (1990). Etiology, medical history and faecal weight in adulto patients referred for diarrhoea: a prospective survey. Scandinavian Journal of Gastroenterology, Oslo, v.25, n.6, p.572, June.

CAMPANA- FILHO, S.P.; FROLLINI, E.; DESBRIERES, J. (2000). Chitin, chitosan and derivatives. In: FROLLINI, E. et a. (Ed.). Natural polymers and agrofibers based composites. São Carlos: IQSC/USP/UNESP; EMBRAPA Instrumentação Agropecuária. p. 41-71. 2000. 
CELLI, J.; DENG, W.; FINLAY, B.B. (2000). Enteropathogenic E.coli (EPEC) attchament to epithelial cells: explotting the host cell cytoeskeleton from the outside. Cellular Microbiology, Oxford, v.2, n.1, p.1-9, Feb.

CHANG, D.S. et al. (1989). Development of food preservation with the waste of crab processing. Bulletin Korean Fishieries Society, Korea, v.22, p.70-78.

CHEN, R.H.; HWA, H.D. (1996). Effect of molecular weight of chitosan with the same degree of deacetylation on the thermal, mechanical, and permeability properties of the prepared membrane. Carbohydrate Polymers, Barking, v.29, n.4, p.353-358, Apr.

CHO, H.R. et al. (1998). Utilization of chitosan hydrolisate as a natural food preservative for fish meat past products. Journal Food Science Technology, Korean, v.30, n.4, p.817-822.

CHOI, B.K. et al. (2001). In vitro antimicrobial activity of a chitooligosaccharide mixture against actinobacillus actinomycetemcomitans and Streptococcuss mutans. International Journal of Antimicrobial Agents, Amsterdam, v.18, n.6, p.553-557, Dec.

CHUNG, Y.C. et al. (2004). Relationship between antibacterial activity of chitosan and surface characteristics of cell wall. Acta Pharmacologica Sinica, Malden, v.25, n.7, p.932-936.

CRAVEIRO, A.A. et al. (1999). Quitosana - a fibra do futuro. Fortaleza: PADETEC/UFC.

DARMADJI, P.; IZUMIMOTO, M. (1994). Effect of chitosan in meat preservation. Meat Science, Barking, v.38, n.2, p.243-254.

DOMARD, A. (1987). Determination of $\mathrm{N}$-acetyl content in chitosan samples by c.d.measurements. International Journal of Biological Macromolecules, Oxford, v.9, n.6, p.333-336, Dec. 
DOMARD, A.; RINALDO, M. (1983). Preparation and characterization of fully deacetylated chitosan. International Journal of Biological Macromolecules, oxford, v.5, n.1, p.49-52, Feb.

GUERRANT, R.L. et al. (1990). Diarrhea in developed and developing countries: magnitude, special settings, and etiologies. Reviews of Infectious Diseases, Chicago, v.12, p.S41-S50, Jan./Feb. Supl.1

GOLDMAN, A.S. (1977). Human milk, leukocytes and immunity. Journal of Pediatrics, St.Louis, v.90, n 1, p.167-168.

GOMES, T.A.T. et al (1991). Enterophathogens associated with acute diarrhoeal disease in urban infantis in São Paulo, Brazil. Journal of Infectious Diseases, Chicago, v.164, n.2, p.331-337, Aug.

. (1996). EPEC infections in São Paulo. Revista de Microbiologia, São Paulo, v.27, p.25-33, Supl.1.

GUTH, B.E.C. (2000). Enterotoxigenic Escherichia coli - an evernew. Memórias do Instituto Oswaldo Cruz, Rio de Janeiro, V.95, p.95- 97, Supl. 1

HELANDER, I.M. et al. (2001). Chitosan disrupts the barrier properties oh the outher membrane oh gram negative bacteria. International Journal of Food Microbiology, Amsterdam, v.71, n.2/3, p.235-244, Dec.

HIRANO, S. et al (1988). Biocompatibility of chitosan by oral and intravenous administrations. Polymeric Materials Science and Engineering, Washington, v.59,p.897-901.

JEON, Y.J.; PARK, P.J.; KIM, S.K. (2001). Antimicrobial effect of chitooligosaccharides produced by bioreactor. Carbohydrate Polymers, Barking, v.44, n.1, p.71-76, Jan. 
JUMAA, M.; FURKET, F.H.; MÜLLER, B.W. (2002). A new lipid emulsion formulation with high antimicrobial efficacy using chitosan. European Journal of Pharmaceutics, Stuttgart, v.53, n.1, p.115-123, Jan.

JUNG, B.O. et al. (1999). Preparation of amphiphilic chitosan and their antimicrobial activities. Journal of Applied Polymer Science, New York, v.72, n.13, p.1713-1719, June.

JOSUÉ, A. Et al. (2000). Liberação controlada da eosina impregnada em microesferas de copolímero de quitosana e poli (ácido acrílico). Polímeros: Ciência e Tecnologia, São Carlos, v.3, n.10, v.3, p.116-121, jul./set.

KAPER, J.B. (1996). Defining EPEC. Revista de Microbiologia, São Paulo, v.27, p.130-133, Supl.1

KAUFFMANN, F. (1978). Das fundament. Munksgaard: [s.n.].

KENDRA, D.F.; HADWIGER, L.A. (1989). Caracterization oh the smallest chitosan oligomers that is maximally antifungal to fusarium solani and elecits formation in pisum sativum. Experimental Micology, Amsterdam, v.8, n.3, p.276-281, Sept.

KNORR, D. (1984). Use of chitinous polymers in food: a challenge for food research and development. Food Technology, Champaign, v.38, n.1, p.85-97.

KIMURA, I.Y. (2001). Remoção de corantes reativos contendo grupos vinilsulfona e triazina por absorção e coagulação com quitosana. 200p. Tese (Doutorado) - Universidade Federal de Santa Catarina, Florianópolis, 2001.

KOTTOFF, K.L. et al. (2000). Carga mundial de infecciones por Shigella: implications para el desarrollo de vacunas y la aplicación de estrategias del control. Bulletin of World Health Organization, Genebra, n.77, v.8, p.651666. 
KUMAR, M.N.V.R. (2000). A review of chitin and chitosan applications. Reactive \& Functional Polymers, Amsterdam, v.46, n.1, p.1-27, Nov.

KURITA, K. et al. (1993). Squid chitin as a potential alternative chitin sourcedeacetylation behavior and characteristic properties. Journal of Polymer Science: part A - polymer chemistry, New York, v.31, n.2, p.485-491.

LADEFOGED, K.; SCHAFFALITZKY DE MUCKADELL, O.B. (1987). Fecal osmolality and electrolyte concentrations in chronic diarrhea: do the provide diagnostic clues. Scandinavian Journal of Gastroenterology, Oslo, v.22, n.7, p.813-820, Sept.

LEE, K.Y.; HA, W.S.; PARK, W.H (1996). Blood compatibilçity and biodegradability of partially N- acetylated chitosan. Biomaterials, Guildford, v.16, n.16, p.1211-1216.

MADHAVAN, P.; NAIR, K.G. (1974). Utilization of prawn waste- Isolation of chitin and is conversion to chitosan. Fishery Technology, Cochin, v.1, n.11, p.50-53.

MADIGAN, M.T.; MARTINKO, J.M.; PAKER, J. (2004). Microbiologia de Brock. Tradução e revisão técnica de Cyntia Maria Kyaw. 10.ed. São Paulo: Pearson Education do Brasil.

MATHUR, N.K.; NARANG, C.K. (1990). Chitin and chitosan, versatile polysaccharides from marine animals. Journal of Chemical Education, Easton, v.67, n.11, p.939-943.

MÜELLER, J.H.; JANE, H. (1941). Performance Standards for Antimicrobial Susceptibility Testing. Proceedings of the society for Experimental Biology and Medicine, Malden, v.48, p.330-349.

MURRAY, P.R. et al. (1998). Medical microbiology. $3^{\text {th }}$ ed. St.Louis: Mosby. . (Ed.). 2003). Manual of clinical microbiology. $8^{\text {th }}$ ed. Washington: Asm Press. 
MUZZARELLI, R.A.A. (1973). Natural Chelating Polymers. Perganon, Korea.

. (1985). Chitin. In: MARK, H.F. et al. (Ed.). Encyclopedia of polymers

science engineering. $2^{\text {nd }}$ ed. New York: John Wiley. v.3, p.430-441.

. (1996). Chitin and human body. In: DOMARD, A. (Ed.). Advances in

chitin science. Lyon: J.André. v.1, p.448-461.

MUZZARELLI, R.A.A. et al. (1988). Biological activity of chitosan ultrastructural study. Biomaterials, Guildford, v.9, n.3, p.247-252, May.

NATARO, J.P.; STAINER, T.; GUERRANT, R.L. (1998). Enteroaggregative E.coli. Emerging Infectious Diseases, Atlanta, v.4, n.2, p.251- 261, Apr./June.

NO, H.K.; MEYERS, S.P. (1989). Crawfish chitosan as a coagulant in recovery of organic compounds from scafood processing streams. Journal Agricultural and Food of Chemistry, Easton, v.37, n.3, p.580-583.

NO, H.K. et al (2002). Antibacterial activity of chitosans and chitosan oligomers with different molecular weights. International Journal of Food Microbiology, Amsterdam, v.74, n.1/2, p.65-72, Mar.

NORDTVEIT, R.J.; VARUM, K.M.; SMIDSROD, O. (1994). Degradation of fully water soluble partially $\mathrm{N}$-acetylated chitosans with lysosyme. Carbohydrate Polymers, Barking, v.23, n.4, p.253-260.

PARQUE DE DESENVOLVIMENTO TECNOLÓGICO. Universidade Federal do Ceará. (2004). Disponível em:<www.Padetec.ufc.br>. Acesso em: 15 mar. 2004.

PELCZAR JR., M.J. et al. (1997). Microbiologia: conceitos e aplicações. Tradução de Sueli Fumie Yamada; Tânia Ueda Nakamura e Benedito Prado Dias Filho. 2.ed. São Paulo: Makron Books. 
POLYMAR INDÚSTRIA E COMÉRCIO DE IMPORTAÇÕES E EXPORTAÇÕES LTDA. (2004). $\quad$ Fortaleza. Disponível em:<www.polymar.com.br/quitosana/quito-apli.htm>. Acesso em: 15 mar. 2004.

POPPOFF, M.Y. et al. (1995). Supplement 1994 (38) to the kauffman - white scheme. Research in Microbiology, Paris, v.146, n.9, p.799-803.

QI, L. et al. (2004). Preparation and antibacterial activity of chitosan nanoparticles. Carbohydrate Research, Amsterdam, v.339, n.16, p.26932700, Nov.

RAMADAN, A.M.J. (1997). Structural and biological aspects of copper (II) complexes with 2-methyl-3-amino-(3H0-quinazolin-4-one. Journal of Inorganic Biochemistry, New York, v.65, n.3, p.183-189, Feb.

RABEA, E.I. et al. (2003). Chitosan as antimicrobial agent: applications and mode of action. Biomacromolecules, Washington, v.4, n.6, p.1457-1465, Nov./ Dec.

RIVAS, L.G. et al. (2004). Selective antimicrobial action of chitosan against spoilage yeasts in mixed culture fermentations ind. Journal of Microbiology and Biotechnology, Korea, v.33, p.16-22.

ROBERTS, G.A.F. (1992). Chitin chemistry. London: Mac Millan Press.

ROLLER, S.; COVILL, N. (1999). The antifungal properties of chitosan in laboratory media and apple juice. International Journal of Food Microbiology, Amsterdam, v.47, n.1/2, p.67-77, Mar.

SALYERS, A.A.; WHITT, D.D. (1994). Salmonella infection. In: (Ed.). Bacterial pathogenesis: a molecular approach. Washington: ASM Press. p.294-243. 
SANTOS, J.E. et al (2003). Caracterização de quitosanas comerciais de diferentes origens. Polímeros: ciência e tecnologia, São Carlos, v.13, n.4, p.242-249, out./dez.

SASHIMA, H. et al. (1993). Enzimatic degradation of chitin and chitosan. In: MUZZARELLI, R.A.A. (Ed.). Chitin enzymology: grottammare (AP). Ancona: Alda Tecnografica. p.177-186.

SAWAYANAGI, Y.; NAMBU, N.; NAGAI, T. (1983). Pharmaceutical interactions in dosage form and processing. 38. Dissolution properties and bioavailability of phenytoin from ground mistures with chitin or chitosan. Chemical and Pharmaceutical Bulletin, Tokyo, v.31, n.6, p.2064-2068.

SEKIGUCHI, S. et al. (1994). Molecular weight dependency of antimicrobial activity by chitosan oligomers. In: NISHINARI, K.; DOI, E. (Ed.). Food hydrocolloids: structuress, properties and functions. New York: Plenum Press. p.71-76.

SHAHIDI, F.; ARACHCHI, J.K.V.; JEON, Y.J. (1999). Food applications of chitin and chitosans. Trends in Food Science \& Technology, Cambridge, v.10, n.2, p.37-51, Feb.

SHEPHERD, R.; READER, S.; FALSHAW, A. (1997). Chitosan functional properties. Glycoconjugate Journal, New York, v.14, n.4, p.535-542, Jan.

SIGNINI, R.; CAMPANA FILHO, S.P. (1998). Purificação e caracterização de quitosana comercial. Polímeros: ciência e tecnologia, São Paulo, v.4, p.63.

SIGNINI, R. (2002). Estudo das relações estruturas/propriedades de quitina e quitosana. 167p. Tese (Doutorado) - Instituto de Química de São Carlos, Universidade de São Paulo, São Carlos, 2002.

SILVA, C.H.P.M. (1999). Bacteriologia: um texto ilustrado.Teresópolis: Eventos. 
SIMON, G.L.; GORBACH, S.L. (1991). Normal alimentary tract microflora. In: BLASER, M.J. et al. (Ed.). Infections of gastrointestinal tract. New York: Raven Press.

SIMPSON, B.K. et al. (1997).Utilization of chitosan for preservation of raw shrimp (Pandalus bareali). Food Biotechnology, Philadelphia, v.11, n.1, p.2544.

SUDARSHAN, N.R.; HOOVER, D.G.; KNORR, D. (1992). Antibacterial action of chitosan. Food Biotechnology, Philadelphia, v.6, n.3, p.257-272.

TARSI, R. et al. (1998). Effect of low-molecular -weight chitosans on the adhesive properties of oral streptococci. Oral Microbiology and Immunology, Copenhagen, v.13, n.4, p.217-224, Aug.

TRABULSI, L.R. et al. (2004). Microbiologia. 4.ed. São Paulo: Atheneu.

TSAI, G.J.; SU, W.H. (1999). Antibacterial activity of shrimp chitosan against Escherichia coli. Journal of Food Protection, Ames, v.62, n.3, p.239-243, Mar.

TSAI, G.J. et al. (2002). Antimicrobial activit of shrimp chitin and chitosan from different treatments and applications of fish preservation. Fishieries Science, Tawan, v.68, n.1, p.170-177, Feb.

UCHIDA, Y.; IZUME, M.; OHTAKARA, A. (1989). Preparation of chitosan oligomers with purifiied chitosanase and its application. In: SKJAK- BRAEK, G.; ANTHONSEN, T.; SANDFORD, P. (Ed.). Chitin and chitosan: sources, chemistry, biochemistry, physical properties and applications. London: Elsevier. p.373-382.

VERONESI, R.; FOCACCIA, R.(1997). Tratado de Infectologia. São Paulo: Atheneu. 
XIE, W. et al. (2002). Preparation and antibacterial activity of a water- soluble chitosan derivative. Carbohydrate Polymers, Barking, v.50, n.1, p.35-40, Oct.

ZHENG, L.Y.; ZHU, J.F.. Study on antimicrobial activity of chitosan with different molecular weights. Carbohydrate Polymers, Barking, v.54, n.4, p.527-530, Dec.

WANG, G. (1992). Inhibition and inactivation of five species of foodborne pathogens by chitosan. Journal of Food Protection, Ames, v.55, n.11, p.916925, Nov.

WHO, expert committee on biological standardization. (1977). Genebra. Technical Report, Ser.nº 610.

WILCOX, C.M.; SCHWARTZ, D.A.; COTSONIS, E. (1996). Chronic unexplained diarrhea in human immunodeficiency virus infection: determination of the best diagnostic approach - reply. Gastroenterology, New York, v.111, n.1, p.270-271, July.

YOUNG, D.H.; KOHLE, H.; KAUSS, H. (1982). Effect of chitosan on membrane permeability of suspension - cultured Glycine maxand Phascolus vulgaris cells. Plant Physiology, Rockville, v.70, n.5, p.1449-1454, Nov.

YUN, Y.S.; KIM, K.S.; LEE, Y.N. (1999). Antibacterial and antifungal effect of chitosan. Journal and Chitin and Chitosan, Korea, v.4, p.8-14. 


\section{ANEXO}

\section{CONTROLE DE TURBIDEZ PARA A PREPARAÇÃO DO INÓCULO}

Para preparar a densidade do inóculo para um teste de sensibilidade, deve-se usar um controle de turbidez de $\mathrm{BaSO}_{4}$, equivalente a uma solução de McFarland 0,5 ou seu equivalente óptico( ex., suspensão de partículas de látex) A solução padrão de MacFarland 0,5 de $\mathrm{BaSO}_{4}$ pode ser preparada da seguinte maneira.

(1) Acrescenta-se uma alíquota de $0,5 \mathrm{~mL}$ de $\mathrm{BaCl}_{2}$ 0,048 mol/L ( 1,175\% w/v $\left.\mathrm{BaCl}_{2} .2 \mathrm{H}_{2} \mathrm{O}\right)$ a $99,5 \mathrm{~mL}$ de $\mathrm{H}_{2} \mathrm{SO}_{4} \quad 0,18 \mathrm{~mol} / \mathrm{L}(1 \% \mathrm{v} / \mathrm{v})$, homogeneizando constantemente para manter a suspensão.

(2) A densidade correta do controle de turbidez deve ser verificada usando um espectrofotômetro com fonte de luz de $1^{\text {' }} \mathrm{cm}$ e cubeta apropriada para determinar a absorbância. A absorbância da solução padrão de MacFarland a 0,5 deverá variar de 0,08 a 0,1 utilizando um comprimento de onda de $625 \mathrm{~nm}$.

(3) A suspensão de sulfato de bário deve ser transferida, em alíquotas de 4 a $6 \mathrm{~mL}$, para tubos com tampas de rosca do mesmo tamanho usados para cultivar e diluir inóculo bacteriano.

(4) Esses tubos devem ser selados hermeticamente e armazenados em local escuro, à temperatura ambiente.

(5) O controle de turbidez de sulfato de bário deve ser agitado vigorosamente num misturador mecânico tipo vórtex antes de cada uso, verificando se está uniformemente túrbido. No caso de partículas de látex devem ser misturados invertendo-as suavemente e não num misturador tipo vórtex.

(6) Os controles de sulfato de bário devem ser substituídos, ou suas densidades verificadas, todo mês.

NCCLS. Methods for Dilution Antimicrobial Susceptibility Tests for Bacteria That Grow Aerobically; Approved Standard- Sixth Edition. NCCLS DOCUMENT M7-A6 (ISBN 1-56238-486-4).NCCLS, 940 West Valley Road, Suite 1400, Wayne, Pennsylvania19087-1898USA,2003. 